\author{
Aus der Abteilung Allgemein- und Viszeralchirurgie \\ (Prof. Dr. med. H. Becker) \\ im Zentrum Chirurgie \\ der Medizinischen Fakultät der Universität Göttingen
}

\title{
Der Einfluss von NR3C1 und PDK4 auf das Wachstum kolorektaler Tumorzellen
}

\author{
INAUGURAL-DISSERTATION \\ zur Erlangung des Doktorgrades \\ der Medizinischen Fakultät \\ der Georg-August-Universität zu Göttingen \\ vorgelegt von \\ Stefanie Schmetzke \\ aus \\ Neuss
}

Göttingen 2012 
Dekan: Prof. Dr. med. C. Frömmel

I. Berichterstatter: Prof. Dr. med. BM. Ghadimi

II. Berichterstatter/in: Prof. Dr. med. Rüschoff

III. Berichterstatter/in: Prof. Dr. med. Oppermann

Tag der mündlichen Prüfung: 02.10.2012 


\section{Inhaltsverzeichnis}

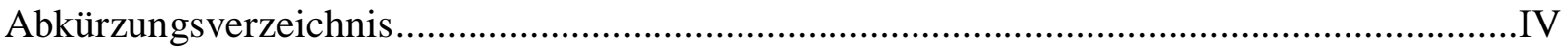

Abbildungsverzeichnis......................................................................................... VIII

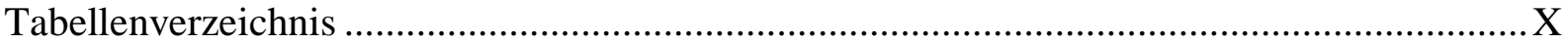

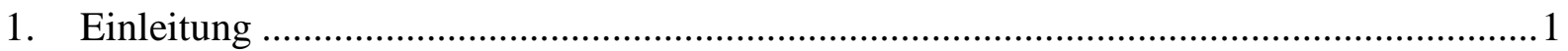

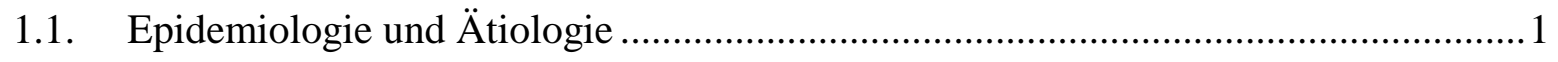

1.2. Lokalisation und Stadieneinteilung ................................................................. 1

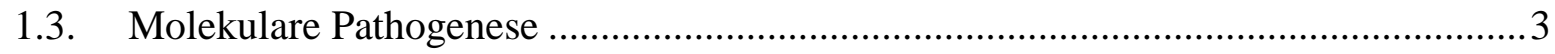

1.3.1. Genetische Instabilität............................................................................. 4

1.3.1.1. Chromosomale Instabilität..................................................................

1.3.1.2. Mikrosatelliteninstabilität............................................................... 6

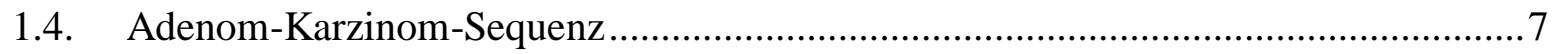

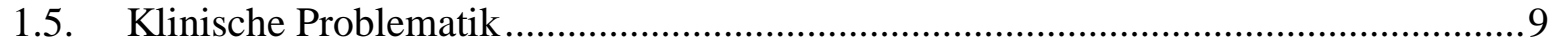

1.6. Zielsetzung und Fragestellung …........................................................... 10

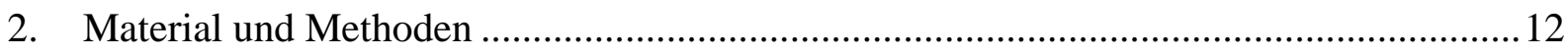

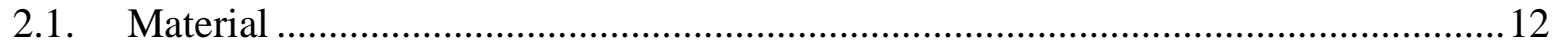

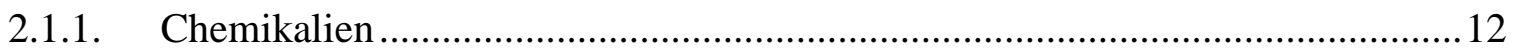

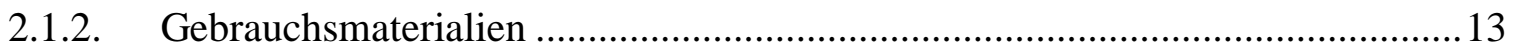

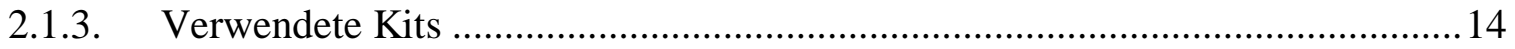

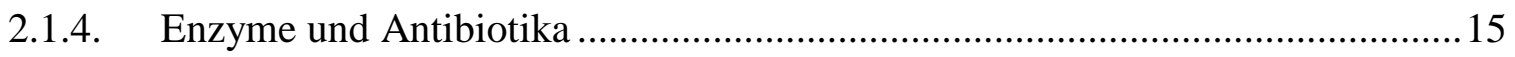

2.1.5. Zelllinien und Zellkulturreagenzien...................................................... 15

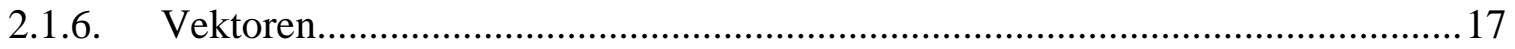

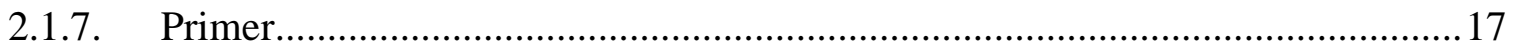

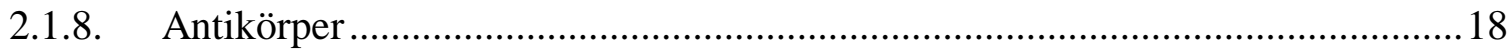

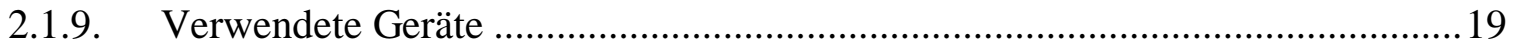

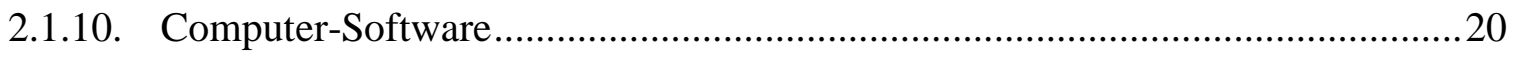

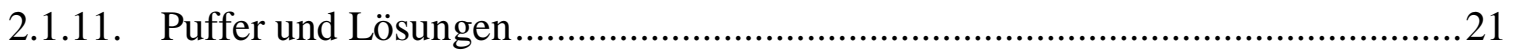

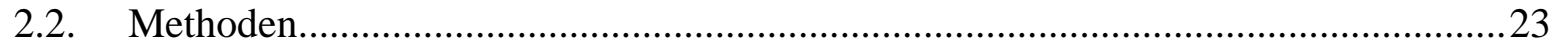

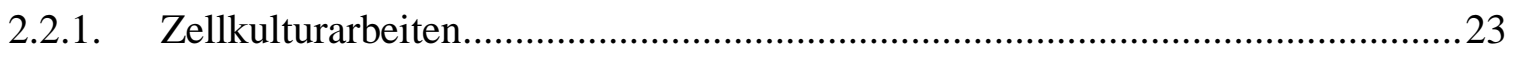




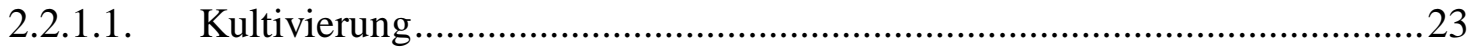

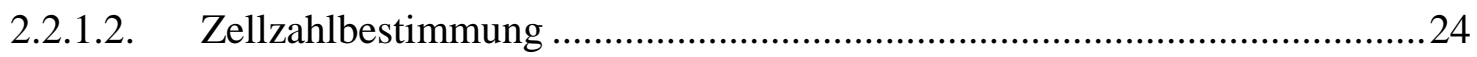

2.2.1.3. Auftauen und Einfrieren von Zellen.................................................. 24

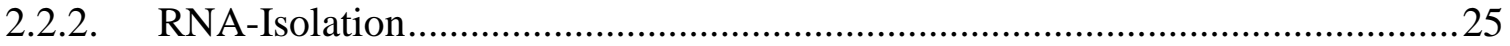

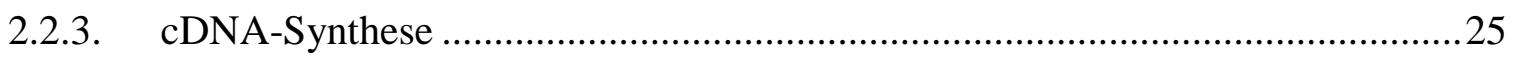

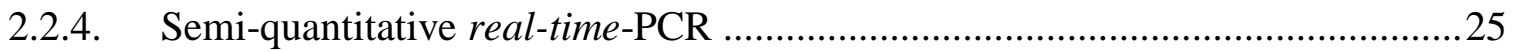

2.2.5. Erstellen, Linearisieren und Aufreinigen der Vektoren .................................27

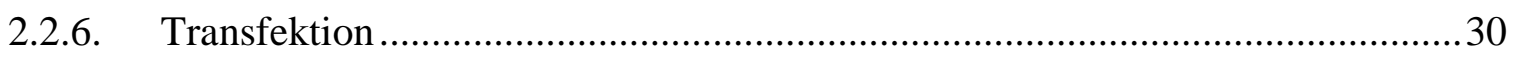

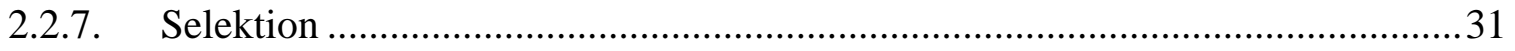

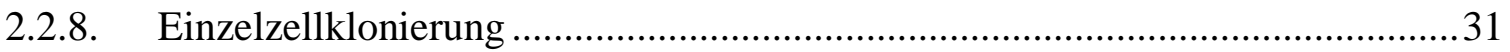

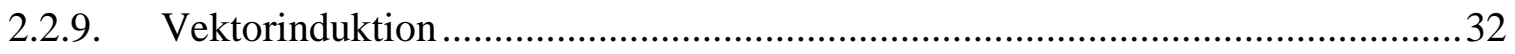

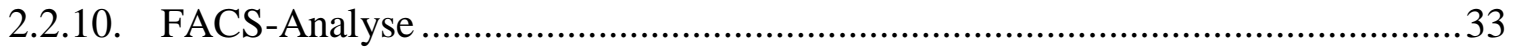

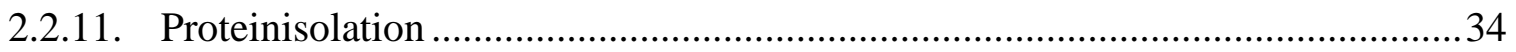

2.2.12. Proteinbestimmung nach Bradford und Probenvorbereitung ...........................34

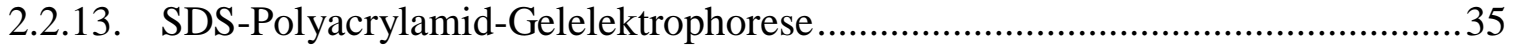

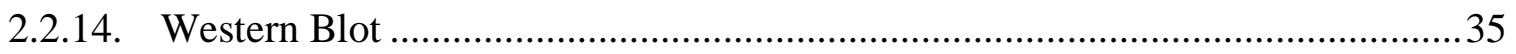

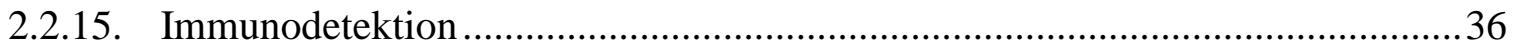

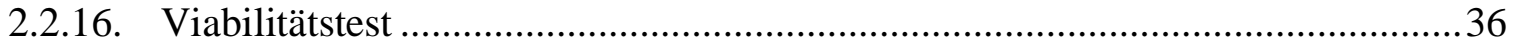

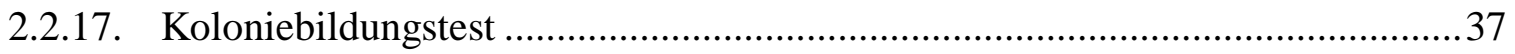

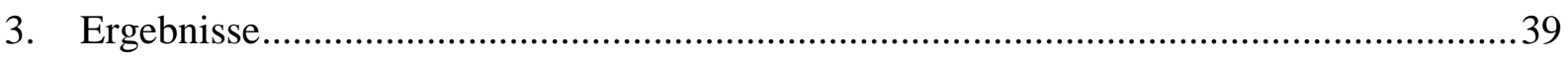

3.1. Genexpressionsanalysen kolorektaler Tumoren ...............................................39

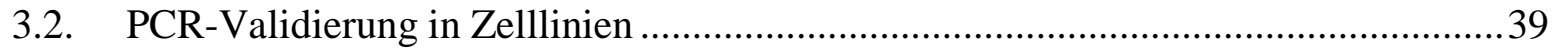

3.3. Herstellung von stabilen Zellklonen ...........................................................41

3.3.1. Bestimmung der Antibiotikakonzentrationen für die Selektion .......................41

3.3.2. Stabile Tet-Repressor-Expression in SW480 .............................................43

3.3.3. Herstellung von GFP-exprimierenden Zellen .............................................45

3.3.4. Herstellung von GR-überexprimierenden Zellen..........................................49

3.3.5. Herstellung von PDK4-überexprimierenden Zellen .......................................50

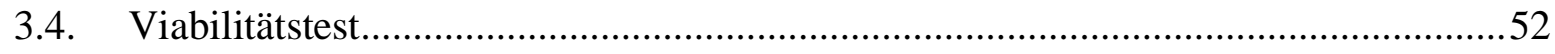

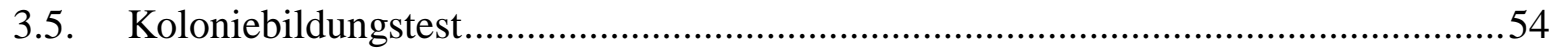




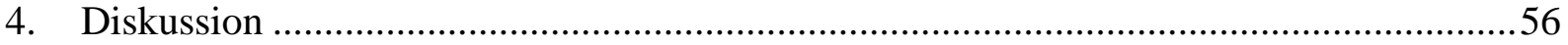

4.1. Genexpressionsanalysen kolorektaler Tumoren .................................................57

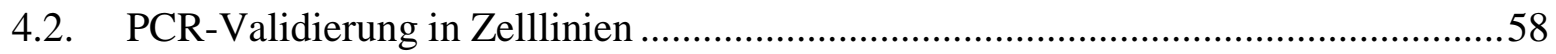

4.3. Beschreibung der Zielgene ..............................................................................5

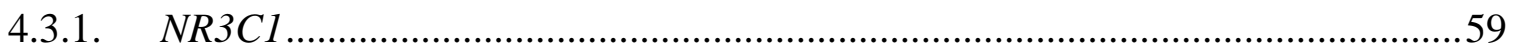

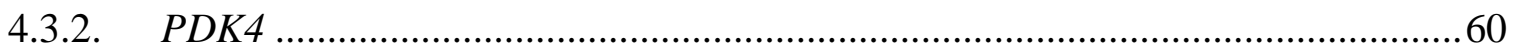

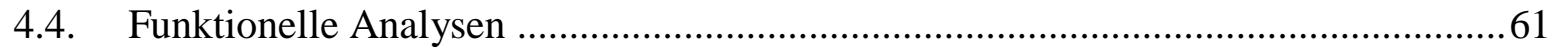

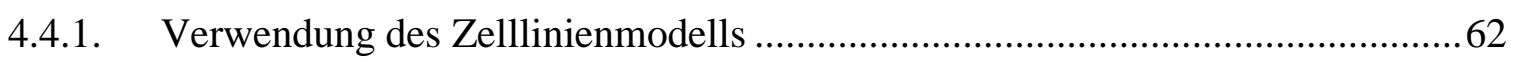

4.4.2. Etablierung von stabil überexprimierenden Zelllinien ......................................63

4.4.3. Viabilitätstest und Koloniebildungstest ............................................................65

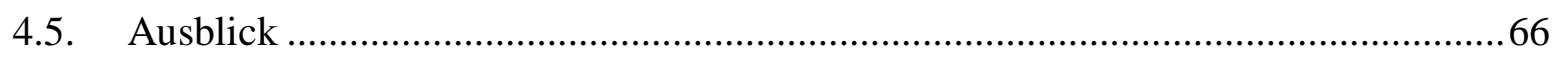

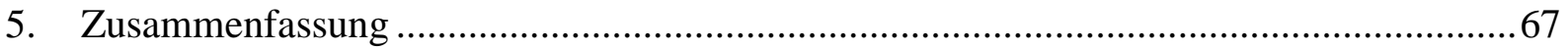

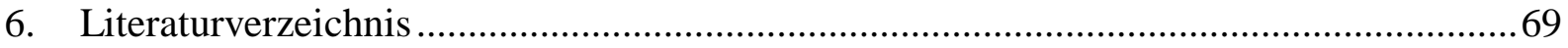




\section{Abkürzungsverzeichnis}

$\alpha-$

APC

APS

ATCC

BAX

BSA

CA5A

cDNA

CLCA4

CMV

$\mathrm{Ct}$

CTNNB1

$\mathrm{ddH}_{2} \mathrm{O}$

DMSO

DNA

DNase

DTT

EDTA

FACS

FAP

FBS

FBXL12

For

GAP
Antikörper

Adenomatous Polyposis Coli

Ammoniumpersulfat

American Type Culture Collection

B-Cell Lymphoma2-Associated X Protein

Bovines Serum-Albumin

Carbonic Anhydrase V

Complementary DNA

Chloride Channel Accessory 4

Zytomegalievirus

Cycle Threshold

Catenin (Cadherin-Associated Protein) Beta

double destilled water

Dimethylsulfoxid

Desoxyribonukleinsäure

Desoxyribonuklease

Dithiothreitol

Ethylendiamintetraessigsäure

Fluorescence Activated Cell Sorting

Familiäre Adenomatöse Polyposis

Fetales Kälberserum

F-box and Leucine-Rich Repeat Protein 12

Forward

GTPase aktivierendes Protein 
GDP

GFP

GR

GTP

$\mathrm{HCl}$

HIF

HNPCC

$\mathrm{KCl}$

$\mathrm{KH}_{2} \mathrm{PO}_{4}$

KRAS

MEM

MLH1

mRNA

MS4A12

MSH2

MSH6

$\mathrm{Na}_{2} \mathrm{HPO}_{4}$

$\mathrm{NaCl}$

$\mathrm{NaOH}$

NIH

NP-40

NR3C1

NUDT11

OTUB1

PBS
Guanosindiphosphat

Green Fluorescent Protein

Glukokortikoid-Rezeptor

Guanosintriphosphat

Salzsäure

Hypoxia Inducible Factor

Hereditäres nichtpolypöses Kolonkarzinomsyndrom

Kaliumchlorid

Kaliumdihydrogenphosphat

Kirsten Rat Sarcoma Viral Oncogene

Minimum Essential Medium Eagle

MutL Homolog 1

“messenger” Ribonukleinsäure

Membrane-Spanning 4-Domains, Subfamily A, Member 12

MutS Homolog 2

MutS Homolog 6

Dinatriumhydrogenphosphat

Natriumchlorid

Natriumhydroxid

National Institutes of Health

Nonidet P-40

Nuclear Receptor Subfamily 3, Group C, Member 1 (kodiert

für den Glukokortikoid-Rezeptor GR)

Nudix (Nucleoside Diphosphate Linked Moiety X)-Type

Motif 11

OTU domain, ubiquitin aldehyde binding 1

Phosphate Buffered Saline 
PBST

PCR

PDC

PDK4

$\mathrm{pH}$

PMS1

PMS2

PVDF

RAB35

Rev

RIN

RNA

RNAi

RPMI

RT

SDS

SDS-PAGE

SEM

SMAD2-4

TBS

TBST

TEMED

TGFBRII

TGF-ß

TP53
Phosphate Buffered Saline Tween

Polymerase-Ketten-Reaktion

Pyruvat-Dehydrogenase-Komplex

Pyruvat-Dehydrogenase-Kinase 4

Negativer dekadischer Logarithmus der $\mathrm{H}^{+}$-Ionen-

Konzentration

Postmeiotic Segregation Increased 1

Postmeiotic Segregation Increased 2

Polyvinylidenfluorid

RAB35, member RAS oncogene family

Reverse

RNA-Integritätsnummer

Ribonukleinsäure

RNA Interference

Roswell Park Memorial Institute

Raumtemperatur

Natriumdodecylsulfat

SDS-Polyacrylamid-Gelelektrophorese

Standard Error of the Mean

Mothers Against Decapentaplegic Homolog 2-4

Tris Buffered Saline

Tris Buffered Saline Tween

Tetramethylethylendiamin

Transforming Growth Factor-Beta Receptor II

Transforming Growth Factor-Beta

Tumor Protein 53 
Tris

tRNA

ü.N.

UICC

V

z.B.

${ }^{\circ} \mathrm{C}$

bp

$\mathrm{h}$, min, sec

kDa, Da

$\mathrm{kg}, \mathrm{g}, \mathrm{mg}, \mu \mathrm{g}$

$1, \mathrm{ml}, \mu \mathrm{l}$

$\mathrm{M}, \mathrm{mM}$

$\mathrm{Nm}$

rpm

$\mathrm{U}$

\section{Dekadische Vorsilben}

$\begin{array}{llll}\text { n (nano) } & 10^{-9} & \mathrm{G}(\text { giga }) & 10^{9} \\ \mu \text { (mikro) } & 10^{-6} & \mathrm{M} \text { (mega) } & 10^{6} \\ \text { m (milli) } & 10^{-3} & \mathrm{k}(\text { kilo }) & 10^{3} \\ \mathrm{c} \text { (zenti) } & 10^{-2} & \mathrm{~h} \text { (hekto) } & 10^{2} \\ \mathrm{~d} \text { (dezi) } & 10^{-1} & \mathrm{da}(\text { deka) } & 10^{1}\end{array}$

Tris(hydroxymethyl)aminomethan

„transfer" RNA

über Nacht

Union Internationale Contre le Cancer

Volumen

zum Beispiel

Grad Celsius

Basenpaare

Stunde, Minute, Sekunde

Kilodalton, Dalton

Kilogramm, Gramm, Milligramm, Mikrogramm

Liter, Milliliter, Mikroliter

Molar, Millimolar

Nanometer

Rounds per Minute (Runden pro Minute)

Unit (Einheit für Enzymaktivität) 


\section{Abbildungsverzeichnis}

Abbildung 1.1 Genetisches Progressionsmodell des kolorektalen Karzinoms $\quad$ Seite 7 nach Vogelstein

Abbildung 1.2 Schematische Darstellung des experimentellen Vorgehens Seite 11 dieser Arbeit

Abbildung 2.1 Struktur des (A) pcDNA6/TR- und (B) pT-REx-DEST31- Seite 27 Vektors

Abbildung 2.2 Schematische Darstellung der Funktionsweise des Tet- Seite 28 Repressors

Abbildung 2.3 Belegung der Sechs-Well-Platte für die Transfektion mit dem Seite 30 Vektor pT-REx-DEST31

Abbildung 2.4 Schematische Darstellung des Vorgehens bei der Seite 32 Einzelzellklonierung

Abbildung 2.5 Belegung der 96-Well-Platte für den Viabilitätstest Seite 37

Abbildung 2.6 Belegung der Sechs-Well-Platte für den Koloniebildungstest

Seite 38

Abbildung 3.1 Ermittlung der optimalen Antibiotikakonzentration für die Seite 42 Selektion von SW480 mit Blastizidin über sieben Tage

Abbildung 3.2 Ermittlung der optimalen Antibiotikakonzentration für die Seite 43 Selektion von SW480pcDNA6/TR mit Genetizin über sieben Tage

Abbildung 3.3 Die Tet-Repressor-Expression in den Einzelzellklonen 
Abbildung 3.4 Mikroskopische Aufnahmen der heterogenen GFP- Seite 46 transfizierten SW480pcDNA6/TR1.7-Zellen

Abbildung 3.5 FACS-Analyse der heterogenen GFP-transfizierten Seite 47 SW480pcDNA6/TR1.7-Zellen

Abbildung 3.6 Die GFP-Expression in den Einzelzellklonen

Seite 48

Abbildung 3.7 Die GR-Expression in den Einzelzellklonen

Seite 50

Abbildung 3.8 Die PDK4-Expression in den Einzelzellklonen

Seite 51

Abbildung 3.9 Viabilitätstest der Überexpressionsklone

Seite 53

Abbildung 3.10 Koloniebildungstest der Überexpressionsklone

Seite 55 


\section{Tabellenverzeichnis}

Tabelle 1.1 TNM-Klassifikation des kolorektalen Karzinoms

Seite 2

Tabelle $1.2 \quad$ UICC-Stadien des kolorektalen Karzinoms

Seite 3

Tabelle 2.1 Wachstumsbedingungen der verwendeten Zelllinien

Seite 16

Tabelle 2.2 PCR-Primer für die ausgewählten Gene

Seite 17

Tabelle 2.3 PCR-Primer für die Referenzgene

Seite 18

Tabelle 2.4

Primäre Antikörper mit verwendeter Konzentration und

Seite 18 Inkubationsbedingungen

Tabelle 2.5

Sekundäre Antikörper mit verwendeter Konzentration und

Seite 19 Inkubationsbedingungen

Tabelle 2.6 Zusammensetzung des achtprozentigen SDS-Gels

Seite 21

Tabelle 2.7 Reagenzien zum Linearisieren der Vektoren

Seite 29

Tabelle 3.1 Fold Changes der Genexpression im Mikroarray und der Seite 40 Validierungs-PCR 


\section{1. $\quad$ Einleitung}

\subsection{Epidemiologie und Ätiologie}

Das kolorektale Karzinom ist mit etwa 70.000 Neuerkrankungen pro Jahr die zweithäufigste Krebserkrankung in Deutschland. Die relative Fünf-Jahres-Überlebensrate beträgt zwischen $53 \%$ bis $63 \%$. Für beide Geschlechter stellt diese Erkrankung mit 12 bis $14 \%$ die zweithäufigste Krebstodesursache in Deutschland dar (Husmann et al. 2010).

Die Mehrzahl der kolorektalen Karzinome tritt sporadisch auf. Risikofaktoren sind Alter, männliches Geschlecht, Rauchen, Adipositas, Diabetes mellitus, chronisch entzündliche Darmerkrankungen, Kolonpolypen oder ein kolorektales Karzinom in der Anamnese und der Konsum von rotem Fleisch und Alkohol (Chan und Giovannucci 2010; Cunningham et al. 2010).

In $5 \%$ der Fälle liegt eine erbliche Erkrankung vor. Dazu gehören das hereditäre nichtpolypöse Kolonkarzinomsyndrom (HNPCC), die Familiäre Adenomatöse Polyposis (FAP) und seltenere Syndrome, wie z.B. das juvenile Polyposis-Syndrom und das PeutzJegher-Syndrom (Gala und Chung 2011).

\subsection{Lokalisation und Stadieneinteilung}

Kolorektale Karzinome sind zu insgesamt 50\% im Kolon lokalisiert. Davon liegen $60 \%$ im Colon sigmoideum und $20 \%$ im Coecum und dem Colon ascendens. Die restlichen $20 \%$ sind über das übrige Kolon verteilt. Ca. $50 \%$ der kolorektalen Karzinome sind im Rektum gelegen. Die Grenzmarke vom Rektum- zum Kolonkarzinom ist hierbei eine Distanz von $16 \mathrm{~cm}$ vom aboralen Tumorrand zur Anokutanlinie, gemessen mit dem starren Rektoskop (Herold 2010).

Die Stadieneinteilung des kolorektalen Karzinoms erfolgt am histopathologischen Präparat nach TNM-Klassifikation der Union Internationale Contre le Cancer (UICC). T steht für die Infiltrationstiefe des Primärtumors, $\mathrm{N}$ für die regionäre Lymphknotenmetastasierung 
und $M$ für die Fernmetastasierung. Aus der TNM-Klassifikation lässt sich das UICC-Stadium bestimmen, das sowohl für die Einschätzung der Prognose als auch für die Wahl des therapeutischen Vorgehens von Bedeutung ist (Puppa et al. 2010).

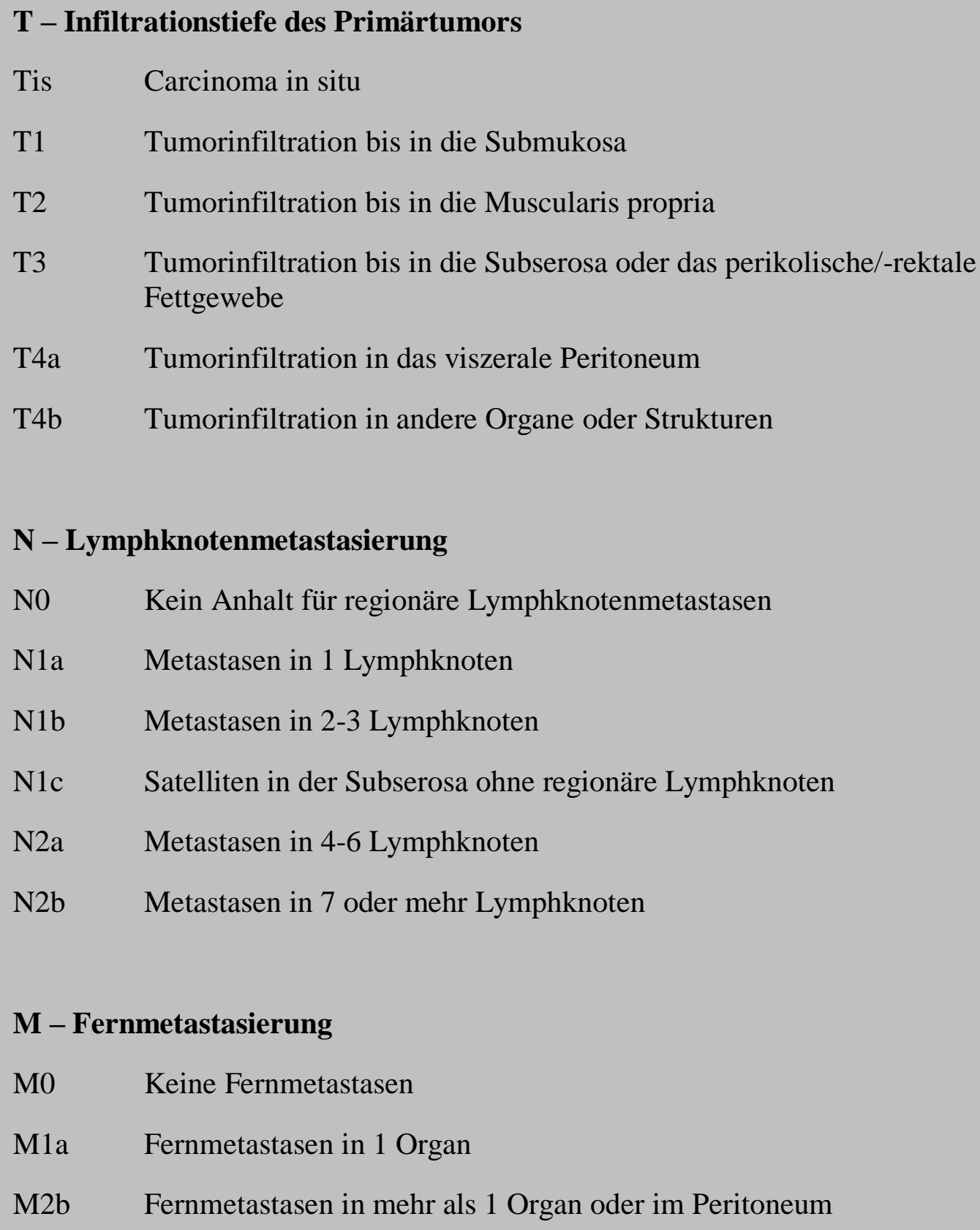




\begin{tabular}{llll|}
\hline \multirow{2}{*}{ UICC-Stadium } & \multicolumn{2}{l}{ TNM-Stadium } \\
I & Tis & N0 & M0 \\
IIA & T1, T2 & N0 & M0 \\
IIB & T3 & N0 & M0 \\
IIC & T4a & N0 & M0 \\
IIIA & T4b & N0 & M0 \\
& T1, T2 & N1a & M0 \\
IIIB & T1 & N2a & M0 \\
& T3, T4a & N1 & M0 \\
& T2, T3 & N2a & M0 \\
IVB & T1, T2 & N2b & M0 \\
IIIC & T4a & N2a & M0 \\
& T3, T4b & N2b & M0 \\
& T4b & N1, N2 & M0 \\
& N0-2 & M1a \\
& N0-2 & M1b \\
\hline
\end{tabular}

Tabelle 1.2: UICC-Stadien des kolorektalen Karzinoms (nach Edge et al. 2010)

\subsection{Molekulare Pathogenese}

Das kolorektale Karzinom ist eine komplexe polygenetische Erkrankung. Die Karzinogenese geht von einer gesunden Zelle aus, die durch genetische Veränderungen in Genen wie z.B. Onkogenen, Tumorsuppressorgenen und Mismatch-Repair-Genen einen Wachstumsvorteil erlangt (Calvert und Frucht 2002).

Onkogene entstehen durch die Mutation von sogenannten Protoonkogenen, die durch Signalübertragung die Zellvermehrung und das Zellwachstum steuern. Die Mutation eines 
der beiden Allele des Protoonkogens ist ausreichend, um das autonome Wachstum einer Zelle auszulösen (Bishop 1991).

Tumorsuppressorgene wirken negativ regulierend auf das Zellwachstum. Sie können die Apoptose von genetisch alterierten Zellen einleiten und schützen so die Zelle vor malignem Wachstum. Sie behindern die Expression von Onkogenen, vermindern die Aktivität ihrer Produkte und machen deren Effekte rückgängig (Marshall 1991). Nach der Two-HitHypothese von Knudson müssen beide Allele eines Tumorsuppressorgens inaktiviert sein, damit es seine wachstumshemmende Funktion verliert (Knudson 1971). Zum Verlust beider Allele kommt es durch zwei unabhängige Ereignisse, wie z.B. Punktmutationen, falsche Rekombination während der Mitose, sowie Verlust eines Chromosomenbruchstückes oder eines ganzen Chromosoms (Lengauer et al. 1998; Hanahan und Weinberg 2000).

Mismatch-Repair-Gene reparieren Basenfehlpaarungen und sind so für eine fehlerfreie DNA-Replikation während der Zellteilung verantwortlich. Durch Mutationen in beiden Allelen kommt es vermehrt zu Fehlern in der DNA des gesamten Genoms, die auch wachstumsregulierende Gene betreffen können (Calvert und Frucht 2002).

Durch das Auftreten einer Reihe solcher genetischen Veränderungen erlangt die Zelle unbegrenztes replikatives Potenzial, Fähigkeit zur vermehrten Angiogenese, Apoptoseresistenz, Unabhängigkeit von Wachstumssignalen, Unempfindlichkeit gegenüber Wachstumsinhibitoren und die Fähigkeit zu invasivem Wachstum bzw. Metastasierung. Zudem entwickelt die Zelle die Fähigkeit zur Umprogrammierung ihres EnergieMetabolismus sowie zur Umgehung der Kontrolle des Zellwachstums durch das Immunsystem. In Folge kommt es zu einer klonalen Zellvermehrung und malignem Wachstum (Hanahan und Weinberg 2000; Hanahan und Weinberg 2011).

\subsubsection{Genetische Instabilität}

Bei einem Großteil der Tumorarten sind mehrere Mutationen notwendig, um in einer gesunden Zelle ein malignes Wachstum auszulösen. Die Wahrscheinlichkeit einer Zelle, gleich mehrere Mutationen zu Lebzeiten zu erwerben, ist allerdings sehr gering. Deswegen 
wird davon ausgegangen, dass die präkanzeröse Zelle zunächst eine grundsätzliche genetische Instabilität entwickeln muss, sodass die Mutationsrate erhöht und hiermit die maligne Entartung der Zelle erleichtert wird (Loeb et al. 2003).

In der Tumorgenese kommt es sehr früh zur genetischen Instabilität. Der Zeitpunkt scheint sich während der Entstehung eines Adenoms vor der Progression zur Malignität zu befinden (Grady und Carethers 2008). Es wird vermutet, dass die genetische Instabilität selbst durch Mutationen von Genen entsteht, die an Prozessen wie der DNA-Reparatur und der Chromosomensegregation beteiligt sind und dadurch den Erwerb verschiedener Tumorassoziierter Mutationen fördern (Sieber et al. 2003).

Die genetische Instabilität wird in zwei Hauptgruppen unterteilt: die chromosomale Instabilität und die Mikrosatelliteninstabilität. Beide Gruppen werden im Folgenden genauer beschrieben.

\subsubsection{Chromosomale Instabilität}

In 80 bis $85 \%$ der kolorektalen Karzinome ist eine chromosomale Instabilität für die genetische Instabilität verantwortlich (Grady und Carethers 2008). Sie verursacht Änderungen in der Anzahl und der Struktur von Chromosomen. Der verantwortliche Mechanismus für eine chromosomale Instabilität ist allerdings noch nicht vollständig aufgeklärt (Pino und Chung 2010). Es wird vermutet, dass die Aneuploidie durch Mutationen in Genen entsteht, welche die Replikation bzw. Segregation der Chromosomen während der Mitose steuern oder den Zellzyklus kontrollieren und damit normalerweise Malignität verhindern. So können Fehler in der Kondensation der Chromosomen, in der Kohäsion der Schwesterchromatiden, in der Bildung oder Funktion der Zentrosomen und Mikrotubuli sowie des Spindelapparates zur chromosomalen Instabilität führen (Lengauer et. al 1998; Gollin 2005; Grady und Carethers 2008).

Mit der chromosomalen Instabilität sind zum Beispiel Mutationen wichtiger Tumorsuppressorgene wie adenomatous polyposis coli (APC), tumor protein 53 (TP53) und mothers against decapentaplegic homolog 4 (SMAD4) assoziiert, welche 
normalerweise Malignität verhindern, indem sie die chromosomale Stabilität während der Replikation bewahren (Markowitz und Bertagnolli 2009).

\subsubsection{Mikrosatelliteninstabilität}

Der Mikrosatelliteninstabilität-Signalweg ist für die Entstehung von etwa $15 \%$ der sporadischen kolorektalen Karzinome verantwortlich (Grady 2004). Die Ursache liegt in der Inaktivierung von Mitgliedern des Mismatch-Repair-Systems, die normalerweise Basenfehlpaarungen während der Replikation erkennen und die Reparatur einleiten (Migliore et al. 2011). Besonders anfällig für daraus entstehende Fehler sind sogenannte Mikrosatellitensequenzen. Das sind kurze repetitive Nukleotidsequenzen, die man sowohl in kodierenden als auch in nicht-kodierenden Bereichen des Genoms findet (Calvert und Frucht 2002). Mikrosatellitenabschnitte befinden sich zum Beispiel in den funktionellen Abschnitten von Genen, wie APC, B-cell lymphoma2-associated X protein $(B A X)$, catenin (cadherin-associated protein) beta (CTNNB1) und transforming growth factor, beta receptor II (TGFBRII), die in der Tumorgenese des kolorektalen Karzinoms eine wichtige Rolle spielen (Worthley et al. 2007; Perea et al. 2011). Durch die Akkumulation solcher Mutationen kann es zu einer malignen Entartung kommen. Im Gegensatz zur chromosomalen Instabilität bleibt die Diploidie bei mikrosatelliteninstabilen Zellen jedoch eher erhalten (Boland und Goel 2010).

Ein gehäuftes Auftreten von mikrosatelliteninstabilen Tumoren findet sich im hereditären nichtpolypösen Kolonkarzinomsyndrom. Diese Erkrankung ist für etwa $3 \%$ aller kolorektalen Karzinome mit Mikrosatelliteninstabilität verantwortlich (Hampel et al. 2005). In zwei Drittel der Fälle liegt eine Keimbahnmutation in mutL homolog 1 (MLHI) oder mutS homolog 2 ( $M S H 2$ ) Mutation vor, seltenere Mutationen betreffen die Gene mutS homolog 6 (MSH6), postmeiotic segregation increased 1 und 2 (PMS1 und PMS2) (Cunningham et al. 2010). Um einen Mismatch-Repair-Defekt auszulösen, ist nur noch eine somatische Mutation des zweiten Allels notwendig. Deshalb ist es besonders bei diesen Patienten sinnvoll, regelmäßige Koloskopien durchzuführen, um eine Entartung der Mukosa frühzeitig zu entdecken (Lynch und De La Chapelle 1999). 


\subsection{Adenom-Karzinom-Sequenz}

Das kolorektale Karzinom entsteht aus einer normalen kolorektalen Mukosazelle über das benigne Adenom bis hin zum malignen Adenokarzinom. Fearon und Vogelstein zeigten 1990, dass die verschiedenen morphologischen Entwicklungsstadien des kolorektalen Karzinoms mit bestimmten genetischen Veränderungen korrelieren. Durch die Akkumulation dieser Mutationen kann die Zelle unbegrenzt wachsen und proliferieren. Dieser Vorgang wird durch das genetische Progressionsmodell beschrieben (Fearon und Vogelstein 1990, siehe Abbildung 1.1).

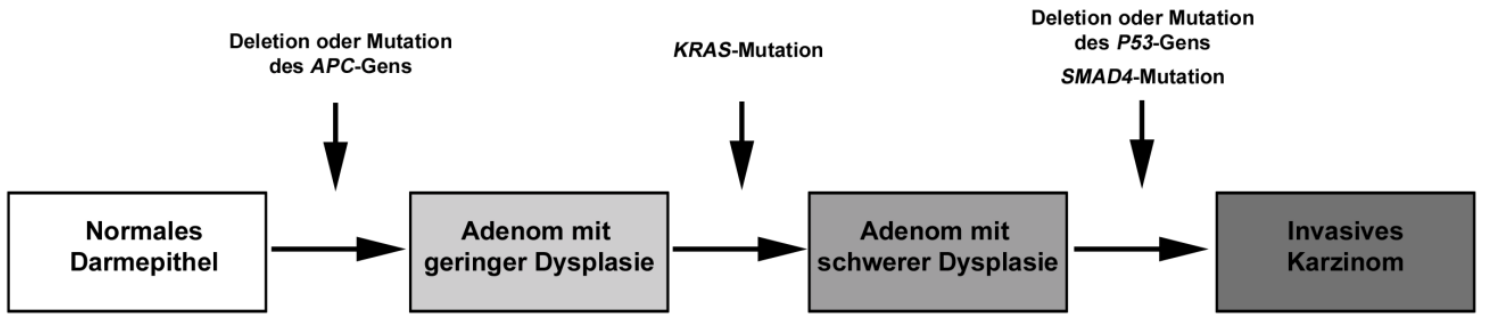

Abbildung 1.1: Genetisches Progressionsmodell des kolorektalen Karzinoms nach Vogelstein

Diese Abbildung zeigt die beschriebenen genetischen Veränderungen, die im Verlauf der kolorektalen Karzinogenese auftreten können (nach Fearon und Vogelstein 1990).

Das initiale und gleichzeitig häufigste Ereignis der Adenom-Karzinom-Sequenz ist eine inaktivierende Mutation oder Deletion des $A P C$-Gens. Dieses Tumorsuppressorgen ist verantwortlich für den proteosomalen Abbau und die Degradierung von nukleärem ß-Catenin, einem Ko-Transkriptions-Faktor von Genen, die den Zellzyklus beeinflussen. Aufgrund der Mutation des $A P C$-Gens kommt es zu einer Anhäufung von B-Catenin im Zellkern und dadurch zu einer Deregulation der epithelialen Homöostase der kolorektalen Mukosa (Alberici und Fodde 2006). APC ist außerdem verantwortlich für die regelrechte Anordnung und Aufteilung der Chromosomen während der Mitose. Es wird vermutet, dass eine $A P C$-Mutation somit $\mathrm{zu}$ einer chromosomalen Instabilität beisteuern kann (Worthley et al. 2007). 
$A P C$-Mutationen treten bei den meisten sporadischen kolorektalen Karzinomen auf. Sie spielen aber auch bei einer angeborenen kolorektalen Erkrankung, der Familiären Adenomatösen Polyposis (FAP), eine wichtige Rolle (Fearon 2011). Die FAP ist für etwa $1 \%$ aller kolorektalen Karzinome verantwortlich und entsteht durch die Keimbahnmutation eines Allels des $A P C$-Gens. Um eine $A P C$-Mutation auszulösen, ist nur noch die somatische Mutation eines Allels notwendig (Rustgi 2007). Im Kolon dieser Patienten wachsen Hunderte bis Tausende Polypen, welche im frühen Erwachsenenalter mit nahezu hundertprozentiger Wahrscheinlichkeit $\mathrm{zu}$ einem kolorektalen Karzinom entarten (Galiatsatos und Foulkes 2006).

KRAS (Kirsten rat sarcoma viral oncogene) ist ein Guanosintriphosphat (GTP) bindendes Protein, das bei Aktivierung wachstumsstimulierende Signale sendet. Durch die Wirkung des Enzyms GTPase aktivierendes Protein (GAP) hydrolysiert eine intrinsische GTPase GTP zu Guanosindiphosphat (GDP) und KRAS wird inaktiviert. Das mutierte KRAS reagiert weniger sensibel auf die Wirkung von GAP und führt so zu einer Dauerstimulation der Zelle mit Wachstumshormonen (Arends 2000; Leslie et al. 2002). Da sich bereits in vielen Adenomen KRAS-Mutationen finden lassen, vermutet man, dass es sich um ein relativ frühes Ereignis in der Karzinogenese handelt (Leslie et al. 2002).

SMAD4 wirkt gemeinsam mit SMAD2 und SMAD3 als intrazellulärer Mediator im Transforming-Growth-Factor-Beta (TGF- $\beta$ )-Signalweg (Takayama 2006; Fearon 2011). TGF- 3 ist ein negativer Wachstumsfaktor für zelluläre Differenzierung und Integrität. Durch eine SMAD4-Mutation wird die durch TGF-ß vermittelte Regulation aufgehoben (Lampropoulos et al. 2012). Die SMAD4-Mutation ist außerdem mit dem juvenilen Polyposis-Syndrom assoziiert, einer autosomal dominant vererbten Erkrankung, die für gastrointestinale Polypen und Tumoren prädestiniert (Bellam und Pasche 2010).

TP53 wird durch zellulären Stress, DNA-Schäden und Signale von Onkogenen aktiviert. Als sogenannter „Wächter des Genoms“ ist es verantwortlich für die Reparatur von DNASchäden, den Zellzyklusarrest und die Apoptose. Im Fall einer Schädigung des Genoms wirkt TP53 als Transkriptionsfaktor, der die Expression von Genen erhöht, die den Zellzyklus verlangsamen. Dadurch wird die nötige Zeit für die Reparatur der DNA geschaffen. Kann der Schaden nicht mehr repariert werden, wird die Apoptose induziert (Mills 2005; Efeyan und Serrano 2007). Im kolorektalen Karzinom ist die P53-Mutation 
meist mit dem Übergang von großen Adenomen in invasive Karzinome verbunden (Baker et al. 1990).

\subsection{Klinische Problematik}

Trotz großer Fortschritte in Diagnostik und Therapie des kolorektalen Karzinoms nimmt die altersstandardisierte Sterberate an dieser Erkrankung seit 1985 in den westlichen Ländern nur langsam ab, während die Erkrankungsrate in den letzten Jahren stetig ansteigt (Husmann et al. 2010). Nur etwa $59 \%$ der Patienten weltweit überleben die nächsten zehn Jahre nach Diagnosestellung (American Cancer Society 2010).

Bisher wurden die Prognose und das therapeutische Vorgehen anhand von histopathologischen Parametern mit der TNM-Klassifikation festgelegt. Doch die Histopathologie alleine reflektiert nicht die gesamte Tumorbiologie. Denn auch Tumoren mit ähnlicher Morphologie können sehr verschiedene Verläufe zeigen und unterschiedlich auf die Therapie ansprechen (Ladanyi et al. 2001).

Kolorektale Karzinome entstehen auf genetischer Basis. Aufgrund dessen ist das Verständnis der molekularen Vorgänge in der Entstehung und der Progression des kolorektalen Karzinoms von besonderer Bedeutung. Es legt den Grundbaustein für die Entwicklung neuer und innovativer Therapieansätze in der Behandlung von kolorektalen Tumoren. Durch die genauere Charakterisierung von kolorektalen Karzinomen könnte der Patient in Zukunft eine individuelle und auf sein genetisches Profil angepasste Therapie erhalten (Hernandez et al. 2000; Galizia et al. 2004). 


\subsection{Zielsetzung und Fragestellung}

In einer vorangegangenen Untersuchung unserer Arbeitsgruppe wurde die Genexpression zwischen Tumor und Mukosa in 73 Proben primärer Kolonkarzinome und 30 Proben gesunder Mukosa verglichen. Hierbei wurden 1950 Gene identifiziert, die zwischen Tumor und Mukosa hochsignifikant dereguliert waren $(\mathrm{P}<1 \mathrm{e}-7) .1582$ Gene waren im Tumor im Vergleich mit der Mukosa hochreguliert, die restlichen 368 Gene zeigten eine verminderte Expression (Grade et al. 2007). Aus einer solchen Menge differenziell exprimierter Gene klinisch interessante Zielgene zu identifizieren, stellt eine große Herausforderung dar. Zwar repräsentieren die Mikroarray-Daten ein molekulares Profil des kolorektalen Karzinoms, doch die Bedeutung einzelner identifizierter Gene für die Pathogenese dieser Erkrankung kann dadurch noch nicht geklärt werden. Ein möglicher Lösungsansatz für dieses Problem ist die Modulation der Genexpression im Zelllinienmodell, die eine Grundlage für die funktionelle Validierung in vitro schafft (Williams et al. 2003; Grade et al. 2011).

Diese Arbeit beschäftigt sich mit den Genen, die nach der oben genannten Studie im kolorektalen Karzinom herunter reguliert sind. Dabei wird von der Hypothese ausgegangen, dass die verminderte Expression dieser Gene dem Tumor einen Proliferations- oder Wachstumsvorteil verschafft. Ziel dieser Arbeit ist es, diese Hypothese im Zellinienmodell zu validieren und somit Gene zu identifizieren, welche einen direkten Einfluss auf das Überleben von kolorektalen Tumorzellen haben, wodurch sie prognostisch und therapeutisch relevant werden können.

Hierzu werden zunächst Gene, die in primären Kolonkarzinomen im Vergleich zur Mukosa herunter reguliert sind, mithilfe der semi-quantitativen real-time-Polymerase-KettenReaktion (PCR) in kolorektalen Tumorzelllinien validiert. Nachfolgend sollen Gene ausgewählt werden, welche das Mikroarray-Ergebnis bestätigen und sich durch Literaturrecherche als potentiell interessant erweisen. Diese sollen dann in einer kolorektalen Tumorzellinie überexprimiert werden. Nach der Transfektion wird eine Einzelzellklonierung durchgeführt, um Klone zu etablieren, die den Genvektor an der gleichen Stelle im Genom eingebaut haben. Die Klone mit der stärksten Genexpression 
sollen anschließend für funktionelle Analysen verwendet werden. Das experimentelle Vorgehen dieser Arbeit ist in Abbildung 1.2 schematisch dargestellt.

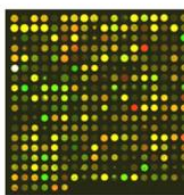

MikroarrayGenexpressionsanalyse Tumor vs. Mucosa

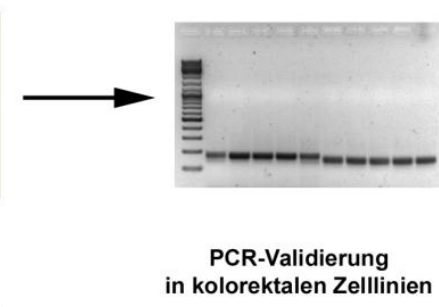

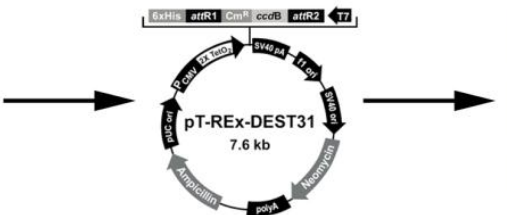

stabile Überexpression interessanter Gene in Zelllinien

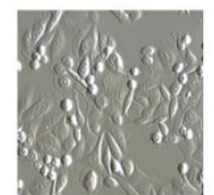

funktionelle Analysen mit den transfizierten Zellen

Abbildung 1.2: Schematische Darstellung des experimentellen Vorgehens dieser Arbeit

Folgende Fragen sollen beantwortet werden:

- Lässt sich die im Primärtumor nachgewiesene verminderte Expression definierter Gene auch in kolorektalen Tumorzelllinien validieren (mithilfe der semiquantitativen real-time-PCR)?

- Gelingt eine stabile Expression ausgewählter Gene in einer kolorektalen Tumorzelllinie?

- Hat dann die Überexpression dieser Gene einen Einfluss auf die Viabilität kolorektaler Tumorzellen sowie deren Fähigkeit, Kolonien zu bilden? 


\section{Material und Methoden}

\subsection{Material}

\subsubsection{Chemikalien}

10 mM dNTP Mix

Ammoniumpersulfat (APS)

Bovines Serum-Albumin (BSA)

Bromphenolblau

CellTiter-Blue ${ }^{\circledR}$ Cell Viability Assay

Dinatriumhydrogenphosphat $\left(\mathrm{Na}_{2} \mathrm{HPO}_{4}\right)$

Dithiothreitol (DTT)

Essigsäure

Ethanol, $99 \%$

Ethylendiamintetraessigsäure (EDTA)

GelRed, 10.000x

Glycin

$\mathrm{iQ}^{\mathrm{TM}}$ SYBR Green Supermix

Isopropanol

Kaliumchlorid $(\mathrm{KCl})$

Kaliumdihydrogenphosphat $\left(\mathrm{KH}_{2} \mathrm{HPO}_{4}\right)$

Kristallviolett

Magic Mark ${ }^{\mathrm{TM}}$ Standard

Methanol, $99 \%$
Invitrogen, Darmstadt, Deutschland

AppliChem, Darmstadt, Deutschland

Sigma, Steinheim, Deutschland

Roth, Karlsruhe, Deutschland

Promega, Mannheim, Deutschland

Merck, Darmstadt, Deutschland

AppliChem, Darmstadt, Deutschland

Roth, Karlsruhe, Deutschland

Roth, Karlsruhe, Deutschland

QualityBiological, Gaithersburg, MD, USA

Biotium, Köln, Deutschland

Sigma, Steinheim, Deutschland

BioRad, München, Deutschland

AppliChem, Darmstadt, Deutschland

Merck, Darmstadt, Deutschland

Merck, Darmstadt, Deutschland

Merck, Darmstadt, Deutschland

Invitrogen, Darmstadt, Deutschland

Roth, Karlsruhe, Deutschland 
Natriumchlorid $(\mathrm{NaCl})$

Natriumdodecylsulfat (SDS) $10 \%$

Natriumhydroxid Lösung $(\mathrm{NaOH})$

Nonidet P-40 (NP-40)

NuPage LDS Probenpuffer (4x)

NuPage MES SDS Laufpuffer

NuPAGE Novex 4-12 \% Bis-Tris Midi Gel

Proteo Block, Protease-Inhibitor

RNaseOUT $^{\mathrm{TM}}$

Roti ${ }^{\circledR}$ phorese Gel30

Roti ${ }^{\circledR}$ Quant

Salzsäure $(\mathrm{HCl})$

Spectra Broad Range Protein Ladder

Tetramethylethylendiamin (TEMED)

Tris(hydroxymethyl-)aminomethan

Trockenmilch

Tween20

UltraPure Agarose

$\beta$-Mercaptoethanol
Roth, Karlsruhe, Deutschland

AppliChem, Darmstadt, Deutschland

Merck, Darmstadt, Deutschland

AppliChem, Darmstadt, Deutschland

Invitrogen, Darmstadt, Deutschland

Invitrogen, Darmstadt, Deutschland

Invitrogen, Darmstadt, Deutschland

Fermentas, St. Leon-Rot, Deutschland

Invitrogen, Darmstadt, Deutschland

Roth, Karlsruhe, Deutschland

Roth, Karlsruhe, Deutschland

Merck, Darmstadt, Deutschland

Fermentas, St. Leon-Rot, Deutschland

AppliChem, Darmstadt, Deutschland

AppliChem, Darmstadt, Deutschland

Roth, Karlsruhe, Deutschland

Sigma, Steinheim, Deutschland

Invitrogen, Darmstadt, Deutschland

Roth, Karlsruhe, Deutschland

\subsubsection{Gebrauchsmaterialien}

15- und 50-ml-Röhrchen

Sechs-Well-Platten, 24-Well-Platten
BD Falcon, Heidelberg, Deutschland

Greiner Bio-One, Solingen, Deutschland 
96-Well-Platten

96-Well-Platten, Schwarz, für Photometrie Amersham Hybond ${ }^{\mathrm{TM}}-\mathrm{P}$

Cell Scraper

Einzelzellfilter

Eppendorf-Cup

FACS-Röhrchen

Filter $0,2 \mu \mathrm{m}$ steril

Filterpapier

Flüssigkeitsreservoirs

Kryoröhrchen

Neubauer-Zählkammer

Perfusorspritzen

Pipetten

Reaktionsgefäße

Transferpipetten

Zellkulturflaschen

Zentrifugationsröhrchen
TPP, Trasadingen, Schweiz

Corning, Amsterdam, Niederlande

GE Healthcare Limited, Buckinghamshire, UK

TPP, Trasadingen, Schweiz

BD, Franklin Lakes, NJ, USA

Eppendorf, Hamburg, Deutschland

BD, Franklin Lakes, NJ, USA

Whatman, Kent, Großbritannien

Whatman, Kent, Großbritannien

Roth, Karlsruhe, Deutschland

NALGENE, Rochester, NY, USA

Brand, Wertheim, Deutschland

Braun, Melsungen, Deutschland

Sarstedt, Nümbrecht, Deutschland

Eppendorf, Hamburg, Deutschland

Sarstedt, Nümbrecht, Deutschland

Sarstedt, Nümbrecht, Deutschland

Sarstedt, Nümbrecht, Deutschland

\subsubsection{Verwendete Kits}

Amaxa Nucleofector ${ }^{\circledR}$ Kit (Kit V)

Amersham $^{\mathrm{TM}}$ ECL Advance ${ }^{\mathrm{TM}}$ Western GE Healthcare Limited, Buckinghamshire, 
Blotting Detection Kit

MycoAlert $\left.^{(}\right)$Mycoplasma Detection Kit

QIAEX $^{\circledR}$ II Gel Extraction Kit

QuantiTectTM SYBR ${ }^{\circledR}$ Green RT-PCR Kit

RNeasy Mini Kit

\subsubsection{Enzyme und Antibiotika}

AhdI

DNase

SuperScript ${ }^{\circledR}$ II

Blastizidin

Genetizin (G-418)

Tetrazyklin
UK

Lonza, Köln, Deutschland

Qiagen, Hilden, Deutschland

Qiagen, Hilden, Deutschland

Qiagen, Hilden, Deutschland
New England Biolabs, Ipswich, MA, USA

Qiagen, Hilden, Deutschland

Invitrogen, Darmstadt, Deutschland

Roth, Karlsruhe, Deutschland

Roth, Karlsruhe, Deutschland

Roth, Karlsruhe, Deutschland

\subsubsection{Zelllinien und Zellkulturreagenzien}

$0,25 \%$ Trypsin-EDTA

Dimethylsulfoxid (DMSO)

Fetales Kälberserum (FBS)

Leibovitz's L-15 Medium

L-Glutamin

McCoy's Medium
Invitrogen, Darmstadt, Deutschland

Sigma-Aldrich, Steinheim, Deutschland

Pan, Aidenbach, Deutschland

Invitrogen, Darmstadt, Deutschland

BioWhittaker, Verviers, Belgien

Invitrogen, Darmstadt, Deutschland 
Minimum Essential Medium Eagle (MEM)

PBS pH 7,2

Roswell Park Memorial Institute (RPMI)- Invitrogen, Darmstadt, Deutschland 1640 Medium

Trypanblau

Zelllinie Caco-2

Zelllinie HT-29

Zelllinie LS513

Zelllinie SW1116

Zelllinie SW480
Sigma-Aldrich, Steinheim, Deutschland Invitrogen, Darmstadt, Deutschland

Merck, Darmstadt, Deutschland

ATCC, Manassas, VA, USA

ATCC, Manassas, VA, USA

ATCC, Manassas, VA, USA

ATCC, Manassas, VA, USA
ATCC, Manassas, VA, USA

\begin{tabular}{|c|c|}
\hline Zelllinie & Medium \\
\hline SW480 & L15 \\
\hline \multirow{2}{*}{ SW1116 } & $10 \% \mathrm{FBS}$ \\
\hline & $1 \%$ L- Glutamin \\
\hline \multirow{3}{*}{ Caco-2 } & MEM \\
\hline & $20 \% \mathrm{FBS}$ \\
\hline & $1 \%$ L- Glutamin \\
\hline \multirow{3}{*}{ LS513 } & RPMI-1640 \\
\hline & $10 \%$ FBS \\
\hline & $1 \%$ L- Glutamin \\
\hline \multirow{3}{*}{ HT-29 } & McCoy's \\
\hline & $10 \% \mathrm{FBS}$ \\
\hline & $1 \%$ L- Glutamin \\
\hline
\end{tabular}

Tabelle 2.1: Wachstumsbedingungen der verwendeten Zelllinien (gemäß den Empfehlungen der American Type Culture Collection, ATCC) 


\subsubsection{Vektoren}

pcDNA6/TR

pT-REx-DEST31
Invitrogen, Darmstadt, Deutschland

Invitrogen, Darmstadt, Deutschland

\subsubsection{Primer}

\begin{tabular}{|c|c|c|c|c|}
\hline Name & Sense & Exon & Sequenz & Amplikon \\
\hline \multirow{2}{*}{$C A 5 A$} & For & 1 & 5'TGGCAAACCAGCAATAACAC3' & \multirow{2}{*}{136 bp } \\
\hline & Rev & 2 & 5'GAGACCCTGAGTGGCTTCAG3' & \\
\hline \multirow{2}{*}{$N R 3 C 1$} & For & 6 & 5'GAAATGGGCAAAGGCAATAC3' & \multirow{2}{*}{$101 \mathrm{bp}$} \\
\hline & Rev & 7 & 5'CCCAGAGCAAATGCCATAAG3' & \\
\hline \multirow{2}{*}{ NUDT11 } & For & 1 & 5'AAACTAAAGCTGGGCGGTTC3' & \multirow{2}{*}{$131 \mathrm{bp}$} \\
\hline & Rev & 2 & 5'TGATCACTGGGTTCACATCAA3' & \\
\hline \multirow{2}{*}{$P D K 4$} & For & 1 & 5'GAGAGGTGGAGCATTTCTCG3' & \multirow{2}{*}{142 bp } \\
\hline & Rev & 2 & 5'CAGAATGTTGGCGAGTCTCA3' & \\
\hline \multirow{2}{*}{ CLCA4 } & For & 3 & 5'AATGTGGAGAGAAAGGCGAAT3' & \multirow{2}{*}{$107 \mathrm{bp}$} \\
\hline & $\operatorname{Rev}$ & 4 & 5'GAGCCCACTCATGGACAAAC3' & \\
\hline \multirow{2}{*}{$M S 4 A 12$} & For & 5 & 5'TTGGAGTGATTCTGCTGCTG3' & \multirow{2}{*}{139 bp } \\
\hline & Rev & 6 & 5'TGTGGCACAAGCTACGAAGA3' & \\
\hline
\end{tabular}

Tabelle 2.2: PCR-Primer für die ausgewählten Gene

For $=$ Forward, Rev $=$ Reverse, $b p=$ Basenpaare 


\begin{tabular}{lllll}
\hline Name & Sense & Exon & Sequenz & Amplikon \\
\hline \multirow{2}{*}{ FBXL12 } & For & 1 & 5'CATGTCGACCTGACGCTCTA 3' & \\
& Rev & 2 & 5'TGGGAGCCAGAGAACAGGTA3' & $118 \mathrm{bp}$ \\
\hline RAB35 & For & 1 & 5'AGATGGGCATCCAGTTGTTC3' & \\
& Rev & 2 & 5'GCCAGGTTGTCTTTCTTTGC3' & $108 \mathrm{bp}$ \\
\hline OTUB1 & For & 3 & 5'ATTGCTGTGCAGAACCCTCT3' & \\
& Rev & 4 & 5'GGTCTTGCGGATGTACGAGT3' & \\
\hline
\end{tabular}

Tabelle 2.3: PCR-Primer für die Referenzgene

For $=$ Forward, Rev $=$ Reverse, bp $=$ Basenpaare

\subsubsection{Antikörper}

\begin{tabular}{|c|c|c|c|}
\hline & Hersteller & Konzentration & $\begin{array}{l}\text { Inkubations- } \\
\text { Bedingungen }\end{array}$ \\
\hline $\begin{array}{l}\alpha \text {-Actin, Kaninchen, } \\
\text { monoklonal }\end{array}$ & $\begin{array}{l}\text { Sigma, Steinheim, } \\
\text { Deutschland }\end{array}$ & $\begin{array}{l}\text { 1:1.000 in } 5 \% \text { Milch- } \\
\text { PBS }\end{array}$ & $2 \mathrm{~h}, \mathrm{RT}$ \\
\hline $\begin{array}{l}\alpha \text {-His, Kaninchen, } \\
\text { polyklonal }\end{array}$ & $\begin{array}{l}\text { Cell Signaling, Danvers, } \\
\text { MA, USA }\end{array}$ & $\begin{array}{l}1: 1.000 \text { in } 5 \% \text { BSA- } \\
\text { TBST }\end{array}$ & ü.N., $4^{\circ} \mathrm{C}$ \\
\hline $\begin{array}{l}\alpha \text {-GR, Kaninchen, } \\
\text { polyklonal }\end{array}$ & $\begin{array}{l}\text { Abcam, Cambridge, } \\
\text { MA, USA }\end{array}$ & $\begin{array}{l}1: 2.000 \text { in } 5 \% \text { Milch- } \\
\text { TBST }\end{array}$ & ü.N., $4{ }^{\circ} \mathrm{C}$ \\
\hline $\begin{array}{l}\alpha-P D K 4, \text { Kaninchen, } \\
\text { polyklonal }\end{array}$ & $\begin{array}{l}\text { Abcam, Cambridge, } \\
\text { MA, USA }\end{array}$ & $\begin{array}{l}1: 2.500 \text { in } 3 \% \text { BSA- } \\
\text { TBST }\end{array}$ & 2h, RT \\
\hline $\begin{array}{l}\alpha-\text {-TetR, Maus, } \\
\text { monoklonal }\end{array}$ & $\begin{array}{l}\text { Clontech, Mountain } \\
\text { View, CA, USA }\end{array}$ & $\begin{array}{l}1: 1.000 \text { in } 5 \% \text { Milch- } \\
\text { PBS }\end{array}$ & 2h, RT \\
\hline
\end{tabular}

Tabelle 2.4: Primäre Antikörper mit verwendeter Konzentration und Inkubationsbedingungen $\mathrm{RT}=$ Raumtemperatur, ü.N. = über Nacht 


\begin{tabular}{llll}
\hline & Hersteller & Konzentration & $\begin{array}{l}\text { Inkubations- } \\
\text { Bedingungen }\end{array}$ \\
\hline $\begin{array}{lll}\alpha \text {-Kaninchen, Ziege, } \\
\text { polyklonal }\end{array}$ & $\begin{array}{l}\text { Acris, Herford, } \\
\text { Deutschland }\end{array}$ & $\begin{array}{l}1: 30.000 \text { in 5 } \% \\
\text { Milch-PBST }\end{array}$ & 2h, RT \\
\hline $\begin{array}{l}\text { a-Maus, Kaninchen, } \\
\text { polyklonal }\end{array}$ & $\begin{array}{l}\text { Acris, Herford, } \\
\text { Deutschland }\end{array}$ & $\begin{array}{l}1: 30.000 \text { in 5 \% } \\
\text { Milch-PBST }\end{array}$ & 2h, RT \\
\hline
\end{tabular}

Tabelle 2.5: Sekundäre Antikörper mit verwendeter Konzentration und Inkubationsbedingungen RT = Raumtemperatur, ü.N. = über Nacht

\subsubsection{Verwendete Geräte}

Amaxa Nucleofactor ${ }^{(B)}$ II

BD FACSAria II cell sorter

Dissektionsmikroskop

Fluoreszenzmikroskop EC3

Fuji LAS3000 CCD Kamera

Gelelektrophoresekammer Xcell 4 Surelock MIDI Cell

iCycler

Magnetrührer

Minigel-Twin

MiniTrans Illuminator, UV imager

Nanodrop

$\mathrm{pH}$ Meter

Pipetus
Lonza, Köln, Deutschland

BD, Franklin Lakes, NJ, USA

Leica, Solms, Deutschland

Leica, Solms, Deutschland

Fujifilm, Düsseldorf, Deutschland

Invitrogen, Darmstadt, Deutschland

BioRad, München, Deutschland

Krannich, Göttingen, Deutschland

Biometra GmbH, Göttingen, Deutschland

BioRad, München, Deutschland

PEQLAB, Erlangen, Deutschland

Sartorius, Göttingen. Deutschland

Hirschmann, Eberstadt, Deutschland 
RNA6000 nano Lapchip

Schüttler

Semi Dry Blotting Apparatur

Sterile Werkbank Hera Safe

Thermomixer

Victor X4 Light Multilabel Reader

Vortexer lab dancer vario

Waage

Wasserbad

Zellkultur Inkubator

Zentrifuge 5415 D

Zentrifuge Heraeus Fresco 17
Agilent Technologies, Palo Alto, CA USA

Krannich, Göttingen, Deutschland

Biometra GmbH, Göttingen, Deutschland

Heraeus, Hanau, Deutschland

Eppendorf, Hamburg, Deutschland

PerkinElmer, Wiesbaden, Deutschland

Lennox, Dublin, Irland

Sartorius, Göttingen. Deutschland

GFL, Burgwedel, Deutschland

Labotect, Göttingen, Deutschland

Eppendorf, Hamburg, Deutschland

Thermo Scientific Open Biosystems, Huntsville, AL, USA

\subsubsection{Computer-Software}

BLAST Primer

Grapher 8

Image J

Microsoft Office 2007

Primer3 http://www.ncbi.nlm.nih.gov/tools/primerblast/index.cgi?LINK_LOC=BlastHome Apple Inc., Cupertino, CA, USA

NIH, Bethesda, MD, USA

Microsoft, Redmont, WA, USA

http://frodo.wi.mit.edu/cgi-

bin/primer3/primer3_www.cgi 


\subsubsection{Puffer und Lösungen}

\begin{tabular}{lll}
\hline & Trenngel & Sammelgel \\
\hline ddH $_{2} \mathrm{O}$ & $9,3 \mathrm{ml}$ & $3,4 \mathrm{ml}$ \\
Roti $^{\circledR}$ phorese & $5 \mathrm{ml}$ & $830 \mathrm{ml}$ \\
$4 \mathrm{x}$ Gelladepuffer & $5,3 \mathrm{ml}$ & $630 \mathrm{ml}$ \\
$10 \%$ SDS & $200 \mu \mathrm{l}$ & $50 \mu \mathrm{l}$ \\
TEMED & $20 \mu \mathrm{l}$ & $5 \mu \mathrm{l}$ \\
$10 \%$ APS & $200 \mu \mathrm{l}$ & $50 \mu \mathrm{l}$ \\
\hline
\end{tabular}

Tabelle 2.6: Zusammensetzung des achtprozentigen SDS-Gels

Blockierpuffer

Einfriermedium
$5 \mathrm{~g}$ Trockenmilch

100ml TBS- 0,1\% Tween20

Kulturmedium

$20 \%$ FBS

$10 \%$ DMSO

Fluorescence activated cell sorting (FACS) 500ml PBS pH=7,2

Puffer

2mM EDTA

$0,4 \%$ BSA

$137 \mathrm{mM} \mathrm{NaCl}$

$2,7 \mathrm{mM} \mathrm{KCl}$

$10,1 \mathrm{mM} \mathrm{Na}_{2} \mathrm{HPO}_{4}$

$1,76 \mathrm{mM} \mathrm{KH}_{2} \mathrm{PO}_{4}$ 
PBS-Tween

Transferpuffer (Western Blot)

Tris buffered saline (TBS) Puffer

TBS-Tween

Zelllysepuffer
PBS Puffer $+0,1 \%$ Tween 20

$48 \mathrm{mM}$ Tris

39mM Glycin

$0,037 \%$ SDS

$20 \%$ Methanol

$150 \mathrm{mM} \mathrm{NaCl}$

$50 \mathrm{mM}$ Tris $\mathrm{pH}=7,5$

TBS Puffer $+0,1 \%$ Tween 20

50mM Tris- $\mathrm{HCl} \mathrm{pH}=7,8$

$150 \mathrm{mM} \mathrm{NaCl}$

$1 \% \mathrm{NP}-40$ 


\subsection{Methoden}

\subsubsection{Zellkulturarbeiten}

Alle Zellkulturarbeiten wurden nach den Empfehlungen des Handbuches „Zell- und Gewebekultur“"von Toni Lindl angefertigt (Lindl 2002). Die Arbeit mit den Zellen fand an einer sterilen Werkbank unter der Verwendung von sterilen Materialien und Lösungen statt.

\subsubsection{Kultivierung}

Für die Experimente wurden die Zelllinien SW480, SW1116, Caco-2, LS513 und HT-29 verwendet, welche von der ATCC (American Type Culture Collection) bezogen wurden. Sie wurden aus primären Adenokarzinomen des Kolons etabliert und sind mikrosatellitenstabil. Damit repräsentieren sie die Mehrheit der kolorektalen Tumoren (Cunningham et al. 2010).

Alle genannten Zelllinien wachsen adhärent und wurden in Brutschränken mit einer wasserdampfgesättigten Atmosphäre bei $0 \% \mathrm{CO}_{2}$ (L-15 Medium) bzw. $5 \% \mathrm{CO}_{2}$ kultiviert. Alle zwei bis drei Tage wurde das Kulturmedium ausgetauscht. Beim Erreichen einer 80bis 90-prozentigen Konfluenz wurden die Zellen subkultiviert, was durch Waschen mit PBS und anschließender Behandlung mit 0,25\% Trypsin-EDTA geschah. Die Zellen wurden dabei fünf bis zehn Minuten bei $37{ }^{\circ} \mathrm{C}$ inkubiert, erneut mit Medium gewaschen und die abgelöste Zellsuspension in ein 15-ml-Röhrchen überführt. Das Röhrchen wurde fünf Minuten bei $800 \mathrm{rpm}$ zentrifugiert, das Pellet in frisches Medium aufgenommen und zum Teil wieder in die Kulturflasche überführt. Alle Experimente wurden bei einer 60- bis 70-prozentigen Konfluenz durchgeführt.

Durch die Rechtsmedizin des Universitätsklinikums Göttingen (Prof. Dr. Michael Klintschar) wurde ein short-tandem-repeat-Profiling der verwendeten Zelllinien durchgeführt. Diese Methode ermöglicht die Identitätsprüfung sowie den Ausschluss einer Kontamination durch andere Zelllinien (Masters et al. 2001). Um sicherzustellen, dass die 
kultivierten Zelllinien frei von Mykoplasmen sind, wurden sie alle drei Monate mit dem MycoAlert ${ }^{\circledR}$ Mycoplasma Detection Kit getestet.

\subsubsection{Zellzahlbestimmung}

Die Zellzahlbestimmung wurde mit der Neubauer-Zählkammer durchgeführt. Dazu wurde die Zellsuspension 1:10 mit Trypanblau-Lösung verdünnt und je $10 \mu \mathrm{L}$ pro Seite in die Zählkammer gegeben. Die Zellzahlbestimmung erfolgte in den zwei gegenüberliegenden äußeren Zählquadraten, welche wiederum jeweils 16 Quadrate enthalten. Die toten Zellen färben sich blau an, da der Farbstoff durch die defekte Zellmembran in diese Zellen eindringen kann. Tote Zellen werden bei einer Lebendzellzahl-Bestimmung vernachlässigt.

\subsubsection{Auftauen und Einfrieren von Zellen}

Zum Einfrieren wurde das Zellpellet mit einem Einfriermedium versetzt und je $2 \mathrm{ml}$ dieser Zellsuspension in ein Kryoröhrchen überführt. Die Zellen wurden für 24 Stunden in einem mit Isopropanol gefüllten Einfrierbehälter bei $-80^{\circ} \mathrm{C}$ in einem Tiefkühlfach gelagert und anschließend in flüssigen Stickstoff einer Temperatur von $-196^{\circ} \mathrm{C}$ überführt.

Zum Auftauen wurden die Zellen aus dem Stickstoff im Wasserbad auf $37^{\circ} \mathrm{C}$ erwärmt, in ein 15-ml-Reaktionsröhrchen mit dem entsprechenden Kulturmedium überführt und bei 800 rpm fünf Minuten zentrifugiert. Anschließend wurde das Zellpellet im vorgewärmten Kulturmedium resuspendiert und in Zellkulturflaschen überführt.

Diese Lagerung ist wichtig, um die Zellen vor Kontamination, Veränderungen im Genom über die Nutzungsdauer und vor anderen Einflüssen zu schützen. Ein weiterer wichtiger Aspekt für die Konservierung der Zellen ist das Anlegen einer Stockkultur, damit immer die gleichen Zellen für die Experimente verwendet werden können. 


\subsubsection{RNA-Isolation}

Die RNA wurde mithilfe des RNeasy Minikits nach Angaben des Herstellers isoliert und ihre Qualität mithilfe des RNA 6000 nano LabChip auf einem Agilent 2100 Bioanalyzer System entsprechend den Angaben des Herstellers bestimmt. Es wurde ausschließlich RNA mit einer hohen Qualität (RNA-Integritätsnummer, RIN 9-10) verwendet und anschließend bei $-80{ }^{\circ} \mathrm{C}$ gelagert.

\subsection{3. cDNA-Synthese}

Complementary DNA (cDNA) wird mittels des Enzyms Reverse Transkriptase aus mRNA synthetisiert. Hierzu wurde in dieser Arbeit SuperScript ${ }^{\circledR}$ II entsprechend den Angaben des Herstellers verwendet. Von jeder RNA-Probe wurden $5 \mu \mathrm{g}$ umgeschrieben und bei $-20{ }^{\circ} \mathrm{C}$ gelagert.

\subsubsection{Semi-quantitative real-time-PCR}

Die semi-quantitative real-time-PCR ermöglicht die Bestimmung der mRNA-Menge eines Gens (Rappolee et al. 1988).

Ein PCR-Zyklus besteht aus drei Schritten und wird etwa 30- bis 40-mal wiederholt:

Im Denaturierungsschritt wird die cDNA zunächst auf $94{ }^{\circ} \mathrm{C}$ erhitzt, sodass die DNADoppelstränge sich trennen.

In der Annealing-Phase wird die Temperatur wieder gesenkt, woraufhin die Primer sich an die DNA anlagern.

In der Elongations-Phase wird die Temperatur wieder erhöht, um die Synthese neuer DNADoppelstränge durch die DNA-Polymerase zu ermöglichen.

Am Ende eines PCR-Zyklus erfolgt die Quantifizierung des Produkts durch die Messung der Fluoreszenz eines DNA-interkalierenden Farbstoffs. 
Als Primer werden kurze DNA-Sequenzen bezeichnet, welche als Start- und Endpunkt der nachzuweisenden mRNA-Sequenz und als Ansatzstelle für die Polymerase dienen. Die in der vorliegenden Arbeit verwendeten Primer wurden mit der Software „Primer3“ entworfen und von der Firma MWG Biotech AG synthetisiert.

Die PCR wurde auf einem iCycler mit dem QuantiTectTM SYBR ${ }^{\circledR}$ Green RT-PCR Kit nach Angaben des Herstellers in Triplikaten mit einer optimierten Konzentration der genspezifischen Primer durchgeführt.

Folgendes Temperaturprogramm wurde verwendet:

1. Initiale Denaturierung bei $95^{\circ} \mathrm{C}$ zur Aktivierung der Taq-Polymerase.

2. 40 Zyklen von $95{ }^{\circ} \mathrm{C}$ für 15 Sekunden und $60{ }^{\circ} \mathrm{C}$ für eine Minute.

3. Schmelzkurvenanalyse mit einer Temperaturrampe von 60 bis $95{ }^{\circ} \mathrm{C}$ bei einer Heizrate von $3{ }^{\circ} \mathrm{C}$ pro Minute.

Mithilfe einer relativen Standardkurve eines cDNA-Mixes (eine zweifache Verdünnungsreihe mit sieben Messpunkten in Triplikaten) wurde die PCR-Effizienz bestimmt. Daraus ergab sich ein Regressionskoeffizient größer 0,98 und eine Effizienz größer $95 \%$. Durch einen Einzelpeak in der Schmelzkurvenanalyse konnte die genspezifische Amplifikation bestätigt werden. Für jedes Gen wurden Negativkontrollen (PCR ohne cDNA) und genomische Kontrollen (Durchführung der cDNA-Synthese ohne reverse Transkriptase) zur Bestimmung von genomischen Amplifikationen und PrimerDimerisierungen mitgeführt.

Die Normalisierung und die Berechnung der relativen Expression der zu bestimmenden Gene erfolgte mithilfe der drei Referenzgene F-box and leucine-rich repeat protein 12 (FBXL12), OTU domain, ubiquitin aldehyde binding 1 (OTUB1) und RAB35, member RAS oncogene family (RAB35) nach der Delta-Delta-Ct-Methode (Livak und Schmittgen 2001). Zur Quantifizierung ist die Messung der neu-synthetisierten DNA nötig. Dazu wird ein Fluoreszenzfarbstoff verwendet, welcher mit der erzeugten doppelsträngigen DNA interkaliert. Durch Laser-Anregung emittiert er Licht der Wellenlänge $520 \mathrm{~nm}$ und kann so während der Amplifikationsreaktion detektiert werden. Das Fluoreszenzsignal übertrifft ab einer bestimmten Zykluszahl das Hintergrundrauschen und steigt exponentiell an. Diese Zykluszahl bezeichnet man als Ct (Cycle Threshold)-Wert. 
Anschließend werden die Ct-Werte des Zielgens mit den Ct-Werten der Referenzgene (FBXL12, OTUB1 und RAB35) normalisiert, um die mRNA-Menge des Zielgens in Verhältnis zu einem Gen darzustellen, das unabhängig von äußeren Einflüssen immer in gleicher Menge abgelesen wird. Mithilfe der Ct-Werte und der Formel $2^{(\Delta \mathrm{Ct} \text { Probe } \mathrm{A})-(\Delta \mathrm{Ct} \text { Probe } \mathrm{B})}$ werden schließlich die Fold Changes $(=\mathrm{x}$-fache Änderungen $)$ errechnet, durch welche sich Aussagen $\mathrm{zu}$ der relativen mRNA-Expression in den verschiedenen Proben treffen lassen.

\subsubsection{Erstellen, Linearisieren und Aufreinigen der Vektoren}

In dieser Arbeit wurde das induzierbare Gateway ${ }^{\mathrm{TM}}$ Vektor System von Invitrogen verwendet. In Abbildung 2.1 sind die Elemente der beiden Vektoren pcDNA6/TR und pTREx-DEST31 schematisch dargestellt.

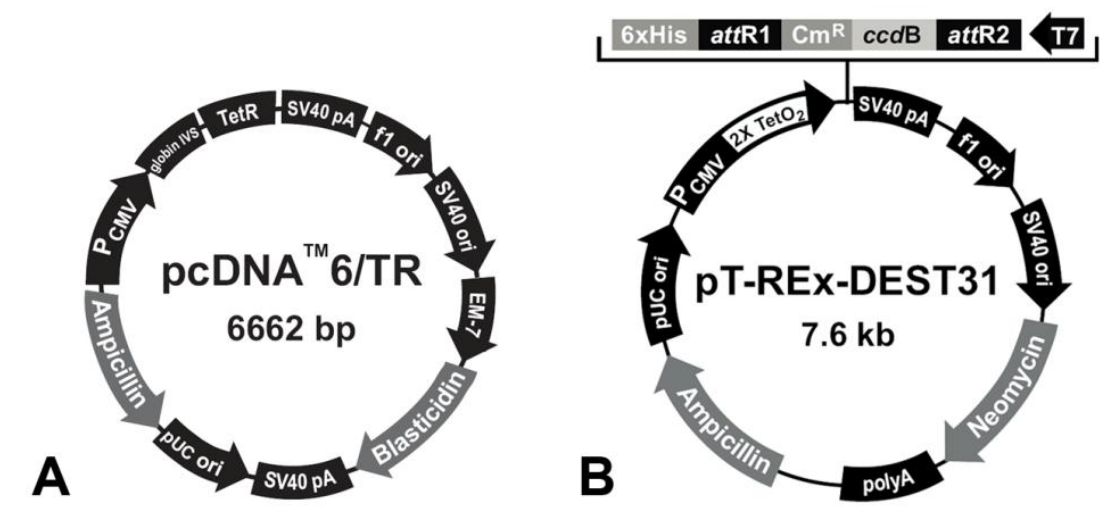

Abbildung 2.1: Struktur des (A) pcDNA6/TR- und (B) pT-REx-DEST31-Vektors (übernommen aus Invitrogen T-Rex ${ }^{\mathrm{TM}}$ System User Manual 2010 und Invitrogen pT-REx-DEST Gateway ${ }^{\mathrm{TM}}$ Vectors Instruction Manual 2010) 
Das Gateway ${ }^{\mathrm{TM}}$ Vektor-System basiert auf zwei Schritten:

1. Transfektion der Zellen mit dem pcDNA6/TR-Vektor. Dieser Vektor trägt die genetische Information für den Tet-Repressor. Nach Transfektion beginnt die Zelle den Tet-Repressor zu bilden. Die Blastizidinresistenz auf dem Vektor erlaubt eine Selektionierung der transfizierten Zelllinie, sodass eine stabile Zelllinie gezüchtet werden kann, die den Tet-Repressor exprimiert.

2. Transfektion der Zellen mit dem pT-REx-DEST31-Vektor. Dieser Vektor enthält die Sequenz desjenigen Gens, welches exprimiert werden soll. Davor befindet sich ein Zytomegalievirus (CMV)-Promotor mit einer Bindungsstelle für den Tet-Repressor. Bei der Gabe von Tetrazyklin dissoziiert der Tet-Repressor vom CMV-Promotor ab und bindet an Tetrazyklin. Dadurch wird der Promotor freigegeben und das Gen kann abgelesen werden (siehe Abbildung 2.2).

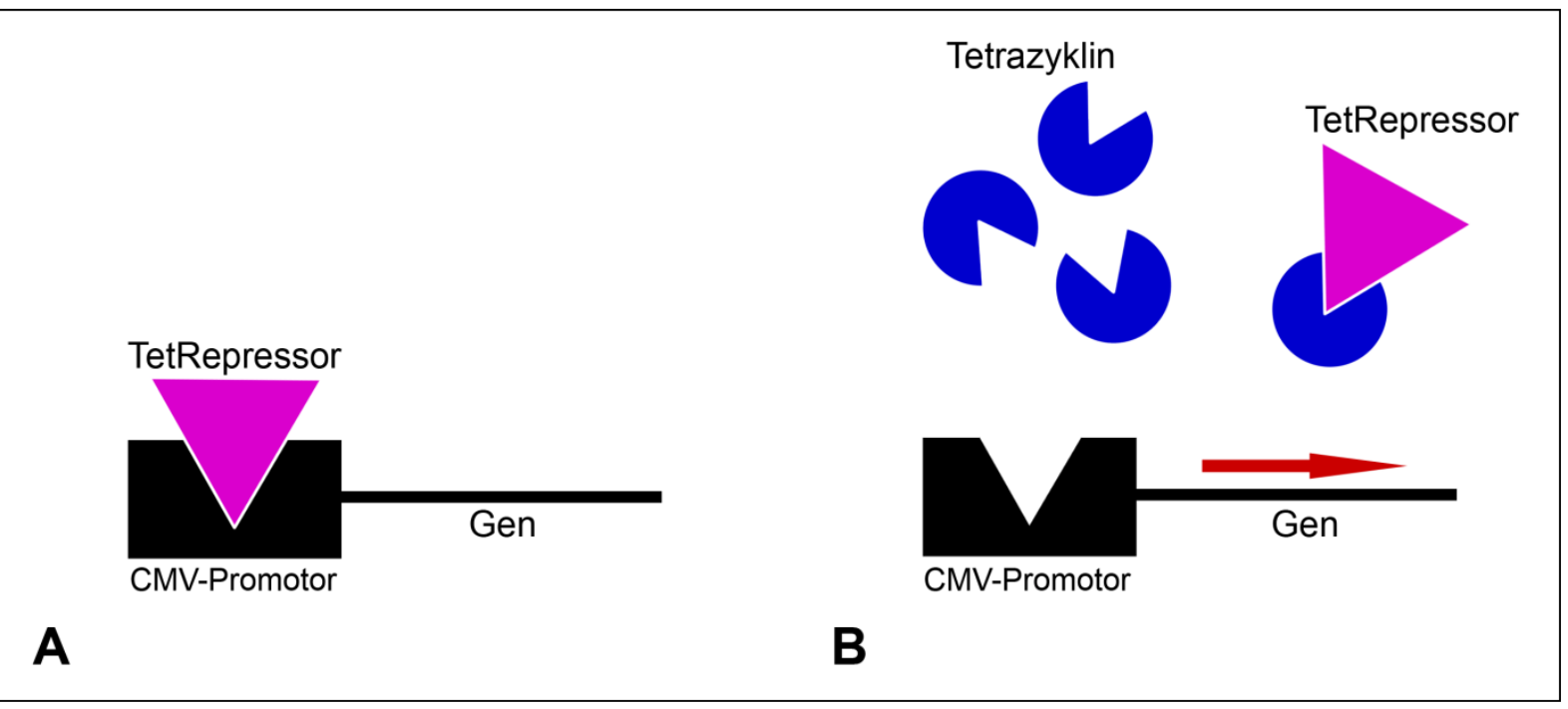

Abbildung 2.2: Schematische Darstellung der Funktionsweise des Tet-Repressors

(A) Der Tet-Repressor bindet an den Zytomegalievirus (CMV)-Promotor des Gens und verhindert so das Ablesen.

(B) Durch Zugabe von Tetrazyklin erfolgt eine Bindung des Tet-Repressors, sodass die Promotorstelle freigegeben wird und das Gen abgelesen werden kann. 
Im pT-REx-DEST31-Vektor ist eine sechsfache Sequenz für Histidin enthalten, die mit dem Gen abgelesen wird. So kann der Nachweis des exprimierten Gens mithilfe des Western Blots erleichtert werden. Außerdem trägt der Vektor eine Resistenzsequenz, welche eine Selektionierung der transfizierten Zelllinie mit dem Antibiotikum Genetizin erlaubt.

Die Vektoren, welche für die Gene pyruvate dehydrogenase kinase 4 (PDK4), nuclear receptor subfamily 3, group $C$, member 1 (NR3C1) und green fluorescent protein (GFP) kodieren, wurden von Dominic Esposito (Protein Expression Laboratory) an den National Institutes of Health (NIH) in Bethesda, Maryland, erstellt.

Durch Amplifikation von geprüften MGC Library Clones wurden Eingangsklone erzeugt und anschließend mittels Sequenzierung verifiziert. Danach erfolgte der Transfer in die pTREx-DEST31-Vektoren von Invitrogen mithilfe der Gateway-Technik zur Erzeugung von Expressionsklonen. Aus den Expressionsklonen wurde schließlich transfektionsfertige Plasmid-DNA gewonnen und mittels Gelelektrophorese verifiziert.

Pro Vektor wurden $10 \mu \mathrm{g}$ DNA linearisiert. Dafür wurden die eingefrorenen Vektoren aufgetaut und die entsprechenden Reagenzien (siehe Tabelle 2.7) hinzugefügt. Die Vektoren wurden für zwei Stunden bei $37^{\circ} \mathrm{C}$ und anschließend nochmal für 20 Minuten bei $65^{\circ} \mathrm{C}$ inkubiert.

Um die Restriktionsenzyme und Salze wieder aus dem Reaktionsansatz zu entfernen, wurden die Vektoren anschließend mit dem QIAEX II Gel Extraction Kit aufgereinigt. Der Erfolg der Linearisierung wurde mittels Gelelektrophorese überprüft.

\begin{tabular}{|l|l|}
\hline DNA & $10 \mu \mathrm{g}$ \\
Ahd1 & $4 \mu \mathrm{L}(20 \mathrm{U})$ \\
BSA 100x & $0,5 \mu \mathrm{L}$ \\
10x Puffer & $5 \mu \mathrm{L}$ \\
Aqua dest. & $40,5 \mu \mathrm{L}-\mathrm{V}$ (DNA) \\
\hline
\end{tabular}

Tabelle 2.7: Reagenzien zum Linearisieren der Vektoren 


\subsubsection{Transfektion}

Die Transfektion erfolgte mit dem Amaxa Nucleofector ${ }^{\circledR}$ Kit (Kit V). Diese Technologie basiert auf dem Prinzip der Elektroporation unter der Verwendung verschiedener Transfektionslösungen kombiniert mit elektrischen Parametern.

SW480 Zellen wurden bei 70-prozentiger Konfluenz aus der Kulturflasche gesplittet und gezählt. Jeweils eine Million Zellen wurden für die Transfektion mit 2,5 $\mu \mathrm{g}$ DNA verwendet. Die Zellen wurden in $100 \mu \mathrm{L}$ Nucleofector-Lösung aufgenommen, in die Amaxa Küvetten überführt und mit dem Programm T-030 transfiziert. Als Transfektionskontrolle diente ein GFP-Vektor von Amaxa, als Selektionskontrolle ein Well mit untransfizierten Zellen. Das Transfektionsschema ist in Abbildung 2.3 dargestellt.

Nach 24 Stunden wurde das Medium abgesaugt, die Zellen mit PBS gewaschen und neues Medium hinzugefügt. Am zweiten Tag nach der Transfektion erfolgte eine ca. zweiwöchige Selektion mittels Blastizidin für pcDNA6/TR oder Genetizin für den Vektor pT-RExDEST31, bis alle Zellen der Kontrolle tot waren.

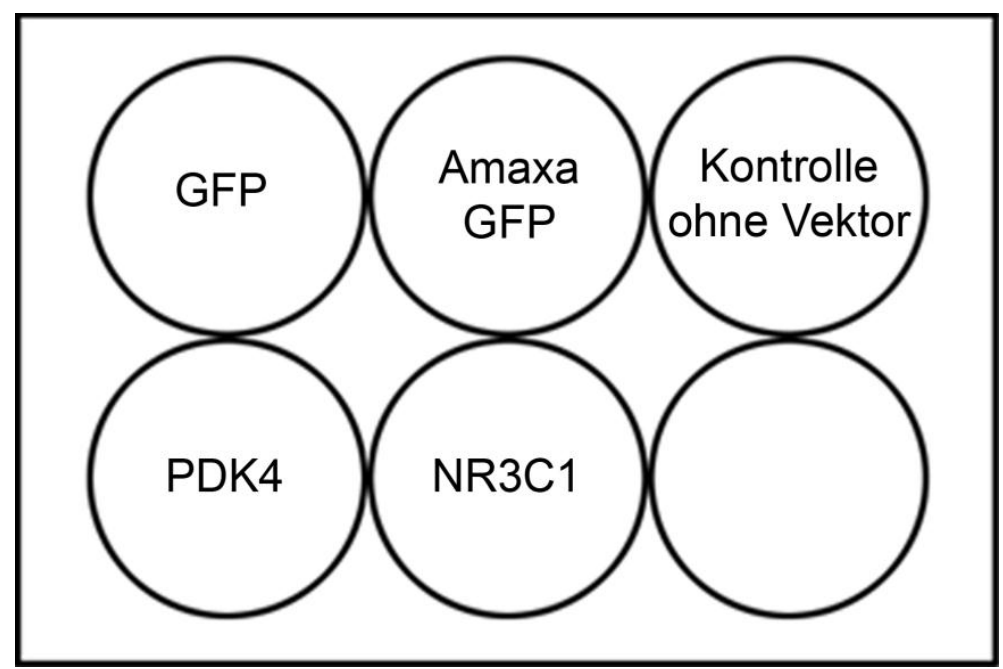

Abbildung 2.3: Belegung der Sechs-Well-Platte für die Transfektion mit dem Vektor pT-Rex-DEST31 


\subsubsection{Selektion}

Wie oben beschrieben enthalten die Vektoren pcDNA6/TR und pT-REx-DEST31 jeweils Antibiotikaresistenzen gegen Blastizidin bzw. Genetizin. Dies ermöglicht es, nach der Transfektion durch Zugabe des jeweiligen Antibiotikums die Zellen so zu selektionieren, dass nur diejenigen Zellen überleben, welche den Vektor in ihr Genom eingebaut haben und ihn exprimieren und somit resistent sind. Die restlichen Zellen sterben durch die Antibiotika-Wirkung ab. Blastizidin ist ein Nukleosid-Antibiotikum und hemmt die Proteinbiosynthese durch Inhibition der Peptidbindung. Das Aminoglykosid Genetizin bindet irreversibel an die 80S Ribosomenuntereinheit und blockiert die Proteinsynthese der Zellen (Invitrogen T-REx ${ }^{\mathrm{TM}}$ System User Manual 2010; Invitrogen pT-REx-DEST Gateway $^{\mathrm{TM}}$ Vectors Instruction Manual 2010).

Für die Selektion musste zunächst die optimale Konzentration jedes Antibiotikums in Konzentrationsreihen für die Zelllinie ermittelt werden. Hierzu wurden in jedes Well einer Sechs-Well-Platte 200.000 untransfizierte Zellen ausgesetzt. Jedes Well enthielt eine andere Konzentration des entsprechenden Antibiotikums (ansteigende Konzentrationsreihe). In einem Zeitraum von sieben Tagen erfolgte jeden zweiten Tag eine Zellzahlbestimmung für die einzelnen Wells. Die optimale Antibiotikakonzentration für die Selektion entspricht der kleinsten Konzentration, bei der die „parentalen“ Zellen ohne Plasmid (Wild-Typ) absterben.

\subsubsection{Einzelzellklonierung}

Um einen Klon zu erhalten, in dem der transfizierte Vektor in jeder Zelle an der gleichen Stelle im Genom enthalten ist und somit in gleichem Maße abgelesen wird, ist eine Einzelzellklonierung notwendig.

Hierzu wurde eine Zellsuspension mit insgesamt 32 Zellen pro $10 \mathrm{ml}$ Medium auf eine 96Well-Platte verteilt, sodass sich im Durchschnitt in jedem dritten Well eine Zelle befand. Nach 24 Stunden wurde unter dem Mikroskop geprüft, in welchem Well sich eine einzelne Zelle befand, und dieses markiert. Wie in Abbildung $2.4 \mathrm{zu}$ sehen ist, wurden die einzelnen 
Kolonien aus der 96-Well-Platte über eine 24-Well-Platte in eine Sechs-Well-Platte überführt und dann weiter bis zu einer T75-Flasche kultiviert. Daraus wurde ein Teil für die Proteinisolation ausgesetzt, ein Teil eingefroren und der Rest für weitere Experimente in der Kultur belassen.

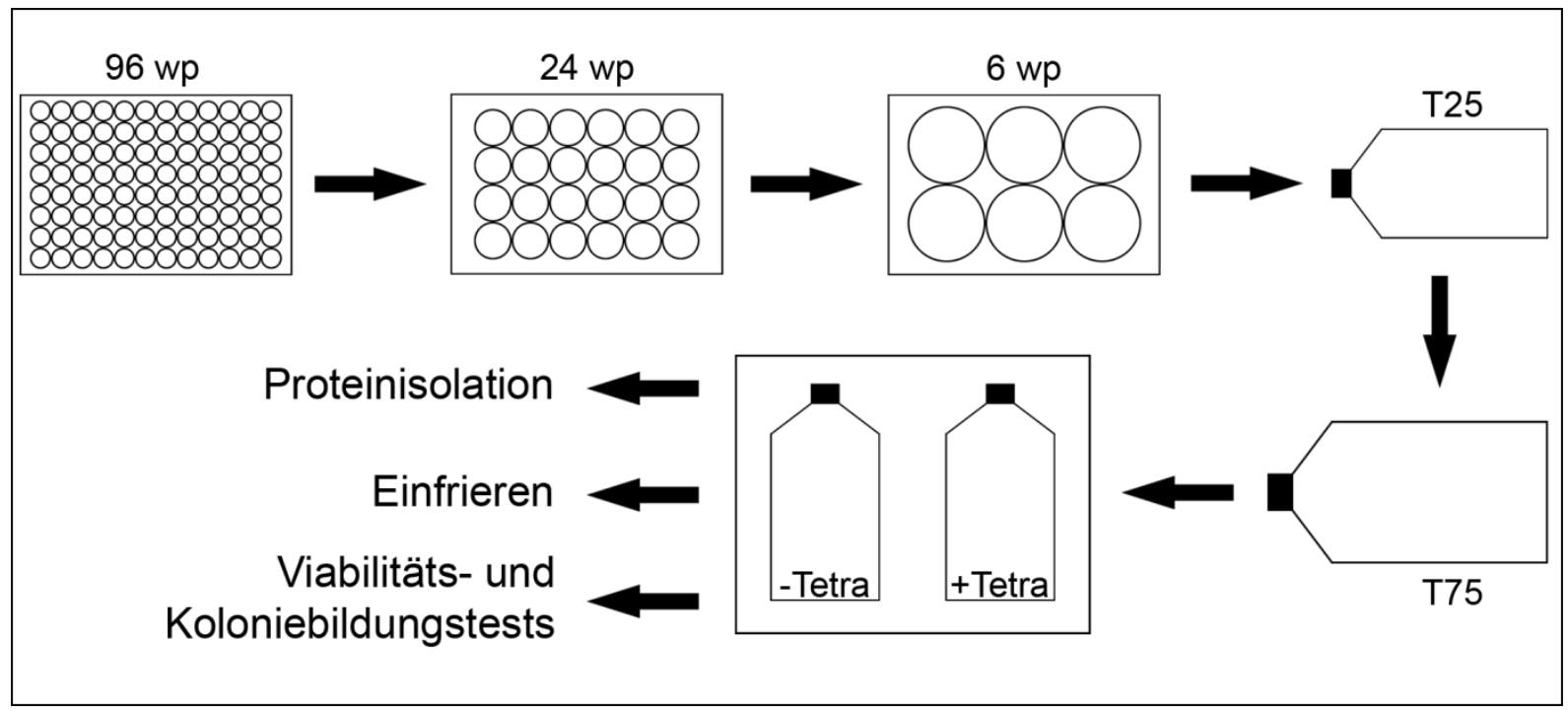

Abbildung 2.4: Schematische Darstellung des Vorgehens bei der Einzelzellklonierung

\subsubsection{Vektorinduktion}

Um eine größtmögliche Expression des Zielgens zu erreichen, wurden die Zellen für 72 Stunden alle 24 Stunden mit $1 \mu \mathrm{g} / \mathrm{ml}$ Medium Tetrazyklin induziert. Danach konnte das Protein für die Expressionsanalyse im Western Blot isoliert werden, bzw. die Zellen für Experimente verwendet werden.

Tetrazyklin hemmt die Proteinbiosynthese, indem es die Anlagerung der Aminoacyl-tRNA an die 30S Untereinheit der Ribosomen und somit die Verlängerung der Peptidkette verhindert. In den mit dem pcDNA6/TR-Vektor transfizierten Zellen bindet Tetrazyklin an den Tet-Repressor, der daraufhin den Promotor des Zielgens auf dem pT-REx-DEST31Vektor freigibt und somit die Ablesung ermöglicht. Tetrazyklin wirkt selektiv an bakteriellen Ribosomen und ist für humane Zellen in geringen Mengen nicht toxisch. Im 
Zellkulturmedium hat es bei $37{ }^{\circ} \mathrm{C}$ eine Halbwertszeit von etwa 24 Stunden (Invitrogen T$\mathrm{REx}^{\mathrm{TM}}$ System User Manual, 2010).

\subsubsection{FACS-Analyse}

Die fluoreszenzaktivierte Zellanalyse (FACS-Analyse oder Durchflusszytometrie) ist ein Verfahren zur Zählung und Charakterisierung von Partikeln in einem Flüssigkeitsstrom. Verschiedene Eigenschaften wie die Größe und die Fluoreszenzintensität können für mehrere tausend Zellen gleichzeitig ermittelt werden. Zur Analyse werden die Zellen einer Einzelzellsuspension einzeln nacheinander an einem gebündelten Laserstrahl vorbeigeleitet. Bei exakter Anregung der Elektronen des Fluoreszenzfarbstoffes durch den Laserstrahl werden diese auf ein höheres Energieniveau überführt. Nach dem Laserimpuls fallen die Elektronen unter Abgabe von Energie auf ihr Ursprungsniveau zurück. Die dabei emittierte Photonenkonzentration wird durch einen Photodetektor registriert (Herzenberg und Sweet 1976).

In dieser Arbeit wurden die mit dem GFP-Vektor transfizierten Zellen nach Proteininduktion mittels der FACS-Analyse auf ihre Induzierbarkeit überprüft. Zur Vorbereitung auf die FACS-Analyse mussten die Zellen zunächst in ihrer T75Kulturflasche mit $10 \mathrm{ml}$ PBS gewaschen und anschließend mit $1 \mathrm{ml}$ Trypsin für fünf Minuten bei $37^{\circ} \mathrm{C}$ inkubiert werden. Danach wurden die Zellen in Medium resuspendiert, in ein Zentrifugationsröhrchen überführt und für fünf Minuten bei $800 \mathrm{rpm}$ herunter zentrifugiert. Der Überstand wurde verworfen, die Zellen in $350 \mu 1$ FACS-Puffer aufgenommen und durch einen Einzelzellfilter in ein FACS-Röhrchen überführt. Die FACS-Analyse wurde anschließend im Diagnostiklabor der Universitätsmedizin Göttingen an einem BD FACSAria II cell sorter durchgeführt. 


\subsubsection{Proteinisolation}

Für die Proteinisolation wurden die Zellen mit jeweils $1 \mathrm{ml}$ PBS gewaschen und anschließend mit einem Cell Scraper vom Boden der Flasche abgelöst. Diese Zellsuspension wurde in Eppendorf-Cups überführt und zehn Minuten bei $1.500 \mathrm{rpm}$ zentrifugiert. Der Überstand wurde abgenommen und das Pellet entsprechend seiner Größe mit 50 bis $200 \mu \mathrm{L}$ Zelllysepuffer und Proteininhibitoren versetzt. Nach einer 45 -minütigen Inkubation auf Eis wurden die Zellsuspensionen zehn Minuten bei $10.000 \mathrm{rpm}$ zentrifugiert und der Überstand mit dem enthaltenden Protein in ein frisches Eppendorf-Cup überführt. Das isolierte Protein wurde bei $-80{ }^{\circ} \mathrm{C}$ bis zur weiteren Verwendung gelagert.

\subsubsection{Proteinbestimmung nach Bradford und Probenvorbereitung}

Die Konzentrationsbestimmung des isolierten Proteins erfolgte mit der Bradfordmethode. Durch die Bindung des Farbstoffes Coomassie-Brilliant-Blau an Proteine wird das Absorptionsmaximum verschoben. Ohne Protein liegt das Absorptionsmaximum des Farbstoffes bei $465 \mathrm{~nm}$, mit Protein bei $595 \mathrm{~nm}$. Die Zunahme der Absorption bei $595 \mathrm{~nm}$ ist somit ein Maß für die Proteinkonzentration in der Lösung (Bradford 1976).

Die Proben wurden 1:200 und 1:400 mit Aqua Bidest verdünnt und mit dem 5fach verdünnten Bradford-Reagenz Roti®Quant versetzt. Nach einer Inkubation von fünf Minuten wurde die Absorption bei $595 \mathrm{~nm}$ in einem Mikrotiterplattenlesegerät (Victor X4 Light Multilabel Reader) gemessen. Die Konzentrationen wurden anschließend anhand einer BSA-Kalibrierungsgeraden im Bereich von 0 bis $100 \mu \mathrm{g} / \mathrm{ml}$ berechnet.

Für die Vorbereitung zur Verwendung in der SDS-Polyacrylamid-Gelelektrophorese (SDSPAGE) wurde zu den Proben ein 4fach-SDS-Ladepuffer gegeben, welcher SDS zur negativen Ladung der Proteine, Bromphenolblau zur Markierung der Lauffront und betaMercaptoethanol zur Aufspaltung der Schwefelbrücken zwischen den Cystinen enthält. Nach Zugabe des Ladepuffers zur Probe erfolgte die Probendenaturierung für fünf Minuten bei $95{ }^{\circ} \mathrm{C}$. Anschließend wurde entweder direkt eine SDS-PAGE durchgeführt oder die Proben wurden bis zur weiteren Verwendung bei $-20{ }^{\circ} \mathrm{C}$ kurzfristig eingefroren. 


\subsubsection{SDS-Polyacrylamid-Gelelektrophorese}

Die Methode der SDS-PAGE wurde 1970 von Laemmli etabliert. Die Elektrophorese ermöglicht es, ein Proteingemisch unter Anlegen eines elektrischen Feldes in einem Gel aufzutrennen und mithilfe eines Proteinstandards (Marker) das Molekulargewicht dieser Proteine zu bestimmen. Die Auftrennung der Proteine erfolgt nach ihrer Größe, da die Ladung durch Zugabe von SDS bei allen Proteinen gleich ist. SDS verleiht den Proteinen eine negative Ladung, sodass sie zur Anode (positiver Pol) laufen (Laemmli 1970).

Zur Durchführung der Elektrophorese wurde entweder ein fertig gegossenes Gradientengel (4-12\%) von Invitrogen verwendet oder ein achtprozentiges Gel selbst gegossen. In jede Geltasche wurden $20 \mu \mathrm{g}$ Protein pipettiert. Als Proteinstandards wurden auf jedes Gel der Magic MarkTM ( $1 \mu 1$, sichtbar bei der Immunodetektion durch den zweiten Antikörper) und der Spectra Broad Range Protein Ladder (5 $\mu$, sichtbar auf dem SDS Gel und der PVDF Membran) aufgetragen.

Das beladene Gel wurde in einer Gelelektrophoresekammer befestigt, die Kammer mit SDS-Laufpuffer gefüllt und das Gel bei einer Spannung von $200 \mathrm{~V}$ für 45 bis 90 Minuten laufen gelassen.

\subsubsection{Western Blot}

Als Western Blot bezeichnet man den Transfer von elektrophoretisch aufgetrennten Proteinen aus einem Polyacrylamidgel auf eine Membran. Diese Methode wurde 1979 von Renart beschrieben und ermöglicht den immunologischen Nachweis der immobilisierten Proteine durch spezifische Antikörper (Renart et al. 1979).

Die Proteine in dem SDS-PAGE Gel wurden zwischen Filterpapieren in einer Blotapparatur unter Anlegen eines konstanten Stroms (ca. 1-2 mA/cm² Gelfläche, ein bis zwei Stunden) auf eine Polyvinylidenfluorid (PVDF)-Membran übertragen. Die Filterpapiere wurden dabei mit Transferpuffer befeuchtet, damit das Gel nicht austrocknet (Semi-Dry-Verfahren). Die PVDF-Membran wurde vorher zur Aktivierung in Methanol, destilliertes Wasser und Transferpuffer eingelegt. Die Übertragung und Immobilisierung 
der Proteine erfolgte elektrophoretisch. Anschließend wurde eine Immundetektion mithilfe von Antikörpern durchgeführt.

\subsubsection{Immunodetektion}

Die Membran wurde zur Absättigung der unspezifischen Bindungen nach dem Blotten eine Stunde in Blockierpuffer gelegt und anschließend mit dem ersten Antikörper auf einem Schüttler inkubiert. Die antikörperspezifischen Bedingungen sind im Materialteil (Kapitel 2.1.7) nachzulesen. Danach wurde der nicht gebundene Antikörper durch mehrmaliges Waschen für insgesamt 15 Minuten in TBST entfernt. Die Inkubation mit dem sekundären Antikörper erfolgte für zwei Stunden in fünfprozentiger Trockenmilch, gelöst in TBST, bei Raumtemperatur auf einem Schüttler. Der nicht gebundene Antikörper wurde durch mehrmaliges Waschen (insgesamt 15 Minuten) entfernt. Die Entwicklung der Membran erfolgte durch Inkubation in Western-Lightening Lösung (ECL) mit anschließender Belichtung mithilfe des Fuji-Film LAS 3000 CCD Imaging System.

Die Intensität der Proteinbanden auf dem Western Blot konnte mit der ImageJ Software ausgewertet werden, welche vom National Institute of Health in Bethesda, Maryland, USA entwickelt wurde.

\subsubsection{Viabilitätstest}

Zur Viabilitätsmessung der Klone wurde der CellTiter-Blue ${ }^{\circledR}$ Cell Viability Assay verwendet. Dieser Assay misst die metabolische Aktivität der Zellen, die eine irreversible Reduktion von Resazurin zu Redorufin in gesunden Zellen ermöglicht. Dadurch entsteht ein messbares Fluoreszenzsignal, das direkt proportional zu der Anzahl der lebenden Zellen ist (Promega CellTiter-Blue ${ }^{\circledR}$ Cell Viability Assay Technical Bulletin 2009).

Die Zellen wurden mit einer definierten Zellzahl von 3.000 Zellen pro Well auf zwei 96Well-Platten ausgesetzt. Es wurden jeweils mit Tetrazyklin induzierte und uninduzierte Zellen verglichen (siehe Abbildung 2.5). 


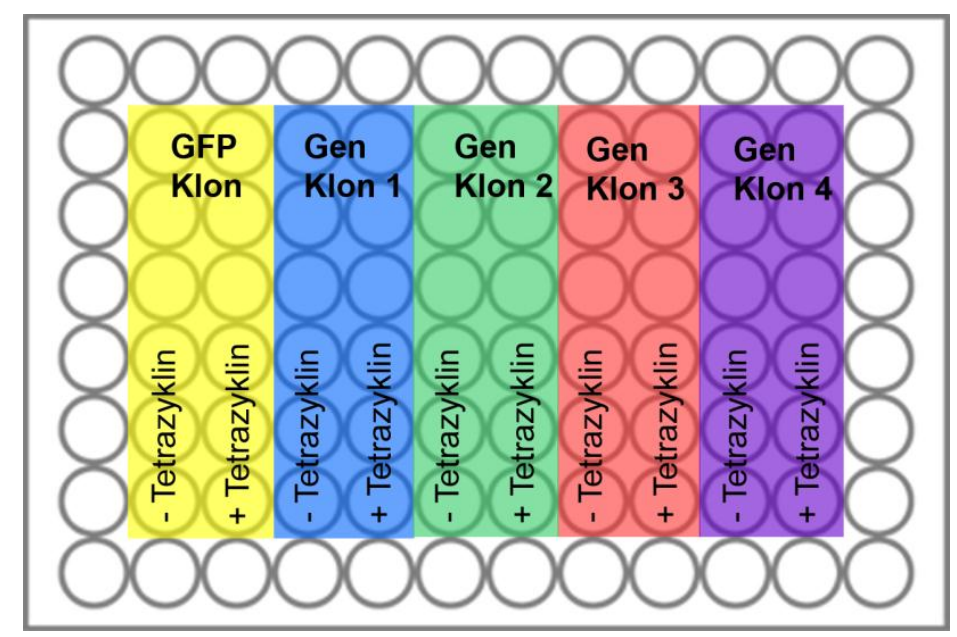

Abbildung 2.5: Belegung der 96-Well-Platte für den Viabilitätstest

Alle 24 Stunden wurden in die entsprechenden Wells $1 \mu \mathrm{g} / \mathrm{ml}$ Tetrazyklin zugegeben. Als Negativkontrolle wurde GFP mitgeführt. Die äußeren Wells wurden nur mit Medium gefüllt und dienten als Referenz für die Ermittlung der Eigenfluoreszenz des Farbstoffes. Zu der ersten Platte wurden nach 72 Stunden und zu der zweiten Platte nach 96 Stunden je $34 \mu \mathrm{l}$ CellTiter-Blue ${ }^{\circledR}$ Cell Viability Assay Reagenz pro Well hinzu pipettiert. Nach jeweils einer Stunde Inkubation wurde die Extinktion bei $595 \mathrm{~nm}$ im Victor X4 Light Multilabel Reader gemessen. Der Durchschnittswert der Referenz-Wells wurde den gemessenen Werten jeweils abgezogen und der Mittelwert der induzierten Zellen mit den uninduzierten Zellen verglichen.

\subsubsection{Koloniebildungstest}

Um zu überprüfen, ob die überexprimierten Gene die Fähigkeit der Zellen zur Koloniebildung verändern, wurde ein Koloniebildungstest durchgeführt. Dieser Test überprüft das Vermögen jeder einzelnen Zelle, sich in der gesetzten Population unbegrenzt zu teilen (Franken et al. 2006). 
Hierzu wurden die Zellklone jeweils sechsmal mit je 200 Zellen pro Well auf einer SechsWell-Platte ausgesetzt. Als Negativkontrolle wurde GFP mitgeführt (siehe Abbildung 2.6). Drei der Wells wurden täglich mit $1 \mu \mathrm{g} / \mathrm{ml}$ Tetrazyklin induziert. Am vierten Tag wurde ein Mediumwechsel durchgeführt. Nach neun Tagen wurden die Zellen mit $1 \mathrm{ml}$ Ethanol abgestoppt und getrocknet. Die Färbung erfolgte für fünf Minuten mit Kristallviolett. Anschließend wurden die Platten erneut getrocknet und nur die Kolonien mit mehr als 50 Zellen pro Kolonie unter dem Mikroskop ausgezählt. Für die Gene NR3C1, PDK4 und GFP wurde der Mittelwert der gebildeten Kolonien uninduzierter und induzierter Klone jeweils errechnet. Die Koloniezahlen der induzierten Klone wurden zu denen der uninduzierten Klone in ein Verhältnis gesetzt.

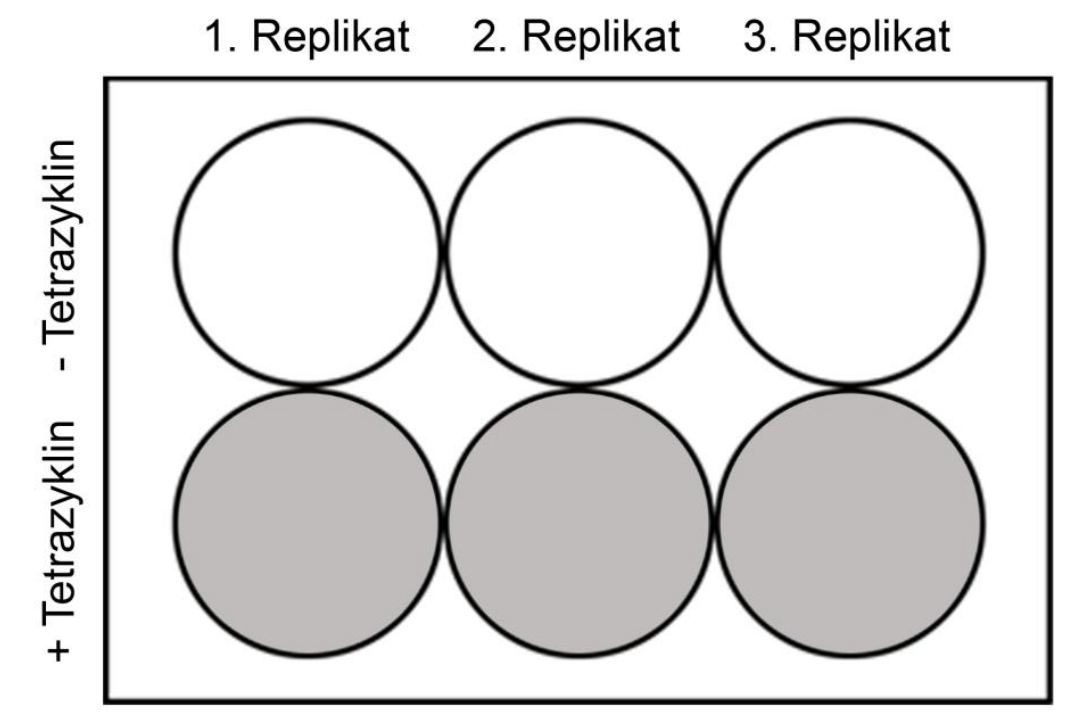

Abbildung 2.6: Belegung der Sechs-Well-Platte für den Koloniebildungstest 


\section{Ergebnisse}

\subsection{Genexpressionsanalysen kolorektaler Tumoren}

2007 untersuchte unsere Arbeitsgruppe 73 primäre Kolonkarzinome in einem Oligonukleotid-Mikroarray auf ihre Genexpression. 30 dieser Tumorproben wurden mit Proben von normaler Mukosa des jeweiligen Patienten verglichen. Die Proben stammten von Patienten, die in der Abteilung für Allgemein- und Viszeralchirurgie in Göttingen behandelt wurden. Es wurden 1.950 Gene identifiziert, die zwischen Tumor und Mukosa hochsignifikant dereguliert waren $(\mathrm{P}<1 \mathrm{e}-7)$. Davon waren 1.582 Gene im Tumor hochreguliert, 368 Gene zeigten eine verminderte Expression in der Tumorprobe im Vergleich zur Mukosa (Grade et al. 2007).

\subsection{PCR-Validierung in Zelllinien}

Um auf diese Ergebnisse aufbauende, funktionelle Experimente in vitro durchzuführen, eignen sich besonders gut etablierte kolorektale Karzinomzelllinien, da diese in vielen Forschungsgebieten zur Anwendung kommen, um biologische Sachverhalte an einem Modellsystem zu untersuchen.

In einem ersten Schritt wurden die Expressionsdaten aus dem Array in den Zelllinien SW480, SW1116, Caco-2, LS513 und HT-29 mittels semi-quantitativer real-time-PCR überprüft und dabei mit der Expression dieser Gene in einem Pool gesunder Mukosa verglichen.

Untersucht wurden folgende Gene:

- carbonic anhydrase $V(C A 5 A)$

- $\quad$ pyruvate dehydrogenase kinase, isozyme 4 (PDK4)

- nuclear receptor subfamily 3 (NR3C1), kodiert für den Glukokortikoid-Rezeptor (GR) 
- $\quad$ nudix (nucleoside diphosphate linked moiety X)-type motif 11 (NUDT11)

- membrane-spanning 4-domains, subfamily A, member 12 (MS4A12)

- chloride channel accessory 4 (CLCA4).

Aus den errechneten Fold Changes (siehe Tabelle 3.1) ergab sich in der semi-quantitativen real-time-PCR bei fünf von sechs Genen in allen fünf Zelllinien eine stark verminderte Genexpression. PDK4, NR3C1, NUDT11, MS4A12 und CLCA4 zeigten in den Zelllinien SW480, SW1116, Caco-2, LS513 und HT-29 kontinuierlich einen Fold Change kleiner 0,6. Besonders in der Zelllinie SW480 war eine geringe Expression der getesteten Gene zu finden. CLCA4 wies bei der semi-quantitativen real-time-PCR mit einem Fold Change von $4,882 * 10^{-4}$ die stärkste Herunterregulation in SW480 auf. Nur das Gen CA5A war in allen Zelllinien außer SW480 hochreguliert. Die stärkste Expression war mittels der semiquantitativen real-time-PCR in der Zelllinie LS513 bei einem Fold Change von 105,420 festzustellen.

\begin{tabular}{|c|c|c|c|c|c|c|}
\hline \multirow{2}{*}{ Gene } & $\begin{array}{c}\text { Fold Change } \\
\text { im Array }\end{array}$ & \multicolumn{5}{|c|}{ Fold Change in der semi-quantitativen real-time-PCR } \\
\cline { 2 - 7 } & Tumor & SW480 & SW1116 & Caco-2 & LS513 & HT-29 \\
\hline CA5A & $\mathbf{0 , 5 0 9}$ & $\mathbf{0 , 5 1 8}$ & 2,701 & 7,908 & 105,420 & 23,643 \\
\hline PDK4 & $\mathbf{0 , 4 6 1}$ & $\mathbf{0 , 0 0 1}$ & $\mathbf{0 , 0 1 5}$ & $\mathbf{0 , 0 0 1}$ & $\mathbf{0 , 0 0 6}$ & $\mathbf{0 , 0 2 3}$ \\
\hline NR3C1 & $\mathbf{0 , 3 6 7}$ & $\mathbf{0 , 0 1 6}$ & $\mathbf{0 , 1 3 5}$ & $\mathbf{0 , 3 4 5}$ & $\mathbf{0 , 0 3 8}$ & $\mathbf{0 , 0 2 0}$ \\
\hline NUDT11 & $\mathbf{0 , 3 5 0}$ & $\mathbf{0 , 1 8 2}$ & $\mathbf{0 , 0 3 4}$ & $\mathbf{0 , 0 1 8}$ & $\mathbf{0 , 1 4 9}$ & $\mathbf{0 , 2 7 6}$ \\
\hline MS4A12 & $\mathbf{0 , 1 5 3}$ & $\mathbf{0 , 0 0 2}$ & $\mathbf{0 , 1 3 3}$ & $\mathbf{0 , 0 9 3}$ & $\mathbf{0 , 5 4 7}$ & $\mathbf{0 , 5 8 4}$ \\
\hline CLCA4 & $\mathbf{0 , 1 4 5}$ & $\mathbf{4 , 8 8 2 * 1 0 ^ { - 4 }}$ & $\mathbf{0 , 0 0 7}$ & $\mathbf{0 , 0 0 4}$ & $\mathbf{0 , 0 4 0}$ & $\mathbf{0 , 0 4 4}$ \\
\hline
\end{tabular}

Tabelle 3.1: Fold Changes der Genexpression im Mikroarray und der Validierungs-PCR

Der Fold Change errechnet sich aus dem Wert der Expression gemessen im Tumor bzw. in der Zelllinie dividiert durch den Wert der Expression gemessen in der gesunden Mukosa. Vermehrte Expression im Tumor ist in Rot, verminderte Expression im Tumor in Blau dargestellt. 
SW480 zeigte im Vergleich mit den anderen Zelllinien eine besonders niedrige Expression für alle validierten Gene. Aus diesem Grund und weil SW480 durch seine typischen chromosomalen Aberrationen ein sehr gutes Modell für das kolorektale Karzinom darstellt, wurde SW480 als Zelllinie für die funktionellen Analysen bestimmt.

Die in SW480 sehr stark herunterregulierten Gene PDK4 und NR3Cl erwiesen sich nach intensiver Literaturrecherche als besonders interessant und wurden somit für die weiteren funktionellen Analysen ausgewählt.

\subsection{Herstellung von stabilen Zellklonen}

Für die funktionellen Experimente sollten stabile Zelllinien hergestellt werden, die das Vektorsystem pcDNA6/TR zur stabilen Herstellung des Proteins Tet-Repressor (SW480pcDNA6/TR) und das mit Tetrazyklin induzierbare Überexpressionssystem pT-REx-DEST31 für die stabile Proteinexpression von PDK4 bzw. GR enthalten.

\subsubsection{Bestimmung der Antibiotikakonzentrationen für die Selektion}

Zur Ermittlung der für die Selektion zu verwendenden Antibiotikakonzentrationen wurden Konzentrationsreihen mit Blastizidin für SW480 und Genetizin für SW480pcDNA6/TR erstellt. Die Zellen wurden an drei Zeitpunkten (2., 4. und 7. Tag) ausgezählt. Auf dem Vektor pcDNA6/TR befindet sich eine Resistenz für Blastizidin, auf dem Vektor pT-Rex-DEST31 für Genetizin. Die optimale Antibiotikakonzentration für die Selektion entspricht daher der kleinsten Konzentration, bei der die parentalen Zellen ohne Plasmid absterben.

Für Blastizidin wurden bei einer Ausgangszellzahl von 100.000 Zellen pro Well sechs verschiedene Konzentrationen von 0 bis $9 \mu \mathrm{g} / \mathrm{ml}$ gewählt. Die Zellzahl in den Wells ohne Antibiotikum stieg während des Beobachtungszeitraums exponentiell an. Ab einer Konzentration von $3 \mu \mathrm{g} / \mathrm{ml}$ war ein Abfall der Zellzahl in den drei Zähltagen zu 
beobachten. Ab einer Konzentration von $5 \mu \mathrm{g} / \mathrm{ml}$ waren am siebten Tag keine Zellen mehr im Well vorhanden (siehe Abbildung 3.1). Aufgrund dieser Ergebnisse wurde eine Blastizidinkonzentration von $5 \mu \mathrm{g} / \mathrm{ml}$ für die Selektion von SW480pcDNA6/TR gewählt und dem Medium nach der Transfektion mit dem Tet-Repressor beigefügt.

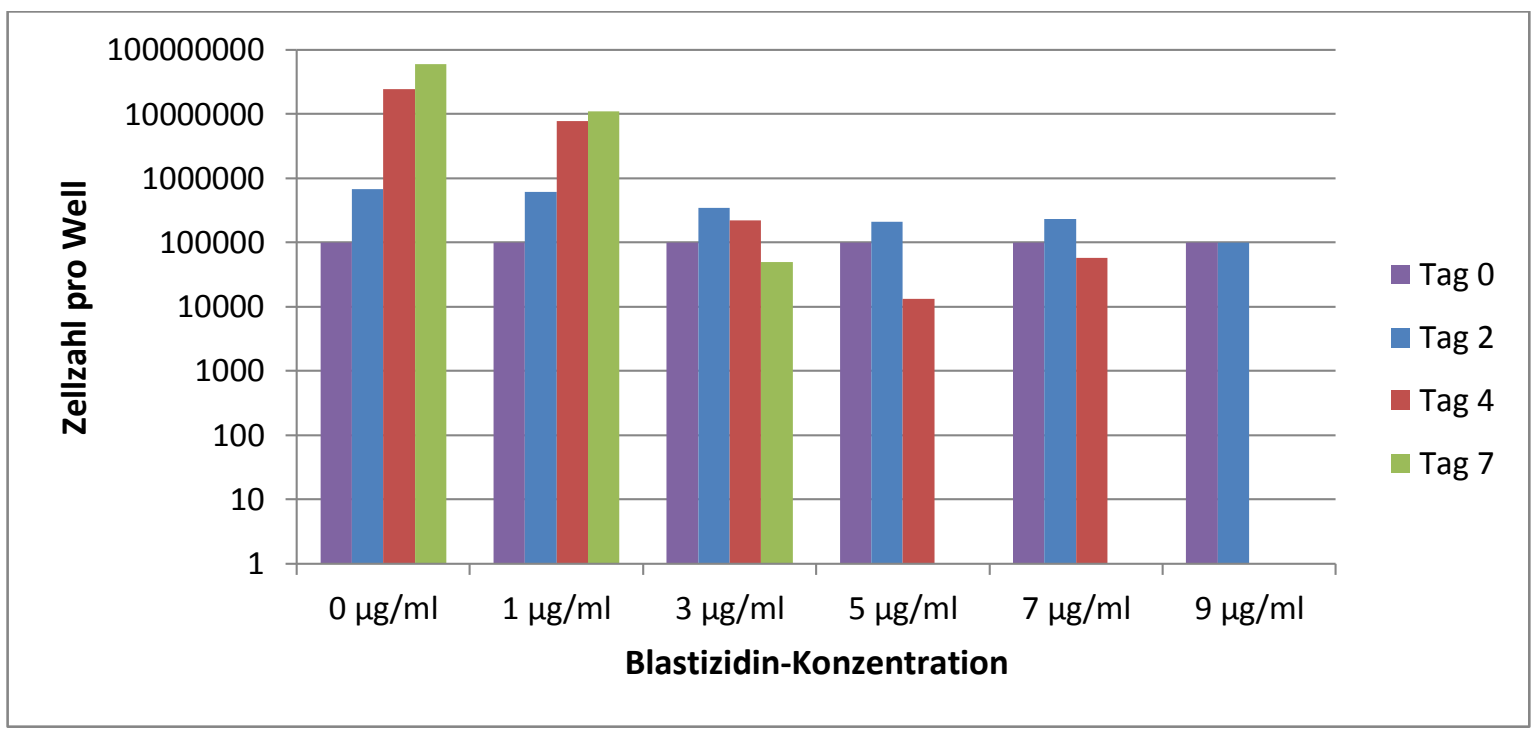

Abbildung 3.1: Ermittlung der optimalen Antibiotikakonzentration für die Selektion von SW480 mit Blastizidin über sieben Tage

Die SW480pcDNA6/TR-Zellen (Herstellung siehe Abschnitt 3.3.2) wurden bei einer Anfangszellzahl von 200.000 Zellen pro Well über sieben Tage mit GenetizinKonzentrationen von 0 bis $500 \mu \mathrm{g} / \mathrm{ml}$ inkubiert. Bei einer Konzentration von $0 \mu \mathrm{g} / \mathrm{ml}$ war an den drei Zähltagen ein Anstieg der Zellzahl zu beobachten. Ab einer Konzentration von $200 \mu \mathrm{g} / \mathrm{ml}$ war die gezählte Zellzahl am siebten Tag bereits niedriger als die Ausgangszellzahl und ab einer Konzentration von $300 \mu \mathrm{g} / \mathrm{ml}$ konnten am siebten Tag keine Zellen mehr im Well gesehen werden (siehe Abbildung 3.2). Für die Selektion von SW480pcDNA6/TR-Zellen wurde aufgrund dessen eine Antibiotikakonzentration von $300 \mu \mathrm{g} / \mathrm{ml}$ gewählt. 


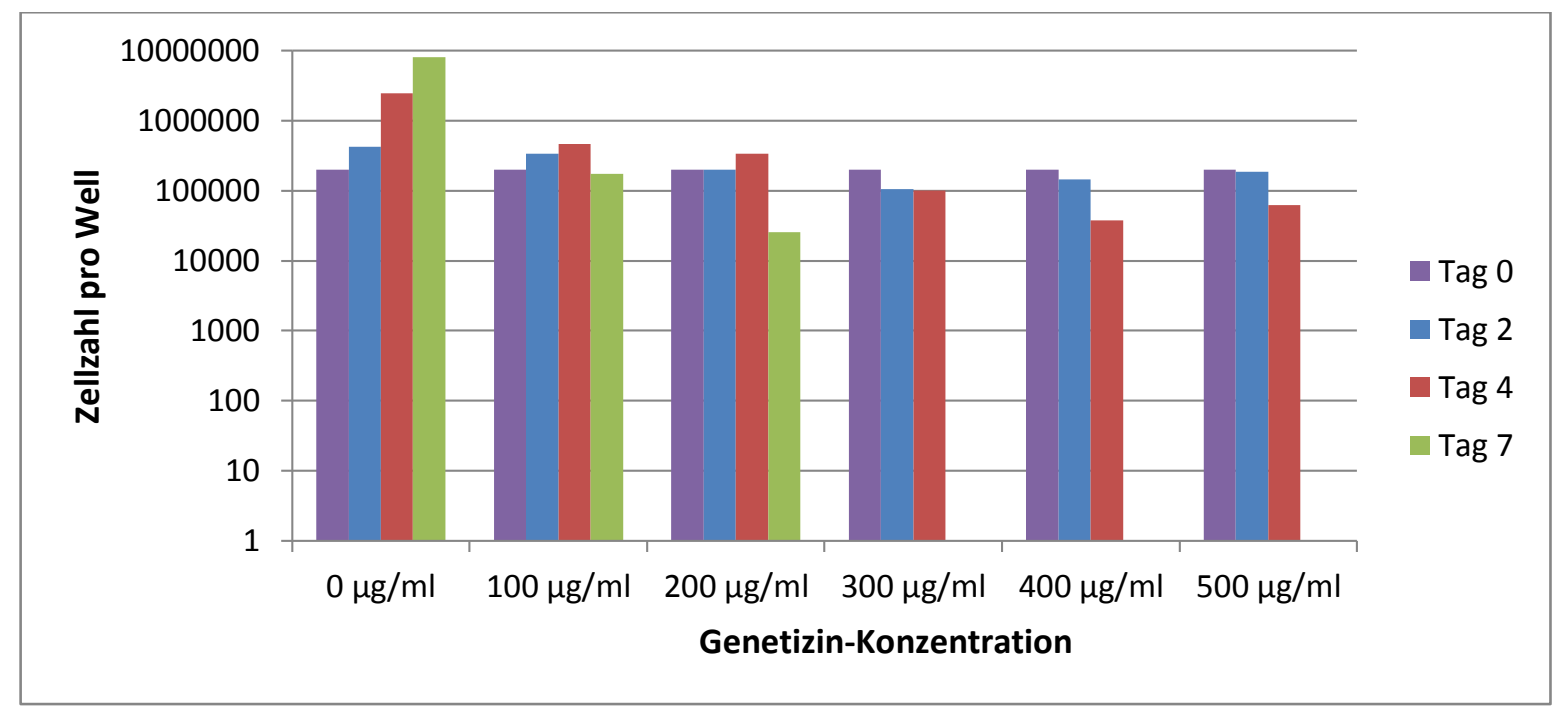

Abbildung 3.2: Ermittlung der optimalen Antibiotikakonzentration für die Selektion von SW480pcDNA6/TR mit Genetizin über sieben Tage

\subsubsection{Stabile Tet-Repressor-Expression in SW480}

Nach Bestimmung der kleinsten wirksamen Antibiotikadosis für die spätere Selektion wurde mit der Transfektion des Vektors pcDNA6/TR in die parentale Zelllinie SW480 begonnen. Die Einzelzellklonierung erfolgte direkt nach der Selektion aus der stabilen heterogenen Zelllinie SW480pcDNA6/TR.

Die Expression des Proteins Tet-Repressor in den SW480-Einzelzellklonen wurde im Western Blot durch einen Tet-Repressor-Antikörper nachgewiesen. Als Positivkontrolle für die Tet-Repressor-Expression diente das Proteinlysat von in Vorexperimenten hergestellten SW480 Zellen, welche ebenfalls Tet-Repressor exprimieren (im Weiteren als Positivkontrolle bezeichnet). Für den Nachweis einer gleichmäßigen Proteinladung wurde Aktin verwendet. Die Tet-Repressor-Expression sowie die Aktin-Expression aller Klone konnte durch Quantifizierung der Banden des Western Blots mit dem Computerprogramm ImageJ ermittelt werden (siehe Abbildung 3.3). 
Die relative Proteinexpression der einzelnen Klone errechnete sich wie folgt:

$$
\text { relative Proteinexpression }=\frac{\text { Proteinexpression }}{\text { Aktin }- \text { Expression }}
$$

\section{A}

Tet-Repressor

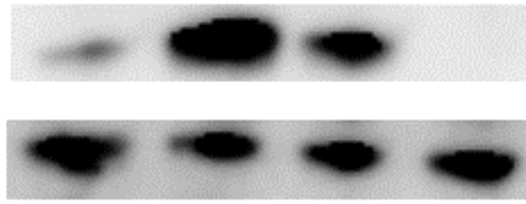

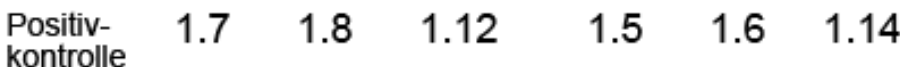

B

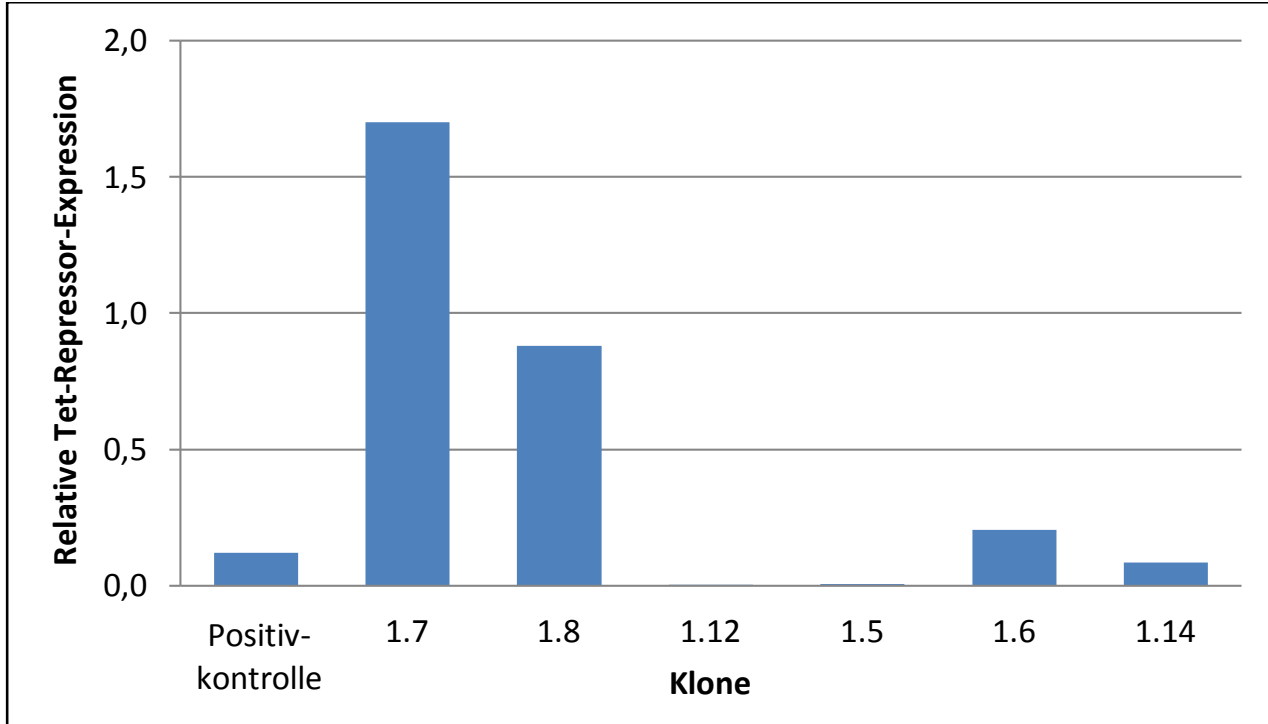

Abbildung 3.3: Die Tet-Repressor-Expression in den Einzelzellklonen

A Western Blot mit Tet-Repressor-Banden bei $25 \mathrm{kDa}$ und Aktinbanden bei $42 \mathrm{kDa}$

B Grafische Darstellung der relativen Tet-Repressor-Expression der Einzelzellklone im Vergleich

In Abbildung 3.3 sind sechs Einzelzellklone gezeigt. Die Klone 1.7, 1.8., 1.6 und 1.14 wiesen eine Expression des Tet-Repressors auf, wohingegen in den Klonen 1.12 und 1.5 
mit dem Western Blot kein Tet-Repressor detektierbar war. Die Positivkontrolle zeigte hierbei eine relativ leichte Expression im Vergleich zu den neu etablierten Klonen. Der Klon 1.7 wies in mehreren Wiederholungen die stärkste Expression des Tet-Repressors auf und wurde somit als Basiszelllinie für die Transfektion mit NR3C1, PDK4 und GFP verwendet.

\subsubsection{Herstellung von GFP-exprimierenden Zellen}

Als Kontrolle für die funktionellen Analysen von GR- und PDK4-überexprimierenden Klonen wurden zusätzlich GFP-exprimierende Klone erstellt. GFP ist ein Protein, das bei Anregung mit blauem oder ultraviolettem Licht grün fluoresziert. Es wirkt sich nicht auf Zellfunktionen und die Expression anderer Proteine in der Zelle aus. GFP hat eine Größe von $26,9 \mathrm{kDa}$.

Die Herstellung der Kontrollzelllinie erfolgte über die Transfektion des SW480-pcDNA6/TR1.7 mit pT-REx-DEST31-GFP. Die Selektionierung der transfizierten Zellen erfolgte direkt am nächsten Tag und wurde mit Genetizin durchgeführt.

Die Induzierbarkeit des pT-REx-DEST31-Vektors konnte zunächst mit einem Fluoreszenzmikroskop optisch bestimmt werden. Dafür wurden Zellen der heterogenen Population für 72 Stunden alle 24 Stunden mit $1 \mu \mathrm{g} / \mathrm{ml}$ Tetrazyklin induziert und unter dem Fluoreszenzmikroskop mit der uninduzierten Zellpopulation verglichen (siehe Abbildung 3.4).

Optisch konnte unter dem Mikroskop gezeigt werden, dass

- der Vektor induzierbar ist. Im Vergleich zu den uninduzierten Zellen zeigten die mit Tetrazyklin induzierten Zellen eine Grünfärbung.

- die Induktion eine relativ hohe Effizienz hat, da ein großer Anteil der Zellen grün gefärbt war. 
Durchlichtaufnahmen
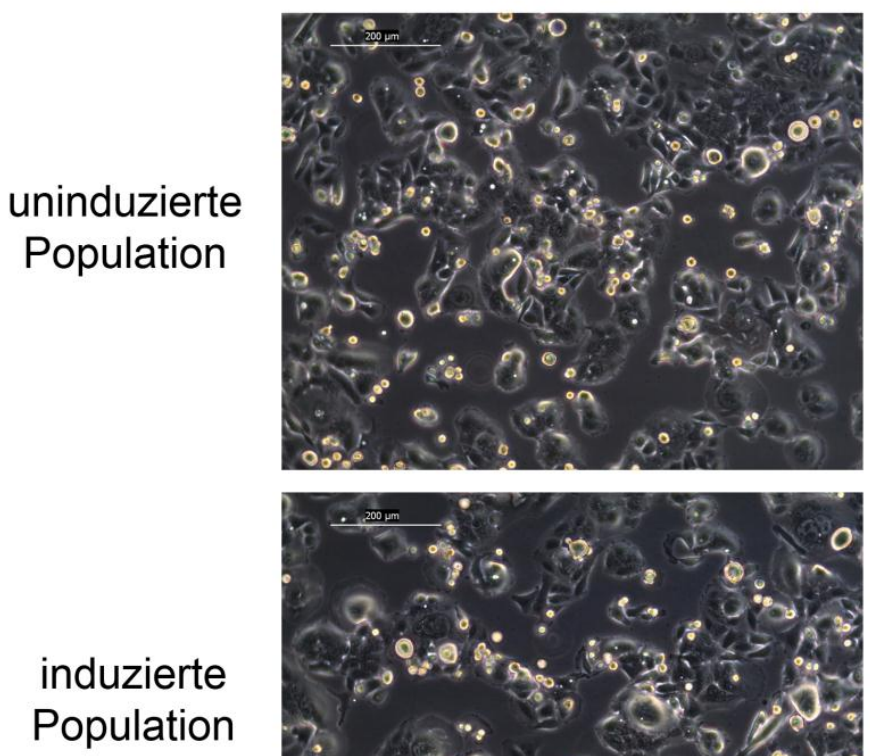

Abbildung 3.4: Mikroskopische Aufnahmen der heterogenen GFP-transfizierten SW480pcDNA6/TR1.7-Zellen

Vergleich zwischen der uninduzierten und der induzierten Population 72 Stunden nach Beginn der Induktion mit $1 \mu \mathrm{g} / \mathrm{ml}$ Tetrazyklin, Aufnahme mit dem Fluoreszenzmikroskop von Leica in 20facher Vergrößerung.

Dieses Resultat konnte durch fluoreszenzaktivierte Zellanalyse (FACS) genauer quantifiziert werden (siehe Abbildung 3.5). Hierzu wurden erneut Zellen der heterogenen GFP-transfizierten Population für 72 Stunden alle 24 Stunden mit $1 \mu \mathrm{g} / \mathrm{ml}$ Tetrazyklin induziert. Anschließend erfolgte die Messung dieser Zellpopulation sowie die einer uninduzierten GFP-transfizierten Population im FACS, bei der zuerst ein Gate auf die uninduzierten Zellen eingestellt wurde (siehe Abbildung 3.5A) und danach die GFPexprimierenden Zellen gemessen wurden. 
A

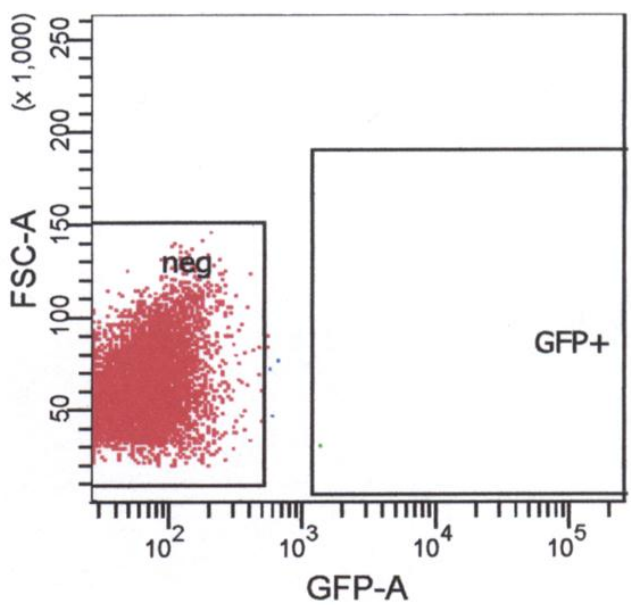

\begin{tabular}{|lrrr|}
\hline Tube: SW480_neg & & & \\
Population & \#Events & \%Parent & \%Total \\
\hline All Events & 10,000 & \#\#\# & 100.0 \\
$\square$ P1 & 9,591 & 95.9 & 95.9 \\
$\square$ P2 & 9,104 & 94.9 & 91.0 \\
& 9,003 & 98.9 & 90.0 \\
& 1 & 0.0 & 0.0 \\
& 8,999 & 100.0 & 90.0 \\
\hline neg & & & \\
\hline
\end{tabular}

B
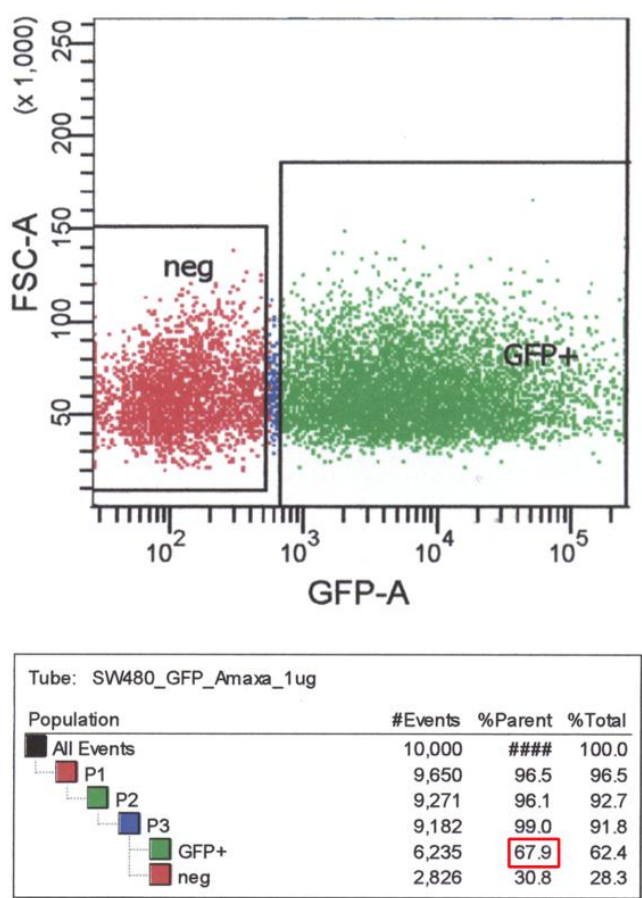

\section{Abbildung 3.5: FACS-Analyse der heterogenen GFP-transfizierten SW480pcDNA6/TR1.7-Zellen}

(A) uninduzierte Zellen der GFP-transfizierten Zelllinie SW480pcDNA6/TR1.7

(B) induzierte Zellen der GFP-transfizierten Zelllinie SW480pcDNA6/TR1.7.

Bei der FACS-Analyse waren in der uninduzierten Zellpopulation keine grün fluoreszierenden Zellen nachweisbar, was ein Hinweis dafür ist, dass ohne Zugabe von Tetrazyklin der GFP-Vektor von der Zelle nicht abgelesen wird. In der mit Tetrazyklin induzierten Zellpopulation hingegen wiesen $67,9 \%$ der Zellen ein grünes Fluoreszenzsignal auf (siehe Abbildung 3.5B).

Durch die FACS-Analyse konnte sichergestellt werden, dass der Vektor pT-REx-DEST31 in einer ausreichenden Menge von Zellen eingebaut wurde und das zu induzierende Zielgen abgelesen wird. Dies stellte die Grundvoraussetzung für eine funktionierende Überexpression der zu untersuchenden Gene NR3C1 und PDK4 dar. 
Um eine homogene Zellpopulation zu erhalten, in der der Vektor in jeder Zelle an der gleichen Stelle eingebaut und GFP in möglichst hohem Maße exprimiert wird, wurden analog Abschnitt 3.3.2 Einzelzellklone kultiviert (siehe Abbildung 2.4). Dabei entstanden sechs Klone.

A

His-tagged GFP

Aktin

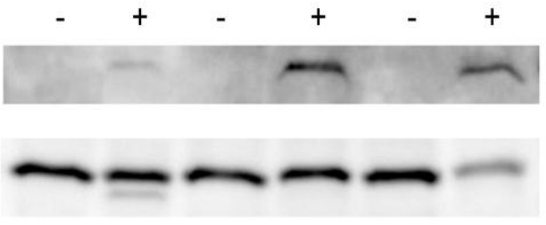

4.1

4.2

4.3

4.4

4.6

4.7

B

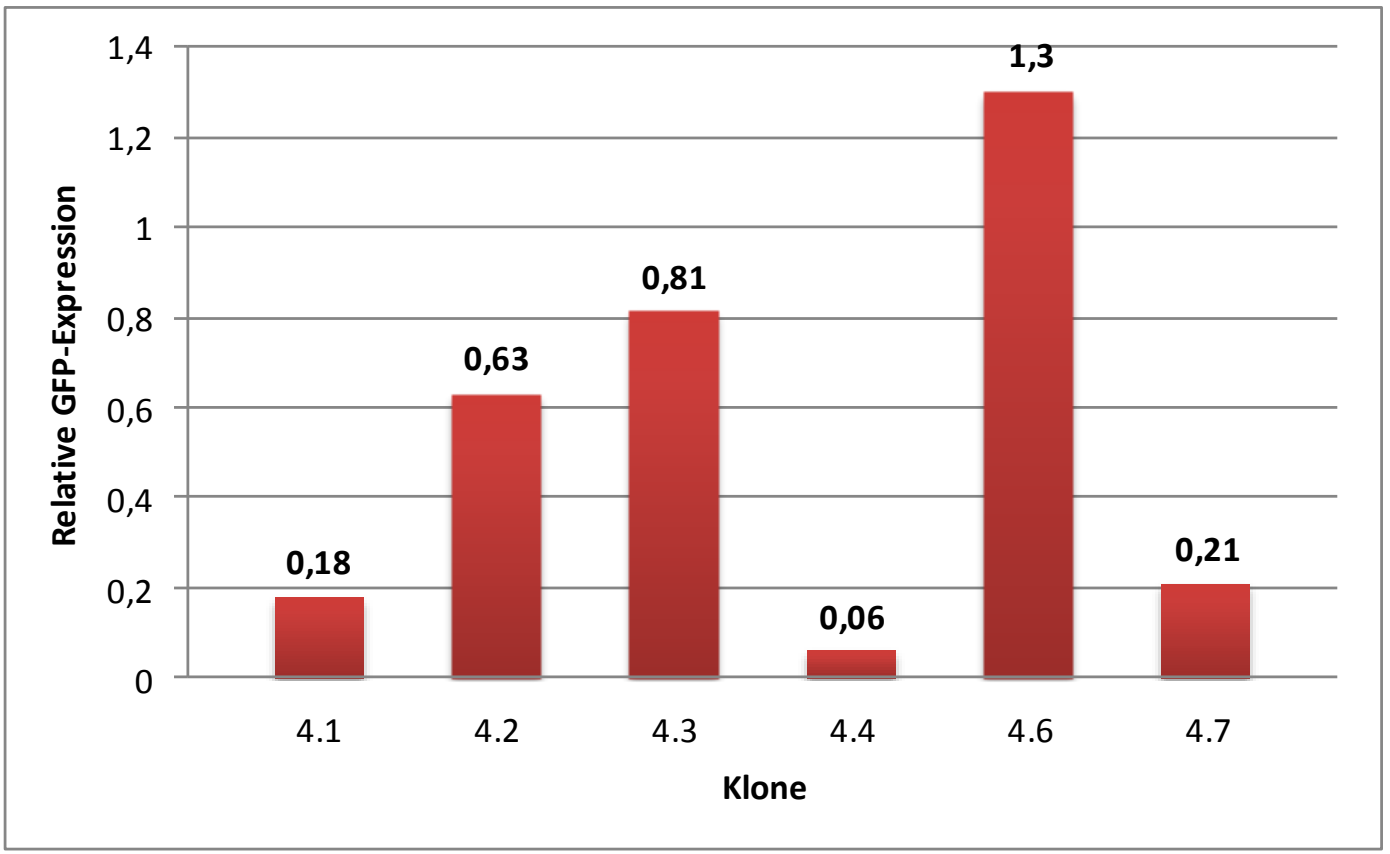

Abbildung 3.6: Die GFP-Expression in den Einzelzellklonen

A Western Blot mit GFP-Banden bei $30 \mathrm{kDa}$ und Aktin-Banden bei $42 \mathrm{kDa}$. Es wurde für jeden Klon eine uninduzierte neben eine mit Tetrazyklin induzierte Probe aufgetragen.

- = uninduziert, $+=$ induziert

B Grafische Darstellung der relativen GFP-Expression der Einzelzellklone. 
In Abbildung 3.6 sind die sechs mit GFP transfizierten Einzelzellklone mit ihrer relativen Proteinexpression dargestellt.

Die Proteinexpression von GFP wurde in jedem Klon durch einen Western Blot gegen das His-Tag geprüft, welches sich am N-terminalen Ende des überexprimierten GFP-Proteins befindet (siehe Abbildung 3.6A).

Alle Klone bis auf 4.4 zeigten eine GFP-Expression nach Induktion der Proteinexpression durch Tetrazyklin. Der Klon 4.6 wies im Western Blot die stärkste GFP-Expression auf und wurde somit als Kontrolle für die funktionellen Analysen verwendet.

\subsubsection{Herstellung von GR-überexprimierenden Zellen}

NR3C1 wurde wie GFP mit dem Vektorsystem pT-REx-DEST31 in den Tet-RepressorKlon 1.7 transfiziert. Durch die Einzelzellklonierung (siehe Abbildung 2.4) entstanden sieben Klone. Von jedem Klon wurde wiederum die mit Tetrazyklin induzierbare Proteinexpression mit der Western-Blot-Methode überprüft.

Das Protein wurde mit einem Antikörper gegen GR detektiert (siehe Abbildung 3.7A), da aus - zum Zeitpunkt der Erstellung dieser Arbeit ungeklärten Gründen - das His-TagFusionsprotein außer für GFP mit dem His-Tag-spezifischen Antikörper nicht zu detektieren war. Um das Ausmaß der Proteinexpression zu ermitteln, wurde aus der relativen GR-Expression der induzierten und der uninduzierten Zellklone ein Verhältnis gebildet (siehe Abbildung 3.7B) und die vier am besten zu induzierenden Klone 2.19, 2.20, 2.30 und 2.21 für die weiteren funktionellen Analysen verwendet. 


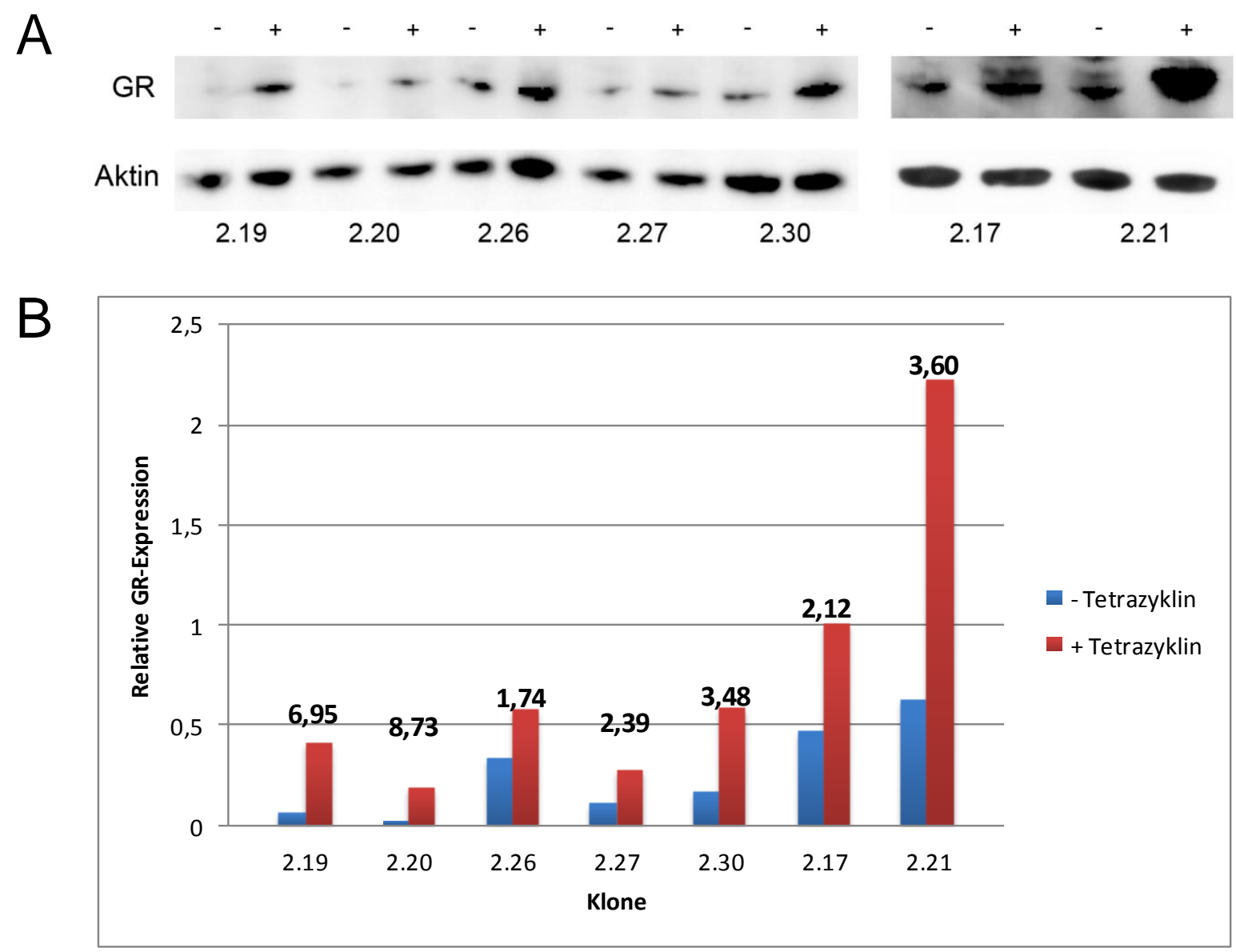

\section{Abbildung 3.7: Die GR-Expression in den Einzelzellklonen}

A Western Blot mit GR-Banden bei $97 \mathrm{kDa}$ und Aktin-Banden bei $42 \mathrm{kDa}$. Es wurde für jeden Klon eine uninduzierte neben eine mit Tetrazyklin induzierte Probe aufgetragen.

- = uninduziert, $+=$ induziert

B Grafische Darstellung der relativen GR-Expression der Einzelzellklone vor und nach Induktion mit Tetrazyklin. Die Zahl über den Säulen gibt das Vielfache der Überexpression von GR in den induzierten zu der in den uninduzierten Klonen an.

\subsubsection{Herstellung von PDK4-überexprimierenden Zellen}

Nach der Vektortransfektion von PDK4 in den Tet-Repressor-Klon 1.7 wurden die Einzelzellklone gesetzt (siehe Abbildung 2.4). Es entstanden sieben Klone, welche nach Tetrazyklin-Induktion zusammen mit den dazugehörigen uninduzierten Zellen auf den 
Western Blot aufgetragen wurden. Mit einem PDK4-Antikörper wurde das Protein detektiert (siehe Abbildung 3.8A).

A

PDK4

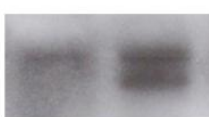

Aktin

5.1

5.2

5.3

5.4

5.5

5.6

5.9

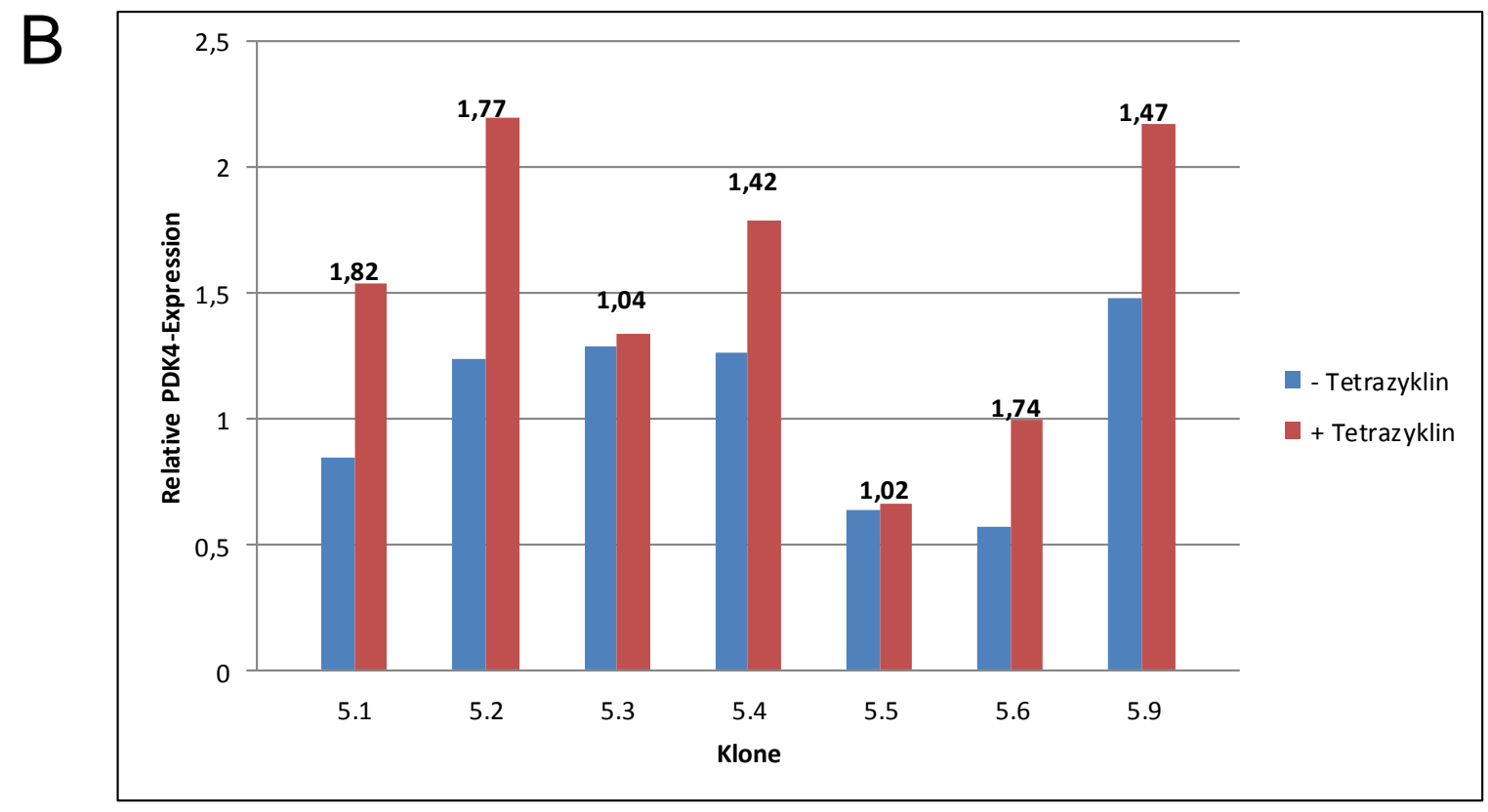

Abbildung 3.8: Die PDK4-Expression in den Einzelzellklonen

A Western Blot mit PDK4-Banden bei $46 \mathrm{kDa}$ und Aktin-Banden bei $42 \mathrm{kDa}$. Es wurde für jeden Klon eine uninduzierte neben eine mit Tetrazyklin induzierte Probe aufgetragen.

- = uninduziert, $+=$ induziert

B Grafische Darstellung der relativen PDK4-Expression der Einzelzellklone vor und nach Induktion mit Tetrazyklin. Die Zahl über den Säulen gibt das Vielfache der Überexpression von PDK4 in den induzierten zu der in den uninduzierten Klonen an. 
PDK4 zeigte eine hohe relative Grundexpression im Verhältnis zu Aktin. Es wurde jeweils das Verhältnis der Expression von der induzierten zu der uninduzierten Probe errechnet. Hierbei zeigten die Klone 5.1, 5.2, 5.6 und 5.9 die höchsten Expressionsunterschiede. Da 5.6 aus technischen Gründen nicht verwendet werden konnte, wurde stattdessen der Klon 5.4 mit den anderen oben genannten Klonen für weitere Versuche bestimmt.

\subsection{Viabilitätstest}

Durch Viabilitätsmessungen sollte geprüft werden, ob die experimentelle Hochregulierung von NR3C1 und PDK4 in der kolorektalen Zelllinie SW480 einen Effekt auf die Viabilität der Zellen hat.

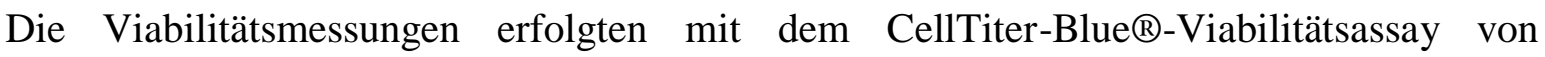
Promega. Dabei wurde die metabolische Aktivität von induzierten und uninduzierten, mit $N R 3 C 1$ bzw. PDK4 transfizierten, Zellen miteinander verglichen. Um zu zeigen, dass Veränderungen in der Viabilität nicht auf Effekte von Tetrazyklin beruhen, wurde der GFPKlon 4.6 bei jeder Messung als Kontrolle mitgeführt (siehe Abbildung 2.5). Die Viabilität wurde durch eine einstündige Inkubation des CellTiter-Blue®-Reagenz für GFP-Zellen und die jeweiligen vier Klone beider Gene nach jeweils 72 und 96 Stunden in einem Plattenlesegerät bei einer Extinktion von $595 \mathrm{~nm}$ bestimmt. Die Messung wurde mit sechs technischen Replikaten von jedem Klon durchgeführt und daraus der Mittelwert errechnet. Die vier Klone, in denen jeweils entweder $N R 3 C l$ oder PDK4 hochreguliert waren, stellten biologische Replikate dar, aus deren Messergebnissen ebenfalls der Mittelwert gebildet wurde. Der Wert der uninduzierten Zellen wurde jeweils auf $100 \%$ gesetzt und davon ausgehend die Viabilität der induzierten Zellen bestimmt. Dies entspricht der normalisierten Zellviabilität. Aus Gründen der Übersichtlichkeit wurden nicht die absoluten Werte verglichen, da die Viabilität der mit NR3C1, PDK4 und GFP transfizierten Zellen schon im uninduzierten Zustand sehr unterschiedlich waren. 
Die Ergebnisse nach 72 Stunden sind in Abbildung 3.9A, nach 96 Stunden in Abbildung 3.9B dargestellt.
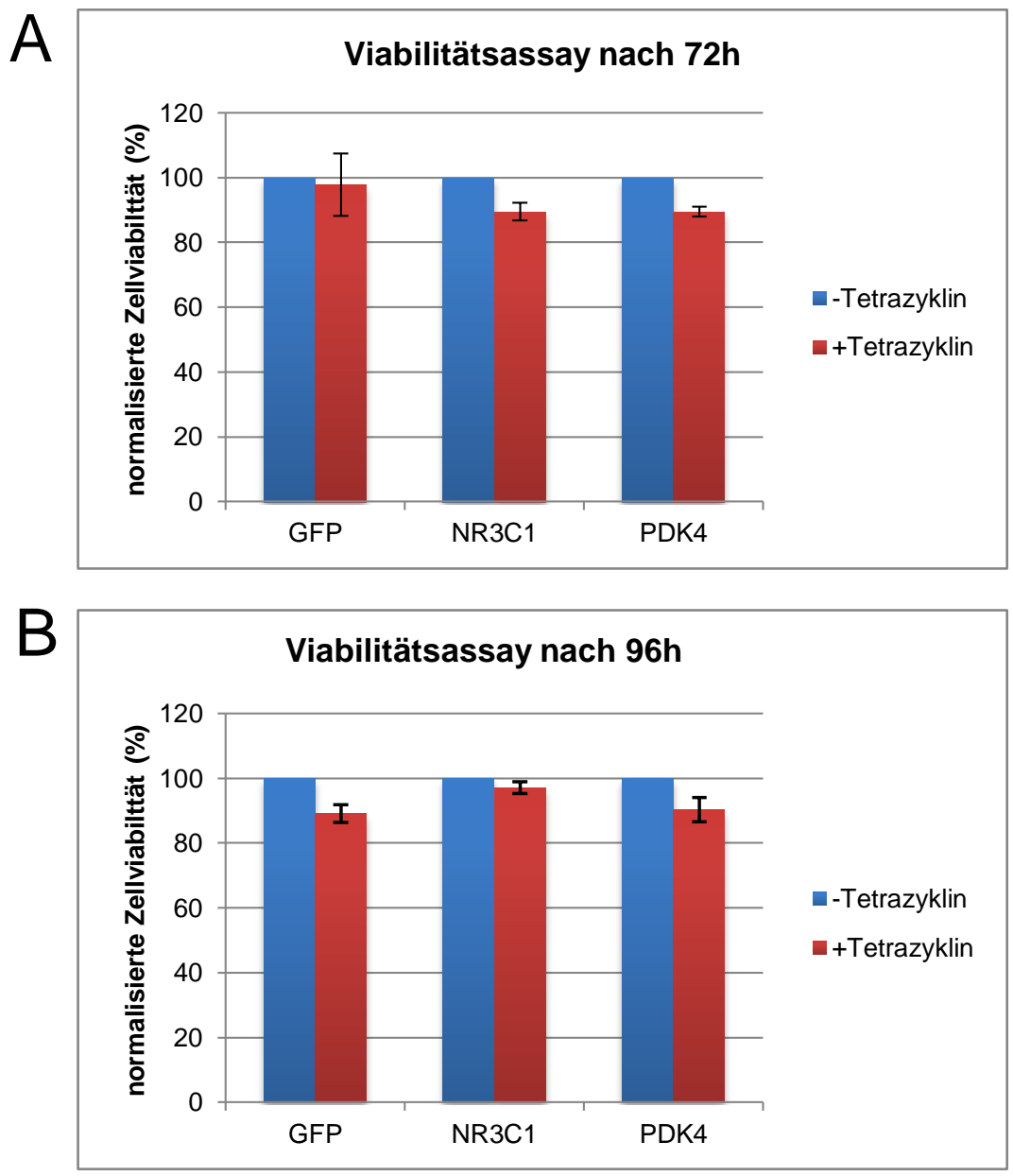

\section{Abbildung 3.9: Viabilitätstest der Überexpressionsklone}

(A) Viabilitätsmessung der Zellen 72 Stunden nach Induktion

(B) Viabilitätsmessung der Zellen 96 Stunden nach Induktion.

Die normalisierte Viabilität der uninduzierten Zellen ist mit blauen Balken dargestellt, die der mit Tetrazyklin induzierten Zellen mit roten Balken. Die Fehlerbalken repräsentieren den Standard Error of the Mean (SEM).

Bei den GR-überexprimierenden Zellen zeigte sich nach 72 Stunden eine durchschnittliche Viabilitätsreduktion auf 89,5\% und nach 96 Stunden eine Verminderung auf 97,1\%. Im 
Vergleich zwischen der 72- und der 96-Stunden-Messung fällt ein Anstieg der durchschnittlichen normalisierten Zellviabilität auf.

Die vier PDK4-Klone wiesen nach 72 Stunden eine verminderte durchschnittliche normalisierte Zellviabilität von 89,5\% auf. Nach 96 Stunden betrug die durchschnittliche normalisierte Zellviabilität 90,3\%. Vergleicht man hier die nach 72 und die nach 96 Stunden durchgeführten Messungen, ist keine maßgebliche Veränderung der durchschnittlichen normalisierten Zellviabilität festzustellen.

Für die GFP-Kontrollzellen wurde eine mittlere normalisierte Zellviabilität von 97,8\% nach 72 Stunden und 89,1\% nach 96 Stunden errechnet.

Es konnten nach Induktion der Überexpression beider Gene keine signifikanten Veränderungen in der Viabilität festgestellt werden.

\subsection{Koloniebildungstest}

Mit dem Koloniebildungstest wird bestimmt, ob eine einzelne Zelle die Fähigkeit besitzt, sich zu teilen und wieder eine Kolonie zu bilden. Aus Vorversuchen war bekannt, dass die parentale Zelllinie SW480 in der Lage ist, Kolonien aus Einzelzellen zu bilden. Es sollte in diesem Versuch geprüft werden, ob die experimentelle Hochregulierung der Genexpression von NR3C1 und PDK4 diese Fähigkeit verändert.

Für den Versuch wurden die entsprechenden Zell-Klone auf eine Sechs-Well-Platte ausgesetzt. Drei der Wells wurden täglich mit $1 \mu \mathrm{g} / \mathrm{ml}$ Tetrazyklin induziert, die anderen drei Wells blieben uninduziert (siehe Abbildung 2.6). Somit wurden jeweils drei technische Replikate der uninduzierten bzw. der induzierten Zellen eines Klons ausgesetzt. Die vier Klone, in denen jeweils NR3C1 oder PDK4 hochreguliert waren, stellten biologische Replikate dar. Zum Ausschluss von Effekten des Antibiotikums auf die Koloniebildung wurde der GFP-Klon 4.6 als Kontrolle mitgeführt. Die Ergebnisse des Versuches sind in Abbildung 3.10 für NR3C1 und PDK4 dargestellt. Die gezählte Koloniezahl in den Wells der mit Tetrazyklin induzierten Zellen wurde in Verhältnis zu denen der uninduzierten 
Zellen gesetzt, wobei dieser Wert jeweils auf $100 \%$ gesetzt wurde. Dies entspricht der normalisierten Koloniezahl.

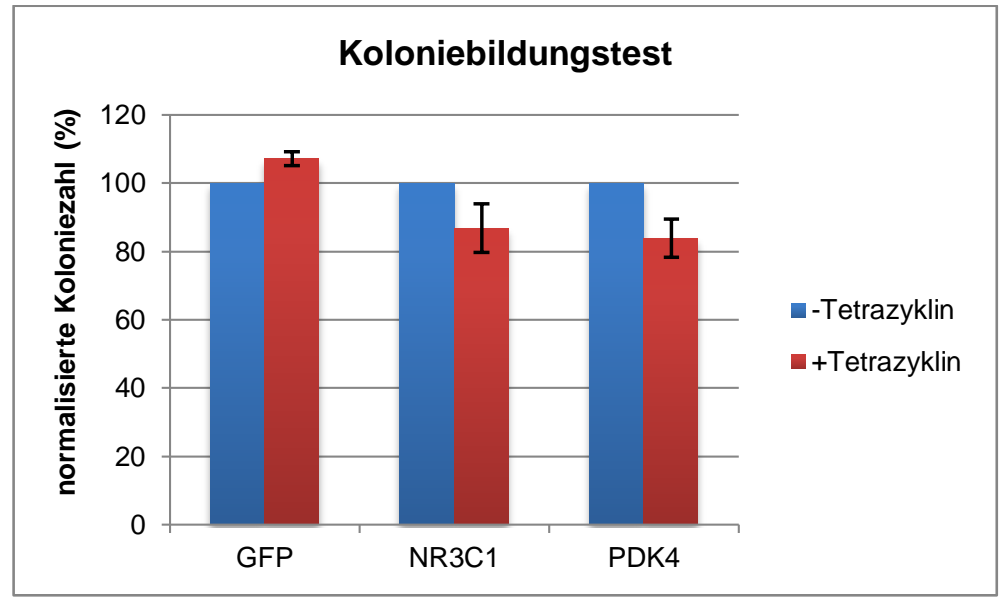

\section{Abbildung 3.10: Koloniebildungstest der Überexpressionsklone}

Die normalisierte Koloniezahl der uninduzierten Zellen ist mit blauen Balken dargestellt, die der mit Tetrazyklin induzierten Zellen mit roten Balken. Die Fehlerbalken repräsentieren den Standard Error of the Mean (SEM).

GR-überexprimierende Zellen zeigten im Vergleich zur GFP-Kontrolle eine durchschnittliche verringerte Kolonieanzahl auf 85,7 \% im Vergleich zu den uninduzierten Zellen.

Eine Überexpression von PDK4 in SW480 führte zu einer durchschnittlichen Reduktion der Kolonieanzahl auf 83,1 \% im Vergleich zur GFP-Kontrolle.

Für die Kontrolle GFP-Klon 4.6 ergab sich eine durchschnittliche relative Koloniezahl von $110,8 \%$ im Vergleich zu den uninduzierten Zellen. 


\section{Diskussion}

Obwohl das kolorektale Karzinom als eines der am intensivsten untersuchten humanen Malignome gilt, besteht nach wie vor großes klinisches Interesse daran, die zugrundeliegenden Mechanismen der Karzinogenese und relevante molekulare Signalwege zu entschlüsseln. Denn trotz Optimierung chirurgischer Operationstechniken und Etablierung effektiver (neo-) adjuvanter Therapiestrategien entwickeln ungefähr $25 \%$ bis $50 \%$ der Patienten im Verlauf Lebermetastasen (Meyerhardt und Mayer 2005; Khatri et al. 2005; Andre und Schmiegel 2005). Es gilt daher, die therapeutischen Optionen durch Entwicklung neuer antitumoraler Substanzen $\mathrm{zu}$ verbessern und zudem eine “personalisierte Medizin” zu etablieren, um Patienten auf der Basis spezifischer biologischer Tumoreigenschaften zu behandeln.

Ziel dieser Arbeit ist daher, ausgewählte Gene, die von unserer Arbeitsgruppe in vorherigen Genexpressionsanalysen identifiziert worden waren (Grade et al. 2007), auf ihre mögliche Relevanz für das Wachstum und die Proliferation kolorektaler Tumorzellen zu untersuchen. Hierzu wurde initial die Expression von sechs Genen, welche in den Genexpressionsexperimenten eine verminderte Expression in Primärtumoren im Vergleich zur normalen Mukosa zeigten, mittels semi-quantitativer real-time-PCR überprüft. Die PCR-Validierung bestätigte für fünf von sechs Genen die verminderte Expression in allen sechs untersuchten kolorektalen Zelllinien. Zwei dieser Gene, PDK4 und NR3C1, wurden nachfolgend in der Kolonkarzinom-Zelllinie SW480 stabil überexprimiert, um funktionelle Analysen anschließen zu können (Viabilitätsmessungen und Koloniebildungstests). Die jeweiligen Einzelzellklone beider Gene zeigten im CellTiter-Blue ${ }^{\circledR}$-Test keine signifikante Reduktion der Viabilität. Im Koloniebildungstest wiesen sie allerdings eine reduzierte Fähigkeit auf, entsprechende Kolonien zu bilden. 


\subsection{Genexpressionsanalysen kolorektaler Tumoren}

Durch genetische und epigenetische Alterationen wird die Genexpression in Tumoren im Vergleich zum gesunden Gewebe verändert. Diese Veränderungen können in einer Genexpressionsanalyse gemessen werden. Ziel ist es, mögliche molekulare Grundlagen zu entdecken und Faktoren $\mathrm{zu}$ identifizieren, die die Tumorentwicklung initiieren und vorantreiben. Ein mögliches Verfahren dazu stellt die Mikroarray-Technologie dar. In einem Mikroarray-Experiment kann die Expression tausender Gene gleichzeitig analysiert werden (Mello-Coelho und Hess 2005).

Mikroarray-Experimente weisen jedoch eine Reihe potentieller Fehlerquellen auf, wie zum Beispiel die heterogene RNA-Qualität der Primärtumoren, fehlerhafte cDNA-Bibliotheken, Artefakte, Kreuzhybridisierung zwischen ähnlichen Substanzen und fehlerhafte Intensitätsmessungen (Koizumi 2004). Daraus erschließt sich die Notwendigkeit einer Validierung der Mikroarray-Experimente mithilfe alternativer Methoden wie beispielsweise der PCR (Brown und Botstein 1999; Rajeevan et al. 2001).

Seit der Entwicklung des Mikroarrays wurden viele Studien zu Genexpressionsunterschieden zwischen kolorektalem Tumorgewebe und gesunder Mukosa durchgeführt, so zum Beispiel von Alon et al. 1999, Notterman et al. 2001, Williams et al. 2003, Bianchini et al. 2006 und Grade et al. 2006 und 2007. Obwohl eine große Zahl differenziell exprimierter Gene bei diesen Experimenten identifiziert wurde, konnten bisher noch keine verlässlichen Biomarker oder spezifische Sequenzen mit klinischer Relevanz für die molekulare Diagnose oder die Klassifizierung von kolorektalen Karzinomen gefunden werden (Joyce und Pintzas 2007; Nannini et al. 2009). Eine wichtige Voraussetzung für die Identifikation solcher potentiellen Zielgene stellt die Validierung der differentiell exprimierten Gene mithilfe funktioneller Analysen beispielsweise in Karzinomzelllinien dar. 


\subsection{PCR-Validierung in Zelllinien}

Die im Mikroarray-Experiment gemessene verminderte Expression der beschriebenen Gene in kolorektalen Karzinomen sollte in dieser Arbeit mithilfe der semi-quantitativen real-time-PCR in kolorektalen Karzinomzelllinien validiert werden. Zwar stellen Zelllinien ein verlässliches Modell der genetischen und phänotypischen Veränderungen des entsprechenden Primärtumors dar, jedoch ist eine Validierung sowohl eine Voraussetzung als auch eine Absicherung für das weitere experimentelle Vorgehen (Dallas et al. 2005). Für die PCR-Validierung wurden die kolorektalen Zelllinien SW480, SW1116, Caco-2, LS513 und HT-29 ausgewählt.

Die Ergebnisse der semi-quantitativen real-time-PCR zeigen, dass alle Gene bis auf $C A 5 A$ in den fünf Zelllinien herunterreguliert sind. Dies bestätigt das Mikroarray-Ergebnis und unterstützt zudem die Theorie, dass das Zelllinienmodell die genetischen Gegebenheiten des Primärtumors repräsentiert. Allerdings fällt auf, dass die Fold Changes der Genexpression von Tumorproben zur gesunden Mukosa im Mikroarray wesentlich höher sind als die Fold Changes der Genexpression von Zelllinien zur gesunden Mukosa in der semi-quantitativen real-time-PCR. $\mathrm{Zu}$ berücksichtigen ist dabei, dass nach der Probenentnahme vom Patienten die Tumorproben für den Mikroarray Verunreinigungen durch andere Zellen, wie beispielsweise Stromazellen und weitere Nicht-Tumoranteile enthalten können, welche dann das Mikroarray-Signal verändern. Die Zelllinien hingegen sind reine Tumorzellpopulationen, bei denen keine Verunreinigungen der gemessenen Zellliniensignale durch Fremdzellen zu erwarten sind. Das Signal der Tumorproben kann außerdem durch Reaktionen des Tumors mit seinem Mikroumfeld anders sein als das der Zelllinien im Kulturmedium.

CA5A ist als einziges der sechs validierten Gene in den Zelllinien SW1116, Caco-2, LS513 und HT-29 stärker exprimiert als in der Normalmukosa. Diese Abweichung könnte wie folgt begründet werden:

1. Es liegt eine Fehlkonstruktion des Primers vor.

2. Nach Isolation aus dem Primärtumor ist es durch die in-vitro-Kultivierung der Zelllinien zu Mutationen in diesem Gen gekommen. 
3. Die Expression des Gens wurde in den Tumorproben durch verunreinigende Fremdzellen beeinflusst.

4. Es liegt ein Messfehler in der semi-quantitativen real-time-PCR vor.

5. Es liegt ein Messfehler im Mikroarray vor.

\subsection{Beschreibung der Zielgene}

Zunächst wurde aus dem vorangegangenen Mikroarray-Experiment von allen potentiellen Zielgenen die Auswahl auf zwei Gene eingegrenzt, die für die funktionellen Analysen verwendet werden sollten. Diese Gene (PDK4 und NR3C1) sind in der Literatur gut charakterisiert, wobei relativ wenige Daten für das kolorektale Karzinom vorliegen.

\subsubsection{NR3C1}

NR3C1 ist auf Chromosom 5 lokalisiert und kodiert für den ubiquitär exprimierten Glukokortikoid-Rezeptor (GR), der sowohl selbst als Transkriptionsfaktor fungieren als auch andere Transkriptionsfaktoren regulieren kann. Der Rezeptor ist zunächst im Zytoplasma lokalisiert und wird dann durch einen Liganden (ein Glukokortikoid) induziert und in den Kern transloziert (Nicolaides et al. 2010). Durch die Aktivierung von GR werden wiederum Gene in verschiedenen Zelltypen reguliert, welche in Prozesse wie die Unterdrückung von Inflammation und die Entwicklung verschiedener Gewebe involviert sind (Biddie und Hager 2009).

Es ist bekannt, dass GR in einigen Tumoren unterschiedlich exprimiert wird. In kleinzelligen Lungenkarzinomen konnte beispielsweise eine reduzierte GR-Expression nachgewiesen werden. Die GR-Expression wirkt hier pro-apoptotisch (Sommer et al. 2007). Brustkrebs hingegen ist mit einer Akkumulation von GR im Zytoplasma assoziiert (Conde et al. 2008). 
$\mathrm{Zu}$ der Expression von GR im kolorektalen Karzinom gibt es widersprüchliche Studienergebnisse. So konnten beispielsweise Lien et al. in kolorektalen Adenokarzinomen mithilfe immunhistochemischer Verfahren kein GR nachweisen, während sich im umgebenden mesenchymalen Gewebe eine starke Expression zeigte (Lien et al. 2008). Bei Theocharis et al. hingegen wiesen - ebenfalls in der Immunhistochemie - $50 \%$ der untersuchten kolorektalen Karzinome eine GR-Expression auf (Theocharis et al. 2003). Diese Ergebnisse könnten jedoch durch eine Kontamination mit mesenchymalen Zellen begründet sein.

In weiteren Studien wurde eine epigenetische Deregulierung von NR3C1 in Form einer Hypermethylierung in mikrosatelliteninstabilen kolorektalen Karzinomen beobachtet (Lind et al. 2006; Ahlquist et al., 2008).

In den Mikroarray-Experimenten von Grade et al. zeigte sich eine Verminderung der Genexpression von $\mathrm{NR} 3 \mathrm{Cl}$ in Kolonkarzinomen im Vergleich zur gesunden Mukosa (Grade et al. 2007). Dieses Ergebnis konnte in der vorliegenden Arbeit mithilfe der PCRValidierung in kolorektalen Zelllinien bestätigt werden.

Das Ausmaß der GR-Expression korreliert weder mit Stadium, Lokalisation, Differenzierung und Metastasierung des Tumors noch mit der Überlebenswahrscheinlichkeit des Patienten. Es wird vermutet, dass GR im biologischen Mechanismus der Entstehung des kolorektalen Karzinoms eine Rolle spielt, wenngleich der zugrundeliegende Mechanismus noch nicht bekannt ist (Theocharis et al. 2003).

\subsection{2. $P D K 4$}

PDK4 ist auf Chromosom 7 gelegen und kodiert für ein mitochondriales Protein mit einer Histidin-Kinase-Domäne. Als eines von vier Isoenzymen (PDK1-4) phosphoryliert und inaktiviert es den Pyruvat-Dehydrogenase-Komplex (PDC) und reguliert dadurch den Glukose-Metabolismus (Connaughton et al. 2010). Durch Hemmung der mitochondrialen Atmungskette wird die anaerobe Glykolyse aktiviert. Diesen Mechanismus machen sich eine Reihe von Tumoren im sogenannten „Warburg-Metabolismus“ zu Nutze. Im WarburgMetabolismus wird die Aktivität des PDC heruntergefahren, unabhängig davon, ob aerobe 
oder anaerobe Bedingungen vorliegen (McFate et al. 2008). Dies geschieht vermutlich durch verstärkte Signalisierung des hypoxia inducible factor (HIF) in Tumorzellen. Dadurch wird eine Überexpression von PDK1 induziert, welche wiederum die Aktivität des PDC hemmt (Kim und Dang 2006; Roche und Hiromasa 2007). Über die Rolle von PDK4 im Warburg-Metabolismus ist bis dato jedoch noch nichts bekannt. Auch auf die Frage, warum der Tumor die Umwandlung von Glukose in Laktat der effizienteren aeroben Glykolyse vorzieht, gibt es noch keine abschließende Antwort (Yeluri et al. 2009).

PDK4 kommt vor allem in Herz- und Muskelzellen vor, wird jedoch auch in den meisten anderen Geweben bei Hungerzuständen und bei Patienten mit Diabetes mellitus verstärkt exprimiert (Patel und Korotchkina 2002; Sugden und Holness 2003; Kwon und Harris 2004). Bei Herzversagen wird die PDK4-Expression vermindert (Razeghi et al. 2002). Die Inhibition von PDK4 wird als potentielle Therapiemöglichkeit für Adipositas und Diabetes mellitus Typ II diskutiert (Wynn et al. 2008).

Die Informationen aus der Literatur hätten primär vermuten lassen, dass die PDK4Expression im kolorektalen Karzinom hochreguliert wäre, falls sie als Teil des PDK Enzymkomplexes im Warburg-Metabolismus eine Rolle spielen würde. Die Ergebnisse der vorangegangenen Genexpressionsanalyse unserer Arbeitsgruppe (Grade et al. 2007), sowie die PCR-Validierung in dieser Arbeit zeigen jedoch eine signifikante Herunterregulation von PDK4 im kolorektalen Karzinom bzw. in den untersuchten kolorektalen Zelllinien. Eine mögliche Erklärung hierfür könnte sein, dass der Warburg-Metabolismus in den untersuchten Tumoren und Zelllinien eine untergeordnete Rolle spielt oder dass PDK4 entgegen aller Vermutung nicht am Warburg-Metabolismus beteiligt ist.

\subsection{Funktionelle Analysen}

Allein die Tatsache, dass ein Gen in gesunder Mukosa und kolorektalem Karzinom unterschiedlich stark exprimiert wird, bedeutet natürlich nicht notwendigerweise, dass es damit eine kausale Bedeutung für das Wachstum von Tumorzellen hat oder gar ein potentielles therapeutisches Zielgen darstellt. Dies muss zunächst in einer funktionellen 
Validierung überprüft werden. Hierbei wird zum Beispiel untersucht, ob die Änderung des Expressionsstatus eines bestimmten Gens in einer Zelllinie zu einem veränderten Verhalten der Zellen führt.

\subsubsection{Verwendung des Zelllinienmodells}

Zelllinien stellen ein geeignetes Modell für funktionelle Analysen dar, da von Tumoren abgeleitete Zelllinien viele Merkmale des Primärtumors aufweisen. Am Beispiel des Brustkrebses konnte gezeigt werden, dass Zelllinien die genomische Komplexität des Tumors widerspiegeln (Neve et al. 2006). Entgegen der weit verbreiteten Annahme führt die ex vivo Kultivierung nicht zu einer Anhäufung artifizieller genomischer Aberrationen. Wichtige Tumorsuppressorgene und Onkogene, unter anderem KRAS, wurden sogar initial durch die Analyse von Tumorzelllinien identifiziert (Solomon et al. 2009). Doch die Verwendung von Zellkulturen bringt auch Risiken und Nachteile mit sich. Die Ergebnisse von Zellkulturexperimenten können zum Beispiel durch eine hohe Anzahl von Passagierungen und durch die Kontamination mit Bakterien, Pilzen, Viren oder anderen Zelllinien verfälscht werden. Dies sollte durch sauberes Arbeiten und die regelmäßige Kontrolle von Morphologie und Wachstumsverhalten vermieden werden (Reid 2011). Zusätzlich zur Einhaltung dieser Grundregeln wurden in dieser Arbeit die kultivierten Zelllinien regelmäßig auf Mykoplasmen getestet. Zu Beginn der Experimente wurde außerdem ein short-tandem-repeat-Profiling durchgeführt, welches die Identität der Zelllinien bestätigte und eine Kontamination ausschloss.

Ein Beispiel der Verwendung des Zelllinienmodells im Rahmen funktioneller Analysen ist die Anwendung der RNA-interference (RNAi)-Technologie. Hierbei können Gene in Karzinomzelllinien herunterreguliert werden, die sich in vorherigen Genexpressionsanalysen als überexprimiert gezeigt haben. Durch diese Methode konnten bereits potentielle therapeutische Zielgene für das kolorektale Karzinom identifiziert werden (Williams et al. 2003; Grade et al. 2011). In der vorliegenden Arbeit wurden im Gegensatz dazu solche Gene, die in den Genexpressionsprofilen von Primärtumoren herunterreguliert waren, durch die Anwendung von Überexpressionsvektoren in Zelllinien 
hochreguliert. Die Anwendung von induzierbaren Überexpressionsvektoren in Zelllinien sollte dabei als neue Methode im Labor etabliert werden. Ziel war es, stabil transfizierte Zellklone $\mathrm{zu}$ entwickeln und deren Induzierbarkeit sicherzustellen, um eine Basis für weitere funktionelle Experimente zu schaffen.

Aufgrund der Beschränkung von Zeit und Ressourcen im Rahmen dieser Doktorarbeit wurde die Überexpression von GR und PDK4 auf eine Zelllinie beschränkt. Die Experimente sollten in SW480 durchgeführt werden, da diese Zelllinie im Labor bereits gut für Transfektionen und funktionelle Experimente etabliert war. Zudem zeigte sich auch hier für PDK4 und NR3C1 eine deutliche Herunterregulation in der semi-quantitativen real-time-PCR. Da SW480 eine mikrosatellitenstabile Zelllinie ist, repräsentiert sie die am häufigsten vertretene Art der genetischen Instabilität im kolorektalen Karzinom und stellt ein ideales Zelllinienmodell für diese funktionellen Untersuchungen dar.

\subsubsection{Etablierung von stabil überexprimierenden Zelllinien}

Zur Etablierung der stabilen Überexpressionszelllinien wurde zunächst der Tet-RepressorVektor in SW480 transfiziert. Nach Selektionierung wurden dann Einzelzellklone gezüchtet, wobei derjenige Zellklon weiter verwendet wurde, bei welchem die höchste Proteinexpression nachgewiesen werden konnte. Der Western Blot nach Vektorinduktion zeigte, dass die Einzelzellklone den Tet-Repressor jeweils unterschiedlich stark exprimieren. Zwei der Einzelzellklone (1.5 und 1.12) wiesen nahezu keine Expression auf. Das lässt sich durch den zufälligen Einbau des Vektorsystems ins Genom erklären. Wird der Vektor beispielsweise in ein Intron oder ein selten abgelesenes Exon integriert, ist die Ablesungsrate dementsprechend niedriger und es wird weniger Tet-Repressor exprimiert.

Da die Expression des Tet-Repressors eine Voraussetzung für die Expression der Vektoren mit den Zielgenen PDK4 und NR3C1 darstellt, wurde für weitere Experimente der Einzelzellklon mit der stärksten Tet-Repressor-Expression (1.7) gewählt.

Der Western Blot wurde als Analysemethode zur Klonauswahl verwendet, da er im Gegensatz zur semi-quantitativen real-time-PCR die Expression auf Proteinebene zeigt. Nachteile dieser Methode sind jedoch die schwierige Quantifizierbarkeit der gemessenen 
Proteinlevel, der relativ hohe zeitliche und technische Aufwand, welcher oft Schwankungen in der Qualität verursacht, sowie die Notwendigkeit zur gründlichen Optimierung der Versuchsbedingungen für jeden Antikörper.

Durch stabilen Einbau von einem GFP-überexprimierenden Vektor in den durch Western Blot ausgewählten SW480-Tet-Repressor-Klon wurde eine heterogene Zellpopulation erzeugt, welche für die späteren funktionellen Experimente nach Durchlaufen einer Einzelzellklonierung für die Zielgene PDK4 und $N R 3 C 1$ als Negativkontrolle dienen sollte. Der Vergleich von induzierten zu uninduzierten Zellen dieser Population unter dem Fluoreszenzmikroskop sowie das Ergebnis der FACS-Analyse zeigt, dass in einem Großteil der Zellen der GFP-Vektor nach erfolgter Induktion abgelesen wird. Zellen, die nicht grün leuchten, haben entweder den GFP-Vektor an einer Stelle eingebaut, an dem er nicht abgelesen wird, oder aber die Induktion hat in diesen Zellen keine Effizienz gezeigt.

Die transfizierten Einzelzellklone für die beiden Zielgene zeigten eine relativ hohe Proteingrundexpression von PDK4 im Vergleich zu Aktin, wohingegen GR eine relativ niedrige Grundexpression aufwies. Das steht im Kontrast zu den Ergebnissen der semiquantitativen real-time-PCR, in der sich Fold Changes zwischen der Genexpression in SW480 im Vergleich zur gesunden Mukosa von 0,016 für NR3C1 und von 0,001 für PDK4 ergeben hatten. Eine mögliche Erklärung dafür wäre ein autonomes Ablesen der Vektoren in Abwesenheit von Tetrazyklin bzw. eine unzureichende intrazelluläre Menge an überexprimierten Tet-Repressor um den Promotor zu binden. Dies erscheint allerdings unter Berücksichtigung der Ergebnisse der Vorexperimente (FACS von uninduzierter GFPKontrollzelllinie) relativ unwahrscheinlich. Eine viel wahrscheinlichere Erklärung für diese Beobachtung ist das Vorhandensein von Artefakten im Western Blot oder Verunreinigungen der Einzelzellklone mit Tetrazyklin. Zudem basieren die errechneten Fold Changes auf PCR-Ergebnissen und beziehen sich somit auf die Expressionsmenge auf mRNA-Ebene, welche, wie bereits oben diskutiert, $\mathrm{zu}$ der Expressionsmenge auf Proteinebene variieren kann. Ein anderer Grund könnte die Verunreinigung der für die PCR-Validierung verwendete Mukosa-Probe mit mesenchymalen Zellen sein, für welche in der Literatur eine starke GR-Expression beschrieben wurde (Lien et al. 2008). 


\subsubsection{Viabilitätstest und Koloniebildungstest}

Um den Einfluss von GR und PDK4 auf die Viabilität der Zelllinie SW480 zu prüfen, wurde ein CellTiter-Blue ${ }^{\circledR}$ Cell Viability Assay jeweils 72 und 96 Stunden nach Beginn der Induktion mit Tetrazyklin durchgeführt. Doch weder die Überexpression von GR noch die von PDK4 hatte eine signifikante Auswirkung auf die Viabilität der kolorektalen Karzinomzelllinie SW480. Somit scheinen PDK4 und NRC3C1 keine besondere Bedeutung für das Wachstum kolorektaler Tumorzellen zu haben. Andererseits wäre es auch möglich, dass die Zeitspanne des Tests zu kurz für die Zellen ist, um eine ausreichende Menge des entsprechenden Proteins anzureichern, als dass sich ein Einfluss auf die Viabilität zeigen könnte. Eventuell muss zunächst eine Adaptation der Zelle an die erhöhte Proteinmenge und der Umbau von Signalwegen erfolgen, damit ein messbarer Effekt eintritt. Der Anstieg der gemessenen Viabilität zwischen dem 72- und dem 96-Stunden-Zeitpunkt lässt sich möglicherweise auf Messschwankungen zurückführen.

Um zu überprüfen, ob die Überexpression von PDK4 und GR einen Effekt auf die Koloniebildungsfähigkeit der Zelllinie SW480 ausübt, wurde ein Koloniebildungstest durchgeführt. Dabei zeigte sich eine Reduktion der Koloniebildungsfähigkeit der induzierten gegenüber den uninduzierten Zellen. Dieses Ergebnis ist zwar nicht signifikant, zeigt jedoch eine deutliche Tendenz hinsichtlich der Einschränkung der Koloniebildungsfähigkeit.

Die Viabilität sowie die Koloniebildungsfähigkeit repräsentieren Marker für die Malignität eines Zellklons. Je maligner eine Zelle ist, desto schneller und effektiver kann sie sich im umliegenden Gewebe ausbreiten, indem sie immer neue Kolonien bildet. Dabei ist ihr Metabolismus aktiver als der einer Zelle, die sich in niedrigerer Geschwindigkeit teilt. Es gibt noch eine Reihe weiterer Malignitätsmarker wie das Invasions- und Migrationsverhalten, die jedoch nicht im Rahmen dieser Arbeit überprüft werden konnten. 


\subsection{Ausblick}

Im Laufe dieser Arbeit konnten viele Fragen beantwortet und neue Erkenntnisse gewonnen werden, jedoch haben sich auch Probleme und Fragestellungen ergeben, über die in Zukunft nachgedacht werden muss. So bietet es sich an, weitere Tests, die zur Einschätzung der Malignität eines Zellklons eingesetzt werden können, an den etablierten Zellklonen durchzuführen. Hier könnte beispielsweise der sogenannte Scratch-Assay zum Einsatz kommen, mit dessen Hilfe die Migrationsfähigkeit eines Zellklons gemessen werden kann (Liang et al. 2007).

Durch die Validierung interessanter Zielgene, die Erstellung von stabil transfizierten Zellklonen und die Etablierung der benötigten Methoden konnte in dieser Arbeit der Grundbaustein für weitere Experimente mit dem Ziel der Überexpression interessanter Zielgene gelegt werden. Zudem konnte gezeigt werden, dass die Viabilität durch die Überexpression von GR und PDK4 nicht vermindert, die Koloniebildungsfähigkeit jedoch eingeschränkt wird. Das gibt erste Hinweise darauf, dass diese beiden Gene eine funktionelle Bedeutung für das kolorektale Karzinom haben könnten, und macht sie somit zu interessanten Genen für weitere Experimente. 


\section{Zusammenfassung}

Das kolorektale Karzinom ist die zweithäufigste Tumorerkrankung in Deutschland. Trotz der Etablierung neuer Therapiestrategien und stetiger Entwicklung in der Prävention und Früherkennung stellt das kolorektale Karzinom nach wie vor eine der häufigsten Krebstodesursachen dar.

Kolorektale Karzinome entstehen aus Zellen der Darmschleimhaut, in denen durch genetische Veränderungen Störungen der Differenzierung und der Wachstumskontrolle aufgetreten sind. Das Verständnis der molekularen Vorgänge in der Entstehung und der Progression des kolorektalen Karzinoms ist daher von großer Bedeutung und legt den Grundstein für die Entwicklung neuer Therapieansätze für die Behandlung des kolorektalen Karzinoms.

Das Ziel dieser Arbeit war die Untersuchung ausgewählter Gene auf ihre mögliche Bedeutung für das Wachstum und die Proliferation kolorektaler Tumorzellen. Diese Gene hatten in vorherigen Genexpressionsanalysen unserer Arbeitsgruppe eine verminderte Expression in Primärtumoren im Vergleich zur gesunden Mukosa gezeigt. Es wurde die Expression von insgesamt sechs Genen mittels semi-quantitativen real-time-PCR in kolorektalen Karzinomzelllinien überprüft. Die PCR-Validierung bestätigte die verminderte Expression für fünf von sechs Genen. Zwei dieser Gene, PDK4 und NR3C1, wurden nachfolgend in der kolorektalen Karzinomzelllinie SW480 mittels eines induzierbaren Vektorsystems stabil überexprimiert. Nach entsprechender Selektionierung und Einzelzellklonierung wurden anschließend mittels Western Blot diejenigen Klone identifiziert, die das entsprechende Gen am stärksten exprimieren. Diese wurden schließlich in funktionellen Analysen auf ihre Viabilität und Koloniebildungsfähigkeit untersucht.

Es konnte gezeigt werden, dass die Viabilität von SW480-Zellen weder durch die Überexpression von $N R 3 C 1$ noch von $P D K 4$ vermindert wird. Allerdings wird die Koloniebildungsfähigkeit eingeschränkt. Die Ergebnisse deuten darauf hin, dass sowohl NR3C1 als auch PDK4 eine funktionelle Bedeutung für das kolorektale Karzinom haben könnten. Weitere Untersuchungen sind hierzu notwendig. Durch die Etablierung der 
Methodik und die Herstellung entsprechender Einzelzellklone in dieser Arbeit konnte bereits die Grundlage für weitere Experimente in diesem Bereich geschaffen werden. 


\section{Literaturverzeichnis}

Ahlquist T, Lind GE, Costa VL, Meling GI, Vatn M, Hoff GS, Rognum TO, Skotheim RI, Thiis-Evensen E, Lothe RA (2008): Gene methylation profiles of normal mucosa, and benign and malignant colorectal tumors identify early onset markers. Mol Cancer $\underline{7}, 94$

Alberici P, Fodde R (2006): The role of the APC tumor suppressor in chromosomal instability. Genome Dyn $\underline{1}, 149-170$

Alon U, Barkai N, Notterman DA, Gish K, Ybarra S, Mack D, Levine AJ (1999): Broad patterns of gene expression revealed by clustering analysis of tumor and normal colon tissues probed by oligonucleotide arrays. Proc Natl Acad Sci U S A $\underline{96}, 6745-6750$

American Cancer Society: Cancer Facts \& Figures 2010. American Cancer Society, Atlanta 2010.

Andre N, Schmiegel W (2005): Chemoradiotherapy for colorectal cancer. Gut 54, 11941202

Arends JW (2000): Molecular interactions in the Vogelstein model of colorectal carcinoma. J Pathol $\underline{190}, 412-416$

Baker SJ, Preisinger AC, Jessup JM, Paraskeva C, Markowitz S, Willson JK, Hamilton S, Vogelstein B (1990): p53 gene mutations occur in combination with 17p allelic deletions as late events in colorectal tumorigenesis. Cancer Res $\underline{50}$, 7717-7722

Bellam N, Pasche B (2010): Tgf-beta signaling alterations and colon cancer. Cancer Treat Res 155, 85-103 
Bianchini M, Levy E, Zucchini C, Pinski V, Macagno C, De Sanctis P, Valvassori L, Carinci P, Mordoh J (2006): Comparative study of gene expression by cDNA microarray in human colorectal cancer tissues and normal mucosa. Int J Oncol 29, 83-94

Biddie SC, Hager GL (2009): Glucocorticoid receptor dynamics and gene regulation. Stress $\underline{12}, 193-205$

Bishop JM (1991): Molecular themes in oncogenesis. Cell ㄸ4, 235-248

Boland CR, Goel A (2010): Microsatellite instability in colorectal cancer. Gastroenterology $\underline{138}, 2073-2087$

Bradford MM (1976): A rapid and sensitive method for the quantitation of microgram quantities of protein utilizing the principle of protein-dye binding. Anal Biochem $\underline{72}, 248$ 254

Brown PO, Botstein D (1999): Exploring the new world of the genome with DNA microarrays. Nat Genet $\underline{21}, 33-37$

Calvert PM, Frucht H (2002): The genetics of colorectal cancer. Ann Intern Med 137, 603612

Chan AT, Giovannucci EL (2010): Primary prevention of colorectal cancer. Gastroenterology 138, 2029-2043 e2010

Conde I, Paniagua R, Fraile B, Lucio J, Arenas MI (2008): Glucocorticoid receptor changes its cellular location with breast cancer development. Histol Histopathol $\underline{23}, 77-85$ 
Connaughton S, Chowdhury F, Attia RR, Song S, Zhang Y, Elam MB, Cook GA, Park EA (2010): Regulation of pyruvate dehydrogenase kinase isoform 4 (PDK4) gene expression by glucocorticoids and insulin. Mol Cell Endocrinol 315, 159-167

Cunningham D, Atkin W, Lenz HJ, Lynch HT, Minsky B, Nordlinger B, Starling N (2010): Colorectal cancer. Lancet $\underline{375}, 1030-1047$

Dallas PB, Gottardo NG, Firth MJ, Beesley AH, Hoffmann K, Terry PA, Freitas JR, Boag JM, Cummings AJ, Kees UR (2005): Gene expression levels assessed by oligonucleotide microarray analysis and quantitative real-time RT-PCR -- how well do they correlate? BMC Genomics $\underline{6}, 59$

Edge SB, Byrd DR, Compton CC, Fritz AG, Greene FL, Trotti A, AJCC cancer staging manual, 7. Auflage; Springer, New York 2010.

Efeyan A, Serrano M (2007): p53: guardian of the genome and policeman of the oncogenes. Cell Cycle $\underline{6}, 1006-1010$

Fearon ER (2011): Molecular genetics of colorectal cancer. Annu Rev Pathol $\underline{6}, 479-507$

Fearon ER, Vogelstein B (1990): A genetic model for colorectal tumorigenesis. Cell $\underline{61}$, $759-767$

Franken NA, Rodermond HM, Stap J, Haveman J, Van Bree C (2006): Clonogenic assay of cells in vitro. Nat Protoc $1,2315-2319$

Gala M, Chung DC (2011): Hereditary colon cancer syndromes. Semin Oncol $\underline{38}$, 490-499

Galiatsatos P, Foulkes WD (2006): Familial adenomatous polyposis. Am J Gastroenterol $\underline{101}, 385-398$ 
Galizia G, Lieto E, Ferraraccio F, Orditura M, De Vita F, Castellano P, Imperatore V, Romano C, Ciardiello F, Agostini B, Pignatelli C (2004): Determination of molecular marker expression can predict clinical outcome in colon carcinomas. Clin Cancer Res $\underline{10}$, 3490-3499

Gollin SM (2005): Mechanisms leading to chromosomal instability. Semin Cancer Biol $\underline{15}$, $33-42$

Grade M, Ghadimi BM, Varma S, Simon R, Wangsa D, Barenboim-Stapleton L, Liersch T, Becker H, Ried T, Difilippantonio MJ (2006): Aneuploidy-dependent massive deregulation of the cellular transcriptome and apparent divergence of the Wnt/beta-catenin signaling pathway in human rectal carcinomas. Cancer Res $\underline{66}, 267-282$

Grade M, Hormann P, Becker S, Hummon AB, Wangsa D, Varma S, Simon R, Liersch T, Becker H, Difilippantonio MJ, Ghadimi BM, Ried T (2007): Gene expression profiling reveals a massive, aneuploidy-dependent transcriptional deregulation and distinct differences between lymph node-negative and lymph node-positive colon carcinomas. Cancer Res $\underline{67}, 41-56$

Grade M, Hummon AB, Camps J, Emons G, Spitzner M, Gaedcke J, Hoermann P, Ebner R, Becker H, Difilippantonio MJ, Ghadimi BM, Beissbarth T, Caplen NJ, Ried T (2011): A genomic strategy for the functional validation of colorectal cancer genes identifies potential therapeutic targets. Int J Cancer $\underline{128}, 1069-1079$

Grady WM (2004): Genomic instability and colon cancer. Cancer Metastasis Rev 23, 11-27

Grady WM, Carethers JM (2008): Genomic and epigenetic instability in colorectal cancer pathogenesis. Gastroenterology 135, 1079-1099 
Hampel H, Frankel WL, Martin E, Arnold M, Khanduja K, Kuebler P, Nakagawa H, Sotamaa K, Prior TW, Westman J, Panescu J, Fix D, Lockman J, Comeras I, De La Chapelle A (2005): Screening for the Lynch syndrome (hereditary nonpolyposis colorectal cancer). N Engl J Med $\underline{352}, 1851-1860$

Hanahan D, Weinberg RA (2000): The hallmarks of cancer. Cell 100, 57-70

Hanahan D, Weinberg RA (2011): Hallmarks of cancer: the next generation. Cell 144, 646674

Hernandez A, Smith F, Wang Q, Wang X, Evers BM (2000): Assessment of differential gene expression patterns in human colon cancers. Ann Surg 232, 576-585

Herold G: Innere Medizin 2011, 1. Auflage; Herold, Köln 2010, 480-482

Herzenberg LA, Sweet RG, Herzenberg LA (1976): Fluorescence-activated cell sorting. Sci Am 234, 108-117

Husmann G, Kaatsch P, Katalinic A, Bertz J, Haberland J, Kraywinkel K, Wolf U: Gesundheitsberichterstattung des Bundes - Krebs in Deutschland 2005/2006 - Häufigkeiten und Trends, 7. Auflage; Robert-Koch-Institut, Berlin 2010, 36-39.

Invitrogen: pT-REx-DEST Gateway ${ }^{\mathrm{TM}}$ Vectors Instruction Manual Version C; 25.Oktober 2010, www.invitrogen.com

Invitrogen: T-REx ${ }^{\mathrm{TM}}$ System User Manual Version G; 21.Oktober 2010, Www.invitrogen.com

Joyce T, Pintzas A (2007): Microarray analysis to reveal genes involved in colon carcinogenesis. Expert Opin Pharmacother $\underline{8}$, 895-900 
Khatri VP, Petrelli NJ, Belghiti J (2005): Extending the frontiers of surgical therapy for hepatic colorectal metastases: is there a limit? J Clin Oncol 23, 8490-8499

Kim JW, Dang CV (2006): Cancer's molecular sweet tooth and the Warburg effect. Cancer Res $\underline{66}, 8927-8930$

Knudson AG, Jr. (1971): Mutation and cancer: statistical study of retinoblastoma. Proc Natl Acad Sci U S A $\underline{68}, 820-823$

Koizumi S (2004): Application of DNA microarrays in occupational health research. J Occup Health $\underline{46}, 20-25$

Kwon HS, Harris RA (2004): Mechanisms responsible for regulation of pyruvate dehydrogenase kinase 4 gene expression. Adv Enzyme Regul 44, 109-121

Ladanyi M, Chan WC, Triche TJ, Gerald WL (2001): Expression profiling of human tumors: the end of surgical pathology? J Mol Diagn $\underline{3}$, 92-97

Laemmli UK (1970): Cleavage of structural proteins during the assembly of the head of bacteriophage T4. Nature $\underline{227}$, 680-685

Lampropoulos P, Zizi-Sermpetzoglou A, Rizos S, Kostakis A, Nikiteas N, Papavassiliou AG (2012): TGF-beta signalling in colon carcinogenesis. Cancer Lett $\underline{314}$, 1-7

Lengauer C, Kinzler KW, Vogelstein B (1998): Genetic instabilities in human cancers. Nature $\underline{396}, 643-649$

Leslie A, Carey FA, Pratt NR, Steele RJ (2002): The colorectal adenoma-carcinoma sequence. Br J Surg $\underline{89}$, 845-860 
Liang CC, Park AY, Guan JL (2007): In vitro scratch assay: a convenient and inexpensive method for analysis of cell migration in vitro. Nat Protoc $\underline{2}, 329-333$

Lien HC, Lu YS, Shun CT, Yao YT, Chang WC, Cheng AL (2008): Differential expression of glucocorticoid receptor in carcinomas of the human digestive system. Histopathology $\underline{52}$, 314-324

Lind GE, Kleivi K, Meling GI, Teixeira MR, Thiis-Evensen E, Rognum TO, Lothe RA (2006): ADAMTS1, CRABP1, and NR3C1 identified as epigenetically deregulated genes in colorectal tumorigenesis. Cell Oncol 28, 259-272

Lindl G: Zell- und Gewebekultur, 5. Auflage; Spektrum, Heidelberg 2002

Livak KJ, Schmittgen TD (2001): Analysis of relative gene expression data using real-time quantitative PCR and the 2(-Delta Delta C(T)) Method. Methods 25, 402-408

Loeb LA, Loeb KR, Anderson JP (2003): Multiple mutations and cancer. Proc Natl Acad Sci U S A $\underline{100}, 776-781$

Lynch HT, De La Chapelle A (1999): Genetic susceptibility to non-polyposis colorectal cancer. J Med Genet $\underline{36}$, 801-818

Markowitz SD, Bertagnolli MM (2009): Molecular origins of cancer: Molecular basis of colorectal cancer. N Engl J Med $\underline{361}$, 2449-2460

Marshall CJ (1991): Tumor suppressor genes. Cell ㄸ4, 313-326

Masters JR, Thomson JA, Daly-Burns B, Reid YA, Dirks WG, Packer P, Toji LH, Ohno T, Tanabe H, Arlett CF, Kelland LR, Harrison M, Virmani A, Ward TH, Ayres KL, 
Debenham PG (2001): Short tandem repeat profiling provides an international reference standard for human cell lines. Proc Natl Acad Sci U S A $\underline{98}, 8012-8017$

Mcfate T, Mohyeldin A, Lu H, Thakar J, Henriques J, Halim ND, Wu H, Schell MJ, Tsang TM, Teahan O, Zhou S, Califano JA, Jeoung NH, Harris RA, Verma A (2008): Pyruvate dehydrogenase complex activity controls metabolic and malignant phenotype in cancer cells. J Biol Chem 283, 22700-22708

Mello-Coelho V, Hess KL (2005): A conceptual and practical overview of cDNA microarray technology: implications for basic and clinical sciences. Braz J Med Biol Res $\underline{38}, 1543-1552$

Meyerhardt JA, Mayer RJ (2005): Systemic therapy for colorectal cancer. N Engl J Med $\underline{352}, 476-487$

Migliore L, Migheli F, Spisni R, Coppede F (2011): Genetics, cytogenetics, and epigenetics of colorectal cancer. J Biomed Biotechnol 2011, 792362

Mills AA (2005): p53: link to the past, bridge to the future. Genes Dev $\underline{19}$, 2091-2099

Nannini M, Pantaleo MA, Maleddu A, Astolfi A, Formica S, Biasco G (2009): Gene expression profiling in colorectal cancer using microarray technologies: results and perspectives. Cancer Treat Rev 35, 201-209

Neve RM, Chin K, Fridlyand J, Yeh J, Baehner FL, Fevr T, Clark L, Bayani N, Coppe JP, Tong F, Speed T, Spellman PT, Devries S, Lapuk A, Wang NJ, Kuo WL, Stilwell JL, Pinkel D, Albertson DG, Waldman FM, Mccormick F, Dickson RB, Johnson MD, Lippman M, Ethier S, Gazdar A, Gray JW (2006): A collection of breast cancer cell lines for the study of functionally distinct cancer subtypes. Cancer Cell $\underline{10}, 515-527$ 
Nicolaides NC, Galata Z, Kino T, Chrousos GP, Charmandari E (2010): The human glucocorticoid receptor: molecular basis of biologic function. Steroids $\underline{75}, 1-12$

Notterman DA, Alon U, Sierk AJ, Levine AJ (2001): Transcriptional gene expression profiles of colorectal adenoma, adenocarcinoma, and normal tissue examined by oligonucleotide arrays. Cancer Res $\underline{61}, 3124-3130$

Patel MS, Korotchkina LG (2002): Pyruvate dehydrogenase complex as a marker of mitochondrial metabolism. Inhibition by 4-hydroxy-2-nonenal. Methods Mol Biol $\underline{186}$, $255-263$

Perea J, Lomas M, Hidalgo M (2011): Molecular basis of colorrectal cancer: towards an individualized management? Rev Esp Enferm Dig 103, 29-35

Pino MS, Chung DC (2010): The chromosomal instability pathway in colon cancer. Gastroenterology 138, 2059-2072

Promega: CellTiter-Blue ${ }^{\circledR}$ Cell Viability Assay Technical Bulletin; USA, Juni 2009, www.promega.com

Puppa G, Sonzogni A, Colombari R, Pelosi G (2010): TNM staging system of colorectal carcinoma: a critical appraisal of challenging issues. Arch Pathol Lab Med 134, 837-852

Rajeevan MS, Vernon SD, Taysavang N, Unger ER (2001): Validation of array-based gene expression profiles by real-time (kinetic) RT-PCR. J Mol Diagn $\underline{3}$, 26-31

Rappolee DA, Mark D, Banda MJ, Werb Z (1988): Wound macrophages express TGFalpha and other growth factors in vivo: analysis by mRNA phenotyping. Science 241 , 708712 
Razeghi P, Young ME, Ying J, Depre C, Uray IP, Kolesar J, Shipley GL, Moravec CS, Davies PJ, Frazier OH, Taegtmeyer H (2002): Downregulation of metabolic gene expression in failing human heart before and after mechanical unloading. Cardiology $\underline{97}$, 203-209

Reid YA (2011): Characterization and authentication of cancer cell lines: an overview. Methods Mol Biol $\underline{731}, 35-43$

Renart J, Reiser J, Stark GR (1979): Transfer of proteins from gels to diazobenzyloxymethyl-paper and detection with antisera: a method for studying antibody specificity and antigen structure. Proc Natl Acad Sci U S A $\underline{76}, 3116-3120$

Roche TE, Hiromasa Y (2007): Pyruvate dehydrogenase kinase regulatory mechanisms and inhibition in treating diabetes, heart ischemia, and cancer. Cell Mol Life Sci $\underline{64}$, 830-849

Rustgi AK (2007): The genetics of hereditary colon cancer. Genes Dev 21, 2525-2538

Sieber OM, Heinimann K, Tomlinson IP (2003): Genomic instability--the engine of tumorigenesis? Nat Rev Cancer $\underline{3}$, 701-708

Solomon DA, Kim JS, Ressom HW, Sibenaller Z, Ryken T, Jean W, Bigner D, Yan H, Waldman T (2009): Sample type bias in the analysis of cancer genomes. Cancer Res $\underline{69}$, $5630-5633$

Sommer P, Le Rouzic P, Gillingham H, Berry A, Kayahara M, Huynh T, White A, Ray DW (2007): Glucocorticoid receptor overexpression exerts an antisurvival effect on human small cell lung cancer cells. Oncogene $\underline{26}, 7111-7121$ 
Sugden MC, Holness MJ (2003): Recent advances in mechanisms regulating glucose oxidation at the level of the pyruvate dehydrogenase complex by PDKs. Am J Physiol Endocrinol Metab 284, E855-862

Takayama T, Miyanishi K, Hayashi T, Sato Y, Niitsu Y (2006): Colorectal cancer: genetics of development and metastasis. J Gastroenterol $\underline{41}$, 185-192

Theocharis S, Kouraklis G, Margeli A, Agapitos E, Ninos S, Karatzas G, Koutselinis A (2003): Glucocorticoid receptor (GR) immunohistochemical expression is correlated with cell cycle-related molecules in human colon cancer. Dig Dis Sci $\underline{48}, 1745-1750$

Williams NS, Gaynor RB, Scoggin S, Verma U, Gokaslan T, Simmang C, Fleming J, Tavana D, Frenkel E, Becerra C (2003): Identification and validation of genes involved in the pathogenesis of colorectal cancer using cDNA microarrays and RNA interference. Clin Cancer Res $\underline{9}, 931-946$

Worthley DL, Whitehall VL, Spring KJ, Leggett BA (2007): Colorectal carcinogenesis: road maps to cancer. World J Gastroenterol 13, 3784-3791

Wynn RM, Kato M, Chuang JL, Tso SC, Li J, Chuang DT (2008): Pyruvate dehydrogenase kinase-4 structures reveal a metastable open conformation fostering robust core-free basal activity. J Biol Chem $\underline{283}, 25305-25315$

Yeluri S, Madhok B, Prasad KR, Quirke P, Jayne DG (2009): Cancer's craving for sugar: an opportunity for clinical exploitation. J Cancer Res Clin Oncol 135, 867-877 


\section{Danksagung}

Ich möchte mich herzlich bei allen bedanken, die zu der Entstehung dieser Arbeit beigetragen haben oder mich auf dem Wege unterstützt haben.

Allen voran danke ich meinem Doktorvater Herrn Prof. B. M. Ghadimi für die Überlassung der interessanten Fragestellung und die Möglichkeit, meine Doktorarbeit in dieser Arbeitsgruppe durchführen zu dürfen. Herrn Prof. H. Becker danke ich sehr für die freundliche Aufnahme in seiner Klinik.

Mein ganz besonderer Dank gilt Herrn Dr. Marian Grade und Frau Dr. Melanie Spitzner. Beide haben meine Arbeit sehr intensiv betreut und mich jederzeit konstruktiv unterstützt und ermutigt.

Ich bedanke mich bei Dominic Esposito von den National Institutes of Health für die Erstellung der Vektoren, die eine Grundlage meiner Arbeit darstellen. Bei Herrn Prof. M. Klintschar von der Rechtsmedizin der Universität Göttingen bedanke ich mich für die Durchführung des short-tandem-repeat-Profiling der verwendeten Zelllinien. Ich danke Herrn Prof. T. Beißbarth für die wertvolle Hilfestellung bei statistischen Fragestellungen. Bei Frau Dr. S. Kaulfuß bedanke ich mich für die sehr hilfreichen Tipps bei jeglichen Fragen zum Western Blot.

Ebenfalls zu großem Dank verpflichtet bin ich dem gesamten Laborteam aus Teilprojekt 1 und 2 der KFO179 (Jessica Eggert, Georg Emons, Dr. Jochen Gaedcke, Dr. Peter Jo, Emil Kendziorra, Chang-Rong Lai und Antje Schneeberg) für die überaus gute Arbeitsatmosphäre, die ständige Hilfsbereitschaft bei allen ausstehenden Fragen, die geduldige Einarbeitung in die Methodik, sowie zahlreiche wertvolle Anregungen und Diskussionen. 